\title{
昭和27年度における重要なる燃料関係事項
}

\section{燃 料協会編集}

\begin{tabular}{|c|c|}
\hline 目 & 次 \\
\hline 石炭磄業の趨勢（石炭の需給情勢を & 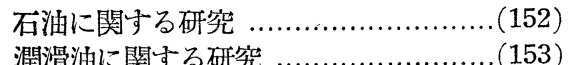 \\
\hline 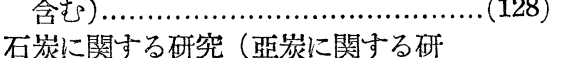 & $\begin{array}{l}\text { 澗滑油に関する研究 ...........................(153) } \\
\text { 內燃機関の趨勢（ガスタービンを含 }\end{array}$ \\
\hline 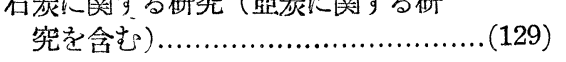 & む) \\
\hline コークス工業の趨勢 & 內燃機燃料の趨勢（ガソリン, ヂエ \\
\hline （I） 製鉄用関係 …....................(133) & ット，ヂーゼル燃料抢よび筒內燃 \\
\hline （II） 製鉄用以外 $\ldots \ldots \ldots \ldots \ldots \ldots \ldots \ldots \ldots . . . . . . . . . .134)$ & 燒を含も) ...................................... \\
\hline コークスに関する研究 ……...............(136) & 汽力発生と焚燒法の趨勢 .. \\
\hline 炭素に関する研究 ……......................(138) & 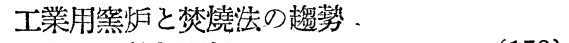 \\
\hline 家庭燃料の䞶勢 ……........................(139) & ( I ) 鉄鋼関係 ……................ \\
\hline 䠅炭工業（家庭用）の趨勢 …….........(140) & （II） 鉄鋼関係以外 .................... \\
\hline 鉄道用燃料（燥炭を含む）の趨勢 …....(140) & 固体燃料に関する研究 ……...............(161) \\
\hline タール工業の趨勢 ……….................(141) & 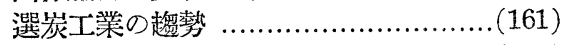 \\
\hline タールに関する研究 ………...............(142) & 選炭に関寸る研究 ‘.................. \\
\hline 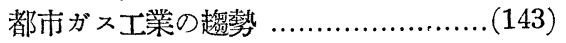 & 熱管理運動の趨勢 ................ \\
\hline ガ ス化工業の䀛勢（地下ガ ス化を含 & 熱管理に関する研究 ……......... \\
\hline 屯) & 動力源の調查開発に関する情勢 ….......(165) \\
\hline ガス化に関する研究 ……...................(145) & 地熱発電の趨勢 …….........................(166) \\
\hline 天然ガス利用の趜勢 …….................... (146) & 原子力利用の趨勢 ……....................(167) \\
\hline 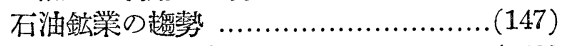 & 燃料に関する会合 …………................(168) \\
\hline 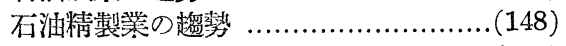 & 撚料に関する規格 …………..............(169) \\
\hline ペトロケミカルスの淮展 …...............(151) & 燃料に関与る新刊書 …………...........(169) \\
\hline
\end{tabular}

\section{石炭㯖業の趨勢}

生産 昭和26年度下期の異状な石炭供給不足の後を 受け, 本年1〜3月の生產量の伸張は著しく，3月に は 455 万 $\mathrm{t}$ と戦後最高の記錄を樹立した。4 月および 7 月には破防法反刘労瞦ストにより推定 28 万 $\mathrm{t}$ の減產 を来たしたが，10月13日に炭労金下大手16神か歷史的 な長期ストに突入したをめ，スト中止指令の発せられ た12月16日に至る65日間の減產量は約 589 万 $\mathrm{t}$ と推定 されている。景気变動の影響に対する石炭生制量の反 応には時間的な逯机があるのを常とするから，一般景 気の沏滞にもかかわらず，予定された行程を順調に進 んだものと仮定すれば，本年度生產量は実績 4,336万 $\mathrm{t}$ に前記の減虍量を加元て，4,900万 $\mathrm{t}$ を突破したも のと想像され，相当深刻な需給の不均衡状態を招来す るに至つたことと思わ机る。出炭を規模別にみると，

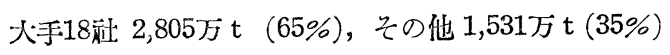
であつて，終戦直後の出炭構成比率に等しく，ストの

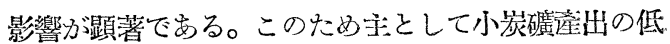
質炭の貯炭が大部分綺融になつた。

荷渡 国队炭総計 4,306 万 $\mathrm{t}$ ，輸入炭 334 万 $\mathrm{t}$ で, 前年度に較べて前者は 280 万 $\mathrm{t}$ の減少, 後者に牧いて は 133 万 の㻼加となつている。これはストの影響も あるが，需要か活潑でなくなつたことが基底となつて いる。产業別にみると增加しているのは電力 $(+25$ 万 t) とセメント (+19万 t $)$ だけであつて，他は鉄鋼 $(-85$ 万 $\mathrm{t})$ ，化学工業 $(-51$ 万 $\mathrm{t})$, コークス $(-34$ 万 $\mathrm{t})$ ，ガス $(-13$ 万 $\mathrm{t})$ ，造船造機 $(-11$ 万 $\mathrm{t})$ とす べて荷渡が減少している。これに反し，輸入炭は鉄鋼， ガス、コークス，電力等の部門で增加している。中で

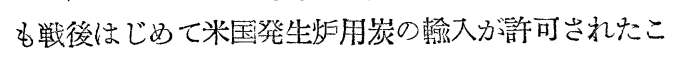
とは，ストに対寸る祭急措置であるとはい它注目に值 することである。本年度にはい恋代一船も入着してい ないが，明年早々第一船が入着するはずである。また 重油の進出に電力その他の㡾業ならびに小口の需要に 
対して著しく，石炭に換算すると約 300 万 $\mathrm{t}$ となり， 石炭はこれだけの荷渡を失つた勘定になる。夏場の貯 炭は 8 月には坑所港頭 263 万 $\mathrm{t}$, 大口消費者 584 工場 の貯炭 363 万 $\mathrm{t}$ 計 625 万 $\mathrm{t}$ に昇り著しいものがあり， このため歴史的な長期ストによる石炭不足子相当中和 された訳である。とにかく炭磺界にも関連產業にも大 きな影響を与えた炭坑ストも，終結後1ケ月たつかた

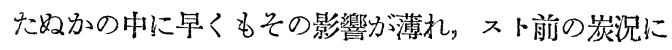

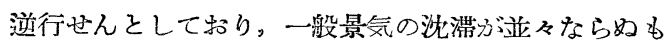
のであること窥える。

その他 高炭価問題にういては終戦以来種々の論議 が重效られてきたが，朝鮮事変の勃発と共に一封特需 景気の蔭に隱れてしまつたようにみえた。しかるにそ の後匡際情勢の変化と共にわが国経済自立目標澾成の ため緊急解決を要すべき問題として再び国内の世論が 高まつてきた。これをチェックする一手段として外国 炭と重油の輸入をさらに盛んにせよと提唱する向きも あり,現在幾分その影響が現われていることは確な゙が, 外貨の枠も方つて，それで万事が解決されようとは思 えない。もしろ供給過剩に急速に向いらつある現在, 炭磺に対し合理化に必要な資金の獲得を不可能ならし めるので低炭価にはならない。問題解決に対する措置 として本年行われたものは，3月に苼業合理化審議会 石炭部会の答申が発表されて合理化の途力゙期らかにさ れ，4月にはドイッのフリッチェ博士が炭礦界の招き により来朝し, 豎坑開発方式や経営管理の技䘕に関し 有谷な助言を与兄, 政府も㹂坑方式による炭砝の若返 りに重大な関心を寄せ，世界銀行に対与る融資の要請 を行らべく計画し，経理面では稅制の改正と炭住借入 金の処置の問題が解決され，今な⿰ 480 億门に及心゙外 債の処理に一道の光明が見出されるようになつた。

\section{石炭に関する研究}

近年各国に沶いて石炭が資源として重要なものであ ることが再確認されたため，これに関する研究はます ま寸旺盛となつている。その傾向としては前年に弓続 き分析怙よび試験に関するもの，なかでも酸素の直接 定量, 組織成分に関なるもの, 溶㓮抽出特よび吸着な いし湿潤熱による檴造研究, 酸化に関与るものなどが 多い。

分析に関するもののちち，水分については Bryson 氏らは K. Fischer 試薬による定量法，また及川浩氏 は誘電率拉よび誘電損失をもつて測定する方法につい て述べた。畭燥法による從来の水分測定法に関する 批判としては，Kreulen 氏が吸着実験と関聯して $105^{\circ} \mathrm{C}$ とい5 乾燥溫度は多水分炭では低すぎるとい
い,また Deinum 氏らは anhydron による吸着量 と比較して $\mathrm{N}_{2}$ 気流中ならば $150^{\circ} \mathrm{C}$ て短い乾燥時間 で差支えがないと報告した。灰分については，Endell 氏は，褐炭の灰分について $\mathrm{CaO}$ か㳘分にあればよい が $\mathrm{Al}_{2} \mathrm{O}_{3}$ 中 $\mathrm{SiO}_{2}$ が多いと $\mathrm{SO}_{3}$ が失われ，立乾溜 時間方短いと $\mathrm{Fe}^{++}$, 長いと $\mathrm{Fe}^{+++}$が多いと報じ, また Tomlinson 氏らは灰分定量用の燃燒皿の影響に ついて述べた。灰分と石炭中の無機質の量との関係に ついて, Schuster 氏が Thiessen-Holthaus の方 法は $\mathrm{Fe}$ 炭酸塩があると低く出るから $\mathrm{CO}_{2}$ の定量が 必要であるとし，Brown 氏らは無機質 \%=1.06× 灰分\% +0.53 全硫黄\% $+0.74 \mathrm{CO}_{2} \%-0.32$ で表わし 得るとし，また Georgiadis 氏はいわゆる灰分補正率 として 1.070〜1.086 の値を報告している。灰分とは 少し異るが Leer 氏は電気炬による灰の融点測定方法 に関し報告した。揮発分については Licznerski 氏が 石炭にガス化漳を混合すると計算による揮発分より減 少すると報告している。元素分析に関するものとして は, Wildenstein, Bastick, Barbe, Schröberl, Gruérin ら各氏が，それぞれ石炭中の O を直接定量 する方法に関して発表した。これらの諸氏は, 純 $\mathrm{N}_{2}$ ま たは $\mathrm{H}_{2}$ 気流中で石炭を高溫で熱分解し, 酸素は $\mathrm{CO}$ の形とし,次ぎに $\mathrm{CO}_{2}$ に変え適当な吸收滆に吸收させ

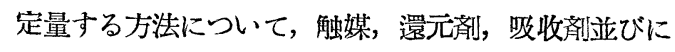
灰中の Oの補正などについて試験した。Radmacher 氏らは N の定量に関し Dumas 法の改良について報 告した。S については, Davies 氏らは Strambi 法 とェシュカ法とを比較し前覩が後者より少なく出るの は前者は高溫で処理するため熔融して水で充分浸出し 難いためであるとし，また Radmacher 氏はェシュ カ法の改良, Elchick 氏はボンブ法の改良について報 告している。Pについては Ellington 氏が新方法を， また Wnekowska 氏がキールダール法の改良につい て述べている。Gupta 氏は Meulen 法でインド炭中 の $\mathrm{Cl}$ を分析し, 全 $\mathrm{Cl}$ の $35 \%$ は有機質のものであると 報告した。発熱量に関しては Lange 氏が測定の際の

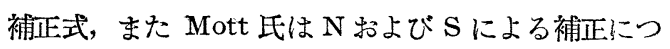
いて報告している。Aranda 氏らは発熱量測定方法と その結果並びに工業分析との関係式, Bertette 氐は Belcher-Spooner 法による商発熱量の測定について 報じた。さらに Bull 氏は濠州褐炭の発熱量について 述べている。Coppens 氏らは工業分析，無機質中の $\mathrm{CO}_{2}$ 岁よび炭酸塩, $\mathrm{S}$ 関眑物質の定量法について報 告している。城 (溫) 氏は石炭粒子と単位面積の液面 との接着量を知り得る装置, Dulhunty 氏は実験室用 
Combustibility 測定裝置, Aranda 氏住低乾裝置, また Joumier 氏は室溫における $24 \mathrm{hr}$ の酸化も知り 得る精密な dilatometer 考案した。さらに Orning

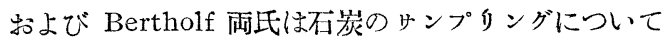
報告している。

組織成分に関するものとしては, Seyler 氏が油浸 レンズで研磨面を䚁察し，その refractance を10段 階に区別しその最当高いものを Fusain とした。この 度合は炭化の進むほと，なた熱処理の淮もほと高くな ると述べた。Mtikherjee 氏もなた refractance を測 定し，空気中のそれは油中のそれ $\left(\mathrm{R}_{\mathbf{0}}\right)$ と同样に炭化

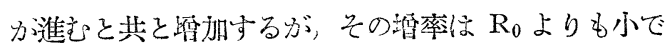
あり，立た部分燃矢した石炭中に $\mathrm{R}_{0}=7.4 \%$ の $\beta-$ coke と称する新成分を見出した。ざらに Seyler 氏 は綠色光線の反射により, 石炭中に 10, コークス中に 3 成分の植物からの变質物是認め, 炭化の進むと共に また乾溜力淮もと共と規則正しく変化すると远へた。 Kardoss 氏队常綠樹や术皮に存在したと思われる xylitic, xylovitritic 拉よび pelibliniticな成分を適 量に含さハンガリ恶炭は粘結することを示した。 Horton 氏は手撰およで比重によつて频炭を徹底的に 分離し C 84.6-88 6\% の石炭の比重が最小であるこ とを見出しこの比重を境として maturing の稼式 が異ると流べた。Duparque 氏はモロッコ無成炭の組 織成分, 偏光に上る钼察から無哂炭抢よび石炭中の無 定形部分は酸化剂および有袎溶媒により 分別される

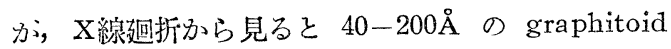
micelles からなると考元ている。 Orenshko 氏は組 織成分と着火溫度との関係を調べ, 長焰炭のフヂ,ト はビトリットよりも着火溫度力嵪く，コークス炭ては この逆となり，フヂ,トは乾溜した不炭とほぼ同じに なると報じ，またVeseloostii 氏ら斗牛無煙炭につい

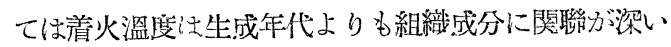
と述べている。この他各地炭の組織分析結果は数多く 発表されている。

吸着ないしは湿潤熹に関するものとしては， Marherbe 氏市 Freon-12や $\mathrm{C}_{4} \mathrm{H}_{10}$ なとの低溫吸着 とメタノール昅着を比較し，後者は前者に比し吸着と 考えると著しく人きい內㓠表面積を与えることから， 後者は吸着ではなく溶解または稀㹞と称寸べきもので あ万弓と述べた。Lecky 氏ら网様の見解から B.E. T. 法で內部表面積を測定するのは無理であると述べ ている。これに反し，Berkowitz 氏は，N および A の等溫吸着から計算した內部表面積とメタノール吸着 から計算したものとの間の著しい相違は, 後者は有効
表面積よりもむしろミセル表面積を表わすものとし て, 南 Hemisphere 亞炭の湿潤熱を測定して，その 內部表面䖽を叮算し，Bangham 氏らの示した石炭ミ セルの寸法は正しいと主張している。Dryden, Drese1 氏らはェチレンチアミンとメタノールの吸着微分熱の 比は全湿潤熱の比と等しいことから，これらの溶媒の 浸透限界はほほ等しいと考完，また耐者の微分熱の相 違は前者力化学的, 後者は物理的な方式によつている ためと郝告している。Dryden 氏は $25^{\circ} \mathrm{C}$ のチレン ヂアミン㔭着は $7 \%$ 以下では化学吸着, それ以上で物 理吸着, さらに溶解㞧よで稀釈の 3 段階からなると推 定し，この反応は重合休と溶媒の系圭考元るよりも膠

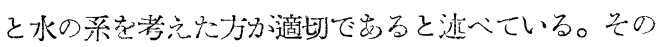
他, Fttinger E只 $\mathrm{CH}_{4}$ 吸着と水分との艮係, Khodot

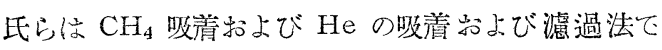
porosity をしらべ, 平均sorption volume 55\%, filtering volume $45 \%$ を得た。Sidello 氏らは下シレ ジャ䍝の $\mathrm{CO}_{2}$ 吸着, 松本敬修氏法坑门ガスの吸着お よで吸着熱について郝等している。

溶郩技妍に関するもののうち， specific solvent 䛧用寸るものとしては Brooks 氏方泜炭化度のエチレ ンヂアミン抽出溶夜をペーパークロマトグラフで分別 する試験を行い mobile phase として10\%ヂアミン

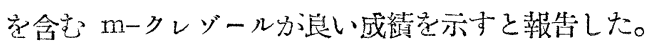
Dryden 氏蜎年に引続きェチレンチアミン抽出物を 調へ，その組成は国体の石炭と大差なく，むたその性 状は抽出中および欲ではコロイド的であるか㸮子量を 測定吉ると 300〜400であり，この間の消息か不明で あると远べている。これに刘七 Kann 氏らは電子影微 鏡ないしに超顕微鏡でコロイト的粒子を見出し得ると 報告しているふふ，Wyne-Jones 氏ら就よび及川浩氏ら はピリチン抽出物を電子顥微鏡下て観察しそのような ものを発見し得ないと報告している。non-specific solventに関守るものとしては Jencis 氏か燃料比 1.2 13 のRosa 炭をベンゾール抽仙し, さらに石油

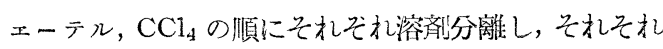
に可溶なものほと重合度か低いこと，末た赤外線スペ クトルによる周辺の基新よで芳香族性には変化か活る カ核模遮には大差务ないこと，コらにフミン酸につい てその酸性基は主としてフェノール型てあると推定し た。坂部孜氏は夕張炭のベンジール抽汕により得た油 状ビチューメンから結晶する物質を分離し，紫外スペ クトルその他で，このものは 411-ヂメチルピセンで あると推定した。Srikantan 氏らは南印度 Ascot 崖 の xylene 括出物の性犋，Varier 氏京 Warkalay 亞 
炭中のレジンの性質について報告した。また Silvig 氏らは米国に淤けるモンタン繒の不足状況々関聯し亞 炭中のモンタン蟛について論じ， $4: 1$ ベンゾール，ェ タノール混合溶用による抵出試験について報告した。 Destructive disintegration に関するものとしては， Orchin 氏らは Pittsburg 炭をフェナンスレンで技出 し, さらに溶㓮分離して矢の性状を調べた。まだ゙ン ッ゙ール環 3 環以上の溶剮の效力を比較しフェナンスレ ンのごとく angular 配置のものはフルォレンのごと く non-angular 配置のものより强力であると速べた。 Novikov 氏はアンスラセン油で不炭を抽出し，非粘 長焰炭でも强粘炭でも抽出率か高いことから，粘結性 はむしろ反応中に発生寸る低融点物の量に関係し, 强 粘炭てはこのものが加熱により急跨与ると速べてい る。粘結性と溶剤抽出については舟阪氏らが粘結性の

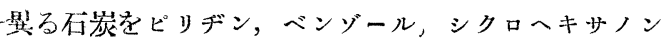
等で抽出し，その抽出率はピリデン以外は粘結性と比 例与ると報告した。

酸化については，Chérean 上は $160-270^{\circ} \mathrm{C}$ で不 炭老酸化しその重量変化より中間で重量か㵊大值に迋 士る点があり，これ酸素の添加による重量恓と之れ に続く分解による重量減の反応考考克ると說明できる と述べ，石炭中の巨大分子の 2 重結合に $\mathrm{O}_{2}$ 力固定五 れるといら機權を考えた。本田英昌氏は燃燒と関聯し

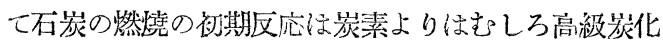
水素の燃燒機構を考えるべきであると俩じ，Oreshko 氏らは $270-340^{\circ} \mathrm{C}$ で加熱すると低溫て酸素と complex 造り易い石炭中の最小重合物は失われるから， $390-400^{\circ} \mathrm{C}$ で高溫 complex の生成分急增与るか; 着火溫度には低沸点揮発物は 無関係で，390 $400^{\circ} \mathrm{C}$ の処理後の着火溫度の急上昇は熱に不安定なものか脫 却するためであり，430〜 $40^{\circ} \mathrm{C}$ の処理で着火溫度の上。 ろのは O-complex の生成率が大となること怙よび 石炭か熔融軟化し結晶化するためで心るとした。 Constantinides 氏浊石炭の風化について BunteBruckner の方法でしらべた結果, $50^{\circ} \mathrm{C}$ 以下では $\mathrm{O}_{2}$ の消費量 $x$ は日数 $T^{\prime}$ と Schmidt-Elder の関係式 $\left(r=C T^{\varepsilon}\right)$ が成立すると報告し，Oreshko 氏は揮発 分と着火溫度並びに酸化反応をしらべ, 全体とし 一石炭 $+\mathrm{O}_{2} \rightarrow \mathrm{CO}_{2}+2 / 3 \mathrm{CO}+5 / 2 \mathrm{H}_{2} \mathrm{O}$ となると述べ， Voselvoskii 氏らは着火溫度と自然発火の関係，また Schein 氏は石炭の自然発火の初期発熱は湿潤熱に上 ると述べている。Roge 氏は Kreulen 氏のフミン酸 曲線から本法は酸素に対する親和性および分類に使用 し得ると報告している。
溶液酸化に関しては, Howard 氏らはポカホンタス 炭を $\mathrm{NaOH}$ と水の存在下で加圧加熱酸素酸化した場 合の生成物の內で水に可溶の polycarboxylic acids の核構造をしらべ，この核はベンゾール1環よりもさ

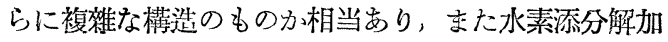
生成物はかなりのOを含2 phthalan 類に類似してい ると速べなた別にアルカリ法と确酸法の隻劣を比較 し, 硝酸法は低溫で行い得るが， $\mathrm{HNO}_{3}$ の回收，腐

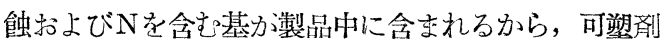
の製法としてはアルカリ法か良いと主張している。こ れに反し Grosskinsky 氏は不炭の硝酸酸化に及ぼす 炭種，組織成分，物理牰よび化学的前処理，粒の大き さ, 硝酸の濃度, 触某, 溫度, 圧力なとの影響につい て郝告しアルカリ法より㗂酸法が良いと報告してい、 る。Duuren 氏らは南阿炭を $1: 1 \mathrm{HNO}_{3}$ で分解し 溶用分離および覓空蒸溜によつて分別し succinic acid 拉よび無水物， phthalic acids 抢よび無水物， ピクリン酸および黃色粘稠夜を得た。Kinney 氏らは 确酸酸化による再生フミン酸の分子量を測定したが， 高度に会合しており溶剤により分子量は一定しないこ と，またチル化によつてーOH基の化学的性質をし らべ，加水分解に抵抗を示すメトオキシ基を造るーOH は元来フェンール型のものてないと速べた。この方面 では檤口耕三氏らの研究か洮る。

水素添加分解に関しては, Falkum 氏らがスピッべ ルら゙ン炭について試験を行い，可溶および揮発性の物 質か生成与る反広は一次反応と見做せると報告し，前 記 Orchin 氏らは $0.6 \%$ 程度の微弱な水素添加により コークス化性を著しく璔進し得ることを迹べた。これ については Nadziakiewiz 氏劣よび Kukharerko 氏 ら斥 $167 \%$ 程度の水素添加により同様の效果を認めて いるがここれらのことは日本の扮いてほ 10 数年以前既 に本誌上に渐村唯治氏分研究成果を発表している。

爇分解に関しては，Breger 氏らは石炭およで関聯 物質を熱分析し，リグニンの低溫における熱特性は泥 炭では不明瞭てあるか監炭では明らかになり無㖶炭に 至り消失し，七ルローズのそれは歴青炭以上では消失 することを示し，丹野氏は熱天科を倬用しそれらの熱 分解溫度定研究し, セルローズは $270^{\circ} \mathrm{C}$, リグニンは 310 360 C で主として分解寺るが，フミン酸は顕著 な分解点かなく，また石炭では $250 \sim 270^{\circ} \mathrm{C} ， 300$ $340^{\circ} \mathrm{C}, 370 \sim 500^{\circ} \mathrm{C}$ のつの主要分解点があり, 前 2 者は炭化か淮索を共に上昇与るか汾解率は減少し, 後者多炭化か璡导と高くなるから分解率は歴青炭が最 人であると郝告した。Gillet 氏ら女堂素気流中で熱分 
解し，残留物を顕微鏡下て観察し，リグニンと脂肪炭 から生成したものは類似し, 溫度 $105^{\circ} \mathrm{C}$ では木炭の $8 \%$ の重量減中 $1.3 \% か ゙ ~ \mathrm{H}_{2} \mathrm{O}$ で残りは glyoxal, glycolic aldehyde であり，不完全な熱分解はごく 低溫でもはじまるか稘の熱分解は $360^{\circ} \mathrm{C}$ 以上て起る そ沭べ, Nadziakiewicz 氏らは石炭の熱分解溫度は 揮発分に逆此例寸るが, 强粘結炭より若い石炭ては $O$, $\mathrm{N}, \mathrm{S}$ などの含有率の高いほと低く，またそれ以上の 石炭ではまり影響がないと述べている。Poncinous 氏は石炭が芳香族核の周辺に長さの異る側鋇を有する 巨大分子よりなると考え，ま翟最初の熱分解で粘結炭 は粘度の高い夜状となり，400〜 $600^{\circ} \mathrm{C}$ でガスおび タールを発散して半成コークスとなり，次ぎに 700〜 $750^{\circ} \mathrm{C}$ で $\mathrm{H}$ 呿よび $\mathrm{OH}$-基の離脫により線状部分が

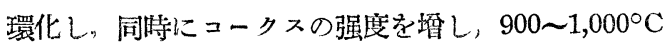
で無定形のCが金属的なものに変わると論じ，Lahiri 氏は石炭を $\alpha, \beta, \gamma$ の各相よりなるイッゲルと考穴， 分散媒分熱によつて性質を変化するかまなは失われて 凝集し，二次的結合か一次的なるのに変化することに よつてュークスの强度か㘧すと說明した。Krevelen 氏らは石炭の熱变化を反店速度から考察し polyethylen, polystyrene および polyindene なとのモデル 物質と比較している。

X線迴折によるものとしては前記 Duparque 氏の 他, Kasatochkin 氏らの研究がる。主なわち, 石炭 については炭化が淮むと次第に迴折写稘は明確になる

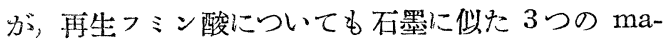
ximum, を示し，炭化が進むとベンゾール核の規則正 しさが增すと思われまを peripheral に現われるホ ケは周辺の基によると考えられる。芳香族核の縮合度 を示守と考えられる“C : H 比はこの迴折現象と平行 しており，計算によれは縮合環の数は1から10以上に 変化し，また核が発澾すれば側鎮は減少すると述へ た。Georgiadis 氏はX線迴折, 雷気伝導度および酸 処理で石炭の石墨化を研究し， $750^{\circ} \mathrm{C}$ 以下ではほとん と石墨化せす 溫度が高く, 加熱時間方長く，加熱卒 方小さくまた酸化の遅い方か石墨化し易い。炭質とし ては揮発分が多く, 膨脹率の高い力か石墨化し易いと 報告した。

松山英太郎氏は沖山五段炭の透過および迴折写傎に よつて乾溜中の変化を調へ，石墨クリスタリトは $700^{\circ} \mathrm{C}$ で縱横両方向に階段的に成長し，立た石炭中の 鉱物質は溫度に上つて变化することを示した。井上勝 也氏らもをた特に本邦炭の熱変化の外国炭と異るとこ ろを迴折写縝により研究した。
不炭中の硫黃については，Fuchs 氏からおよびその 化合物の自由エネルギーから石炭の熱分解中の変化を 考察し，Mainz 氏は浮沈試験で分別した石炭中の S の種類拉よび乾溜中の变化について報告した。また Kreulen 氏は酸素が少なく S カ311\%も市る Rosa 炭 について興味ある報告をした。すなわち，この石炭は 揮発分拉よびタールか多く refractance は低くこの 点では低炭化度てあるかう，粘結性，賦活ェネルキ，着 火点はいずれも高く，水分は少なく，これらの点では 高炭化度である。Sの大部分は核內に女り，再生フミ ン酸は $8 \%$ のを含み，フミン酸および石炭の $\mathrm{H}_{2} \mathrm{~S}$ 吸着量は異状に多いと報じている。Duck 氏らは石炭 中の Asは arsenopyrite として存在すると促来思わ れているが，稀塩酸にわすかしか溶出されないところ から有機物と結合していると考点られると述へた。

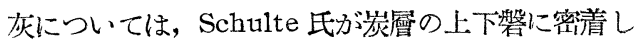
ているいわゆる“angebrannte” (焦) 炭こついて研 究し， $\mathrm{Fe}_{2} \mathrm{O}_{3}$ 含有率が $30 \%$ 以に及ぶことからこの 成因は地質变動よりはもしろその起源に基つくもので あろろと推論した。Donnelly 氏らは石炭巾の $\mathrm{Fe}_{2} \mathrm{O}_{3}$ は $\mathrm{CO}_{2}$ に刘する反応性を唔すと述べ，Edgeombe 氏 らは工業に特ける灰およびクリンカの問題を徹底的に 究明し惡。

近年本邦においても話題の種となつている石炭中の ゲルマニウムについては，Headlee 印らは西バーチ ニヤ炭の pyritic, organic および全 $\mathrm{S}$ の分布と共に Geを分析し，Geか灰分の少ない部分に集中している と報じ，Vistelius 氏らは Ge 0 001\% 以上の石炭に ついて灰分と $\mathrm{Ge}$ 含有率との関係を調へ， $\log (\mathrm{Ge} \%)$ と灰分\%とは逆比し Ge は有機物と結合していると 迹べ，Aubrey 氏当また英国炭の Ge 分有を調へ有機 物と結合しているという見解を下し，本邦に执いては 稻坦勝氏方本邦炭の Ge の分布, 燃燒およで乾泖时の 变化を調へ，一般に炭化度の低い存炭に多く日つ灰分 の少ない輝炭部に集中していると報した。この他世界 齐地の不炭中の $\mathrm{Ge}$ の調查報告は数多く発表されてい る。

総括的な炭化作用，構造，分類なとに関するものと しては Romwalter 氏は石炭の起源物質としてッグ ニン, 樹脂。脂肪酸, 野を考穴, 緩曼な酸化でHか減 じCか筫すかこの反応が “Inkohlung”てある。し かし $\mathrm{O}: \mathrm{H}$ か 2:1 を越えると粘結性は隇するから， 結局石炭中に不融の huminoid 成分と易融の bituminoid 成分がでさるか，この適当な割合かコークス化 性に必要であると迹べた。多和田寬氏は溶㓮抌出試験 
から炭化は石炭の主成分てあるフミン質の重合と共に ヒチューンン型化することてあると述へた。舟阪氏ら は人造石炭に関する実験並びに石炭に対寸る試験結果 から，七ルローズ炭より環状䆏造のものが得られる こと，また示性分析てリグニンとして定量されるもの か生することを示し，さらにフチ，卜は山火事，腐泥 炭は水生植物, 石油は蛋白質を根元とするのか挼当で あると考皃た。

Howard 氏は $\mathrm{C}: \mathrm{H}$ 比，分子蒸溜，溶纺抽出，水 素添加，酸化なとの結果から，石炭は主として環状構 造を有しここれらの操作による 環状化合物の收率は degradation process か何度の盗度で起つたかに係 るものでると迅べた。Krevelen 氏は，瀝青炭の H：C および O : C の関係を図示寸れは, 組織成分, 炭化の度合, 乾溜, 酸化, 水素涯加等の変化の模嵄, 構 造の変化等を知り得, これに密度(むたは比容積)を加

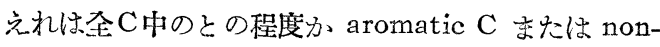
aromatic Cであるか察することか可能てあるとした。 Francis 氏は元素, 工業, 示性, 組織等の各分析, 乾 溜，快炭化，物理等の各試験を含も 7 項目の分析試験 を挙げここれらの結果によつて英国炭を新しく分類す る必要かあることを論じている。Fuchs氏は石炭の根 源, Sherman 氏らは石炭の根源, 用途, 探掘, 選炭 の関係を茺べ，Gunn 氏はホイラ用炭としての適性基 凖性質を試験している。

その他，P1con 氏は17〜59年前に探掘した石炭と今 日の同じ炭層の石炭とを $1,000^{\circ} \mathrm{C}$ て乾溜し，ガス

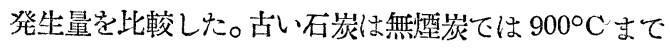
はガス発生量はわすかに少なく，それ以上の溫度ては わすかに多く，カス㠶化合物は多い場合がる。 Trifonov 氏らは石炭に10分間 $20 \mathrm{t} / \mathrm{cm}^{2}$ の圧をかけて 実験し，その結果 $7 \%$ 油状ビチューメンか減少し，固 形七チューメンか崸加したと迅へている。炭塵爆発と 関係与る問題としては房村信雄氏か揮発分の発生状 况, その量および質について，佐藤与助氏らは粉碎過 程, 田中正男氏らは石炭粒積の熱伝導率をそれそれ研 究した。この他 ultra clean coal または脫灰につい ても, Crawford 氏らの紹介就よびその他の諸氏の研 究溌表急机た。

\section{コークスエ業の逷勢}

\section{I 製鉄関係}

\section{1 概 況}

初頭は前年に続き各匡軍拡の急速化により $1 〜 2$ 月 は市況は活潑てあつたか，米国軍拡計画の变更とド几 不足に基づくポンげ域の輪入制限て 3 月上降壮不振を
続け，輪出の減少により既契約原燃料の高価の圧迫を 減すため原料炭の值引交步力始められた。国内炭に打 いては炭価引下げ交涉は業界主目の中に数回にわたつ て牰り，一方輸入然料は，海上運貢の低下なとのため， その抑制にもかかわらす既契約のものか－時に入荷 し，高価のまむて使用を迫られる状况て，銑鉄は減產 対策をとり，八幡洞岡 $500 \mathrm{t}$ は 7 月30日止を 5 月31日 に早め, $1,000 \mathrm{t}$ 火大 8 月 1 日を 12 月 1 日に, 日本鋼管 川崎 $600 \mathrm{t}$ 多 9 月11日皇12月15日に火入れした。ちよ 万と米国鉄鋼ストが 6 月 3 日より 54 日間子あり，多少

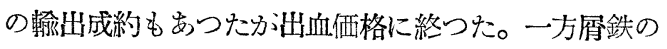
枯渴て平炬湿銑率の引上は銑鉄価格の引下けを强いら れますます作業合理化，品質管理の译力か必要とな つた。10月17日より12月16日まての62日間の日本の炭 礦ストて，强粘結炭の貯炭使用を70〜80\%に引上げ，

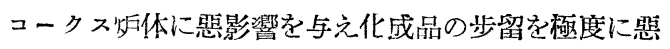
化さぜた。

\section{2 原料炭とコークス作業}

强粘結輸入炭はほとんと米炭と印㢃炭て，一部オ1 ルコークス $2 \sim 7 \%$ ，カナタ炭 $10 \%$ ，土威炭10\%ぐら

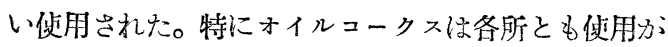
漸㳄減つてきたこと，印度炭の灰分か $18 \%$ より16\%に

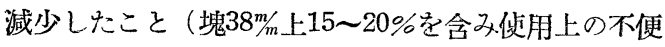
がある）は注目すべきでる。国内强粘結炭ては，北 松炭力八幡, 広畑, 日本鐗管, 三菱化成（八幡，小含 向）で 5〜10\%使われていたか，高価のため配合はそ の6割に減少したが，炭硍側の痛烈强硬な要望て再び 8割程度むて引上げられた。な滏石ては油戸炭(灰 分125\%) $5 \%$ くらいの配合をすつと続けている。輸 入粘結炭てはちよ5と炭礦ストの10月に塔路炭か日本 鋼管と広畑に一船つつ入港し，価格も安く，品質もよ く賞用された（灰分卡れそれ8 5\%と 125\%)。むた米 国の粘結炭力八幡と広烟に昨年末上り漱次入港し，ス 卜後の不足を補い期待されている。次きに国内粘結炭 は順次滛汰され、大手筋の高級炭に技きか元られ，銘 柄も20種程度に減り配合上便利となつたが，価格は佂 然割高て今後の対策か問題てある。

コークスの品位として，灰分は八幡，三菱化成 $145 \%$ ，広畑 $12 \% ，$ 釜石 $11 \%$ ，室策 $12 \%$ ，日本鋼管扇 町 $115 \%$ ，大宜 $125 \%$ ，東京瓦斯末広 $15 \%$ 。潰裂强度 かその高版能力以上に硬く 90〜93\%を示すのは割安の 輸人炭を多量使用するためてある。水分はたいたい2 〜 4\%を示吉か，塊状のみを探るのと広烟のことき自 働ッンプラーて 1 in以上を全部とるのとは後者の方か 水分多く，小塊に水分の多いことか広烟にて確認され 
たことは品質㷮理上注目すべきてある。一般に自㗢め ンプラーは八幡尔よび富士各所て研究きれ，見るべき ものか脑る。

コークス作業上特て変つケことは，広烟て第一高炉 改修中（10月15日～12月25日）過剩コークスを第三炉 (75基) の蒸込減流法て生する 20〜25本/日 窒出でが ス用コークスとし販買したか，水分少なく硬い点て好 評てあつた。さた將来子想されるものに，中山製鋼第 二高所 $420 \mathrm{t}$ 用の黑田式55基恃修理完了，昨年末に煙 突乾燥に入り末年 3 月 14 日に開始予定, 尼鉄の $350 \mathrm{t}$ 炉用日鉄式 41基仗 3 月25日の予定て子手入隻めてい 万。川鉄千禁 $500 \mathrm{t}$ 绉用新ホットー54基 2 団の弓ち北 侧は11月15日，南侧20日より沵瓦積きはじめ，昨年末 て40\%完了，本 6 月15日儿㨨業子定でる。聞くとこ ろては小倉止再で一炉計画むり，現在稼動中の高炬か

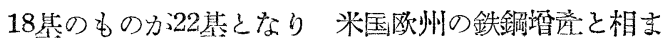
つて競争激化ふ䈍される。

3 コークス製运没诵

コークス炬体ては日本眮管第一师（650t/日）68基コ ッパース循還式束西雨作団か12月18日と本年 1 月 7 日 に六れそれ操業を始わ，川鉄千葉の新オットー54基が 筑所中，釜石第三25基は日鉄改良型て10月30日開始し たか，一般に特经激らしいるのはない。附属設備ては

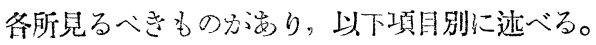

洗篇 釜石て F.W 式浮選 $10 \mathrm{t} / \mathrm{h}$ 为 311 月 20 日上り 稼動した。八柏は洗炭機用空気室の二段膨脹を行い，

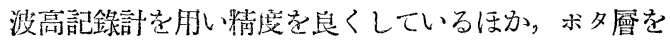
一定にし精炭の吸込を防止するなめ，一槽ホタ学二慒。 に入れ，且つ二槽 $20 \mathrm{~mm}$ 以下求及を一槽に入机て步 留向上をねらつている。

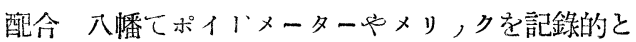
し，東口て灰分の迅速分析を多数行いコークス灰分の $\bar{R}$ を 035 瑅度に向上させ，脱水慒前に㧓動節を設け 脫水效果を50\%向上せしめた。広畑，釜石纴可至減速

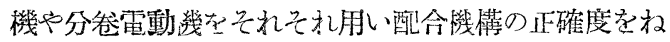
らい集備中てをる。

粉碎 八幡法鿉㢣式 $50 \mathrm{t} / \mathrm{h}$ 索試験中，また印辰炭

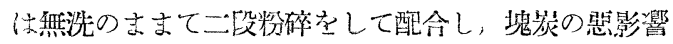
を除くように努力している。

装入 裝入車に㧨動器を取付けているのに，八幡，

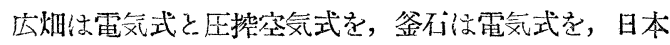
鋼管は圧控空気を探用するほか別にラーブル式を室闌 と同様用い，三菱化成は空気式を用万。

裝入炭槽 炭取出しを容易にするな揗動器を取り 付けたのに八䊩，日本鋼管が㐫り，出口ら゙ート開閉に
空気ンリンダーを取付けたのに，三菱化成，八幡，日 本鋼管がある。広畑が圧控空気吹込みにより炭取出を 行つているの恃記ず゙きでる。

押出機 管の屝取りを電動て行つているのに釜石， 広畑，八幡，日本鋼管かあり，空気作動て行つている のに広畑，釜石があり，日本鋼觜ではレベラー口屝の 開開を渾転室より行らよう試験中てある。返り炭処理

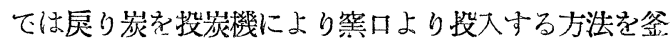
石てはじめ，八幡もこれを探用している。

コークガイド 空気作動による屝開閉には広畑，室 蘭があり，八幡は電動式てある。ガイド格子の出入す るのに室蘭，釜不，広甽がり，広畑保下部U型部の

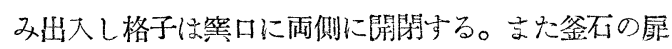
閒の締めゆるめに特殊ボール入クラ，チを用い，小型 モーターて自偅化したのは註目寸べきでる。公幡山

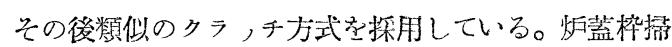
除機は釜石，広畑，室蘭，分幡なとにあり，改造によ

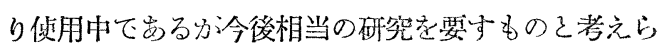
れる。

輁出信号裝置 光の反射学利用しガイド侧より連絡 与る方法を三菱化成方始嬸もこれを探用，広畑 は消火果，カイド，押出党一線に絡ぐ三点接触器を隼 備中てをる。

上昇管ダンパー自㣫調整 鉒石て始められ広畑て改 良されて效果茥もけ，八幡もこれを利用している。

炭化等速絡孔 留入時のガスか炑蓋より噴出するの を防止するため隣接案の頂郆と連絡することは室闌て はじめられたが，こ扎を庆畑て改良し，炬体內に牤さ め，穴の効果分化成品に及ぼ寸影響を研究中でる。

自働消火裝置 広畑て最初成功したのふ刺激とな り，八幡，室蘭，釜不，日本鋼管なとてそれそれ独特 な方法を採用し、コークスの水分蜮少するとともに バラッキダ少なくなつた。な持室策は神給水の自衝化 て后に隇つた。

コンベアー遠隔制御 釜石, 窒闌, 日本鉱管て探用, 釜石ては警報とッウンチングを用い機權を改良してい る。

デカンタータール中の粕を自働的に取出すのを窒 蘭て探用している。

以上のと抢り, コークス工業の合理化は，熱心に進 められているかッこれてはいまた充分とはいえなく， 外国に負け妙らに努力するとともに，石炭と鉄鋼は 相たずきえて協力進步して行きたい子のてある。

\section{II 製鉄用以外}

上期の需給状況 
昭和26年の供給不足は同年末ごろには供給量の塭加 から䌅和され，需給とんとんの状態となつて 27 年を迎 光た。

初期には需要而に打ける減退の样子はなからなか， 都市カスの最盛需要期てあるためコークス生產は当然 㙁加し，需要を上廻つてきた。春ころから硫安工業は 生産手控穴，ま民石灰空素工業はォイルコークの翰大 品かそくそく入荷与るほか，前年度の供給不足にかん か2所要ュークスの早目のスト，ク手当成から買入手 控えとなり，肥敞向けは需用不振であつた。鋳物用も 再軍備，電源開発閔係なとによる機械工業の需要堛期 待はすれによりっかんはしくない需要てあつた。 下期の需給快況

本期の前本はカスの不需要期て，カ ス事業からのコ

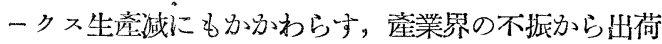
减起し，滞貨は次第に漂加与るに至つた。26年に比し 渚しい変りようて；日本の経済基盤の贱芑をそのまま 反胦してきた。需要の減退は全股的には価格の問題て なく、ニークス午のものの需要减に其つくものてある
か，肥料向けのものについては，硫安用はコークス法 の探算上の関係から，また石灰窒素用は輸入オイルュ 一クとの価格の刘抗上，若干の価格引下けとなつた。 すなわち原料高の生品安てある。

䅉物用については僅少てはあるか，物により需要か之 墰してきた。本期の後半は60余日にわたる長期炭労ス トのためコークス生產減し，またカス事業に捺いては 原料石炭不足を禣万ための自家用コークス（発生炻力 ス生產用) 垍となり。出荷の著しい減少ききたし，一 方コークススト，クは一掃され，一封的に壳手市湯の ことき観を呈した。

所要原料炭については，年間定通し，昨年同様匡队 優良原料炭の絕文湦不足から，無煙炭，强炶結炭拉上 ひ弱粘結炭の翰入を必要としたが，特にカス事業に拉 いては石炭ストの影響をてきるたけ䌅和するため人币 の弱粘結炭輸入の措置かとられた。

骂和27年度のコークス生牵祘よひ払出し，業種別荷 渡し状況は先机それ第 1 表挔よひ第 2 表のと特りであ る。

第1 表 昭和27年コークス生産および弘出実績

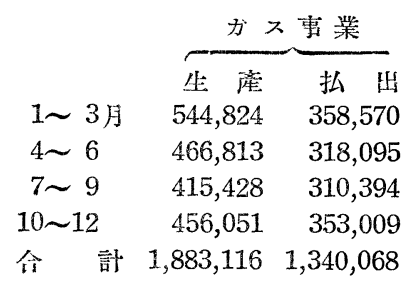

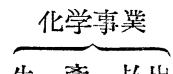

生 斈 払出 $28,6521,903$

$28,5312,093$

$27,557 \quad 2,154$

$25,5212,006$

$110,2618,156$

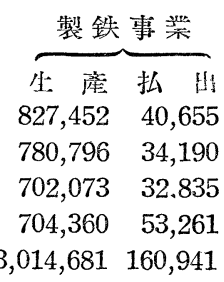

\section{第 2 表 昭和27年コークス業種别荷渡実績}

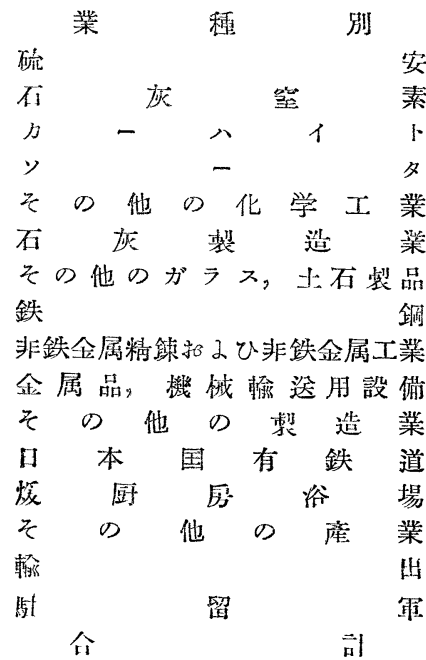

$\begin{array}{rr}1 \sim 3 \text { 月 } & 4 \sim 6 \text { 月 } \\ 122,675 & 94,514 \\ 65,339 & 67,142 \\ 17,842 & 15,202 \\ 13,472 & 11,194 \\ 11,214 & 11,618 \\ 5,441 & 3,528 \\ 7,366 & 4,616 \\ 196,179 & 175,610 \\ 42,463 & 45,188 \\ 58,800 & 50,778 \\ 26,052 & 24,331 \\ 3,304 & 8,128 \\ 19,199 & 8,363 \\ 11,438 & 10,994 \\ 518 & 30 \\ 66 & 781 \\ 601,368 & 532,017\end{array}$

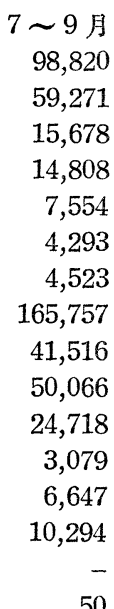

507,074

\begin{tabular}{|c|c|}
\hline $\begin{array}{l}\text { （単佁 } \\
\text { 合 }\end{array}$ & 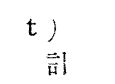 \\
\hline 生 竧 & \\
\hline$, 643,870$ & 631,908 \\
\hline$, 512,442$ & 579,107 \\
\hline$, 342,039$ & 541,140 \\
\hline 378,466 & 593,324 \\
\hline 876,817 & $2,345,479$ \\
\hline
\end{tabular}

烓 但し12月分织推定数量。 


\section{コークスに関する研究}

一昨年10月の本会第14回ニークス特別会において荚 場一致て探択された提案力实を結儿て昨年 5 月本会内 にコークス部会の設立を見，年 2 回の特別会と隔月こ

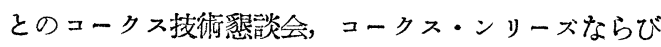
にコークス・サーキュラーの発行等によつて研究の発 表，意見の交換，相互の速絡ふむ寸をす活發となり， 加兄て製鉄 3 社，東京瓦斯等の民間大会社の機関誌 8 一通り出揃らに及んてコークスの研究は一段と活気を 呈してきた。昨年 4 月開催の䄰15回コークス特別会て は，八幡製鉄の前田氏のコークスの品質管理ならびに 東田第二ュークス偱の乾燥とその後の状況についての 報告をはしめとして，富士製鉄の久田氏はコークスの 强度に関する一考察, 太田氏は乾溜條件とコークスの 强度，また長崎氏らはコークス作業の 2,3 の條件, 長谷氏は配合と强度との関係, 都崎氏はコークス炬の 乾燥に高炬カスの利用, 堀氏は翰运中のコークスの粉 化，中島氏はオイルコークスの高炬便用実績について 迹一，日本鋼管の水野氏は䘫入炭の嵩密度，原田氏は 原料炭の風化䧼易制定法, 園田氏は $\mathrm{K} B \mathrm{~S}$ 装置によ る単味炭の膨脹について報告された。また東京瓦斯の 林氏は大森工場の起設に際して試みた諸裝置, 大阪瓦 斯の柳伬氏は試験等による各種炭のコークス化試験,

住友化学の橋本氏はュークス炬の溫度管理, 三菱化成 の硪部氏はコークス炬內のガス漏㖂試験, 日鉄鉱業の 唒井氏は北松地区の選炭の実休と將来の方向，三菱鉱 業の重富氏は沈澱微汾炭より治金用コークス製造につ いて報告され，さらに池貝鉄工の吉岡氏かアメリカの 㻌物用コークスとキュポラ熔解, 日本カーハイトの岩 井氏はカーバイト電炬用怙よび石灰炬用コークス，九 州耐火の松谷氏は乾溜所々耐火徚瓦の形状, 東人工学 部石川氏はサンプリングの考方方, 名大工学部の野田 氏らはコークス怙よびスートの黑鉆化，北大工学部の 武谷氏らはコークス化に関し從来行つた研究につい て，それそれ報告した（以上の要旨については本誌， 31, No 308, 574 80 参照)。

つついて昨年11月16回特別会ては，資技試の吉田氏 は本邦炭の軟化熔融性とその測定法, 富士製鉄の減本 氏は石炭の配合に対するプラストメータの利用，八幡 製鉄の井田氏は粘結成分量と纎維質の强さにもとつく 石炭粘結性の簡易刵定法, 東京瓦斯の田中(義)氏らか ガスの得熱を判定するすぐれた方法としてェレマ電気 炬による石炭乾溜試験について郝告され，また三菱化 成の重久氏はコークスのサンプリンクに関する考察， 富士製鉄の 岡谷氏はコークスの品質检定と自働探取
機，八幡製鉄の前田氏らは試験战を用いて行つたコー クス步留りに関する考察，日本鋼管の水野氏は試験师 によるタール回收，富士製鉄の今井氏はュークス炬現 場試験，三菱化成の北坂氏はォ，ト式コークス炬にお ける蓄熱式ノールフリューの酸蝕, 八幡製鉄の中原氏 はコークス炉の冷却について速へ，さらに八䊩製鉄の 井田氏はコークスの反応性，富士製鉄の上條代は高焻 用コークスの品質標隼，東京瓦斯の鈴木（操）氏はカ 一ヘイト用コークスについてそれそれ報告した。すた 前後 3 回のコークス技術留談会てはそれそれ粘結性,

実験室におけるコークス化試験，試験炬によるコーク ス化試験をテーマとして講演と活發な討論とか行われ

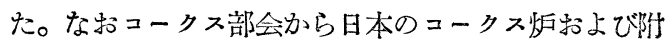
属設備の調查（第一回）とコークス試験炉調查の結果 とか発表された。

本会関係以外ては，む方原料炭の問題について，八 幡製鉄の前田氏は原料礼よび品質管理の統計からみた 原料事情について，日本鋼管の佐藤 (武) 氏少 Jharia 炭田の强粘結炭および Raniganj 岸田の配合用弱粘 結炭を中心とした印度炭の調查結果について，元䔵州 製鉄の三田氏らな高炬用コークス製造原料としてみた 満洲妨よび北支產石炭について速へ，缶燒試駼法につ いては富士製鉄の太田氏らふ粒度および裝大密度とコ ークス强度の関係, 装入方法の影響, 缶燒圾験の精度 扣よび作業炬コークスと缶燒コークスとの相関々係を 検討し，富士製鉄の福永氏はコークスの强度方破碎試 験後の総表面積に反比例寸るとの考元から石炭の粘結 力を定義し，このよらな定義にもとついてあらわした 粘結力か炭化度に比例与ることを多数の实験から明ら かにした。東京瓦斯の酩井氏らは休止中の炉を利用し て裝炭を行い粉碎度と本均嵩密度の関係を求め, むた 木製のモデル公を用いて各所の嵩密度の変化を測定 し，富士製鉄の久田氏らはコーライトコークスについ て種々の角度から検討を加えた。コークスの性状就よ び使用に関するものとしては，富士裴鉄の福水氏かコ 一クス充埃層の通気性について考察学試み，堀氏も二 つの異つたコークスについて考察を加え, 東京瓦斯の 北田氏らは無慓炭の代用としてオイルコーク, 非粘結 炭, コーライト、コークス粉をとれそれ配合しなコ一 クスを用いて熔解試験を行つた結果を報告し，オイル コークか最啇なこと，魅の人きざか重要な因子てある ことなとを明らかにした。炬に関するものとしては， 八幡製鉄の長谷湯氏らかコレクチンクメインの圧力を $6 \mathrm{~mm}$ に保つて行つた操業の実績について報出し, 東 京瓦斯の二階堂氏かっ，パース複式循環室嘿築造につ 
いて罳呵な說明を記速し，関氏らか鶴見工場の第 3 特 よび 4 嘿の改造工事と乾燥作業の詳細を報告した。 ークス挀の熱精算については東京瓦斯の酒井氏らの報 告がある。

海外ての研究状況是見ると，ます基礎的な方面ては H Mainz 氏がンークス化性の決定法とその意義につ いて, A. Lahiri 氏各沰炭のコロイド構造とコークス 生成機荋についてそれそれ論じているほか，熱分解そ の他に関する研究も少なくないがこれらは石炭の項に ゆする。乾溜に際しての膨脹圧の問題については J. D. Davis 氏らか膨脹と粒荛, 灯壁圧ならびに內部が ス圧なととの関係について検討し，英国コークス研究 協会ても可動壁式炊を用いて嵩比重, 加熱速度等の影 響を研究している。

製造に関するものとしては，わか国にもなじみの深 いF. H. Reed 氏ら分治金用コークスの製造を目的 としてイッノイ炭に対する数多くの東部地区の石炭の 配合試検結果を示し，ギーゼラープラストメータにも ふれてそれか配合のための石炭の適応性の判定に有用 でると迅べ，米国鉱山局はポカホンタス炭に対する 種々の石炭の配合試験堂引続き行つているほか，この 種のコークス化または配合試験の報告は少なくないよ らである。

裝入炭粉碎度がークス强度に及ぼす影響について は，A. Jenker 氏がドイツ炭について配合炭の微汾 碎か迴転强度に箸しい好結果をもたらすことを報じ， W Eland 氏は英国炭について弱粘結炭の場合に特に 微枌碎が有利てあるとの結果を示したが，一方ては A K. Mandel 氏らによつてドィッ炭に有效であると 郝告された微扮碎の効果をアメリカ炭について追試す ることも行われ，酸化の方がークス化性に対しより 大きな影響をもつことか啈告されている。

昐コークスの配合については F. Byrtus 氏方上部 ンレジア炭に $6 \%$ \%フリーズを配合して本工業規模の

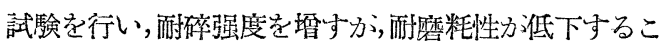
とを認めっこのコークスか高炬に適するかとらが評 洒するために强度試験前後の瑰の均一性，通風抵抗な とを測定した。弱粘結炭からコークスをつくろうとす る多少手の込んだ方法としては Y. Prax 氏がレー 又炭を用いて Carling, Marienau 怙よびThionville の3 工場て行われているそれぞれの満足导べき方法に ついてのべているが, これは Sabatier 氏らによりて 先にも紹介されたものである。むた E. Rubl 氏が弱 粘結炭の乾溜についてドイッ特許を得たほか，やゃ迁 遠てあるか沰炭の研究で有名な E. Berl 氏分無煙
炭，低炭化度炭またはりグナイトの存在下で高溫高压 て炭水化物定アルカリ处理したものを乾溜して冶金用 コークスを作る方法について米匡特許を得ている。

裝入炭水分については B Hofmeister 氏がール における平均水分 $10 \%$ か，米国の $5 \%$ と比してかなり 高い実情に照して，水分がークス作業能力に及ぼす 影響を検討し，水分を機栈的，熱的，むるいは Convertol 法のいすれによつて下げるにせよ，10\%から $6 \%$ に下ける費用は得られる利盆に比べれははるかに 小さいと逨べている。

操業條件と生成物との関係については，副童物に関 するものか多いのて，その一つ一つをあげないか， 3 の例をのべると P Damm 氏方漧溜㣠件とタール の收率およびその組成との関係について, W. I Jones 氏が加熱速度が生成物に及漂寺影響について，W。 Mante1 氏がガス牤よびガス夜の收率と組成につい $\tau, W$ Ruschmann 氏合成用原料ガス得る目的 で行つたパイロットプラント特よびュークス炊內ての 炭化水素の熱分解について，F. Trefny 氏がンーク ス版プラント操業のための实験室データについて論じ ている。

コークスの性質に関するものとしては，H L. Weisz 氏らか:100余のコークスについて自燃による溫 度上昇に基つく反䧹指数苍測定し，この指数力淇水 無灰基の揮発分量に此例寸ること起認め，反庆性力㵊 高乾溜溫度によつてきとしてきまるコークスの性質に 支配されるものであると速へ，S Banerjee 氏らは燃 烓を調節しつつ $1,300^{\circ} \mathrm{C}$ に保つてコークスの反応性を 測定与る方法を，また J. Telsbourg 氏らは水蒸気に 対する反応性を測定する裝置と操作法の詳細とを発表 Lた。J. D. Gilchrist 氏らは治金用コークスの気孔 の大きさの評洒法定紜說し，また A Romwalter 氏 はコークスの安定度か石墨結晶子の平均大きさの湎加 とともに潭すという関係を導き出し，かつ実証した。

F. J Hewitt，H. L. Riley 氏らは低品位粉炭の 配合による冾金用コークスの品質改善について検討を 加えるとともに，普通の試験法力特殊コークスの高炉 に括ける登動の指針とならないことを指摘しここのか わりとして强度試験としてのマイクロストレングス 法, 区広性試験としての湿式酸化法について述へた。 しかしコークスの性質まなは試験に関するものとして わふ帼の当事者の注目をひいたのは高燩用コークス評 価のための試験に関する R W. Campbell 氏の報告 である。同氏は高炏用ニークスの評価として（1）水 分, (2) 揮発分，(3) 灰分，(4) 硫黃，(5) 穊別 
試験 （6）タンブラ試験，（7）嵩密度の7 項目を挙 げている。しかしてタンブラ試験阷從来の標凖方法を 改め 400回転, 1/4in 指数を探るのがよいと述べてい る。

R J. Sarjant 氏は燃料と金属と題し，冶金用コ一 クスのもつべき性質 不炭の成分怙よび乾溜條件とコ ークスの性質との関係 熔銑炬內の反応に影響する因 子なとについて綜說している。

コークスの使用の面ではサイズを揃えて使らことの 重要さが治金方面で，わが国に拈けると同樣に，問題 にされているようである。Campbell 氏の報告のほか に，英国コークス研究協会 (B.C.R.A) で电高炉操 業に影響する最も重要な性質の一つであるという工業 界の意見をとりあげて研究を行いっコークスサイズと 高炬操業との関係に関する報告書が出されて和り， E. Piwowarsky 氏もサイズの重要性を强調してぷー トランドセメントを弱いコークスの小鬼に注入して良

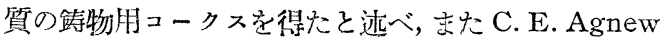

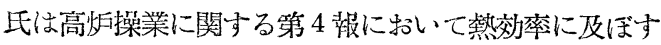
灰分の影響について報告している。このほか N. Y. Kirov 氏がコークブリーズの利用法としての蒸汽発 生，乾溜 䗲炭製浩その他についてのべている。

乾溜所の熱経済に関するものとしては, J. Newman 氏か加熱用発生炬ガス中の $\mathrm{CO}_{2}$ か $1 \%$ 增えると燃料 消費が $265 \%$ 謤し，畭溜炭 $\mathrm{t}$ 当りのコストか 4 ペンス 高となることを指摘し、プラントの抬業調節に要する 費用は利益に比して小さいとの意見をのべ，F.S Townend 氏は種々の幹溜法の熱経凪を比較し, 齐々 に邀した原料とその生成物とについて述べ，F.J. Dent 氏多不炭乾溜の熱效率について考察を下してい る。コークスの乾式消火む熱経斎の刘象としてしはし はとりあけられるか，W. Hersche 氏方第 5 回匤際が ス会議でその設備の改良についてのべ, E. A. Nizkewitsche 氏はンビェトての経験を報告し，その 最大の利点はコークス品質の改善でせると迅べてい る。な特特の主なものをあげると G. A. Davis 氏 (Allid Chem. \& Dye Corp.) か泝の 加熱のための 富ガスと賀ガスの混合について (英，米)，F．W． Dobson 氏 (ウ，ダル・ダ，カム会荆）がバ，クステ 1 の構造について (米), J. W. Drake 氏 (コッパー ス会注) カラプノシャーとコークガイドの連絡について

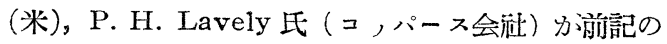
自働化について (米)，C. R. Plant 氏(サイモン・ カーブズ会社) がコークスの押出裝置について (英), Norsk 氏が電気乾溜について (ノルッェー) それぞ
れ特許を得ている。

\section{炭素に関する研究}

カーホンに関する研究を正しく分類することは非常 はもつかしいか，人体カーホンの基本的物性，カーホ ンの黑鉆化, カーボンによる吸着, カーボンの酸化お よびその他のものに人別して書くことにする。カーボ ンの基本的物性に関して， T. Doehaerd，P. Goldfinger および F. Waelbroeck 氏らはカーホンの年 華エネルギーを実験的に求めた。L. Brewer 氏は，品 鉛の蒸気圧を求め, F. Waelbroeck 氏は，黑鉛の蒸 着の機構に関して報告した。G. L. Dienes 氏らは， 黑鉛分子内の炭素原子の self-diffusion の機構につい て研究し，さらに C-14 放射性同位元素を用いての結 果を報告した。S. Mrozowski 氏は，黑鉆および縮令 多環化合物の牛導性就よび反磁性について報告し，ま た 黑鉛抢よび他のカーボンの熱云導性に関してて報告 した。G. E. Bacon 氏快，grindingによつて黑销 の結晶子の大きさか隇少し，目つ結晶としての完全性 が減少することを迹べた。L.QuartermanとW. Primak 両氏は，黑釦とカリウムの反応熱を精密に測 定して、密度の大きな Acheson 黑鉈に対して, 81士 $2 \mathrm{cal} / \mathrm{g}$ の値を得た。

F. E. Faris，L. Green および C. A. Smith 上 らは，黑䛇の彈性率と㴊性率が， $2,600^{\circ} \mathrm{C}$ までの盜度 変化において，溫度と共に潭加することを見出した。 J. B. Donnet そ J. Bossier 兩氏は, カーボンブラ ,クの粒子の形と人きさ電子顥微鏡によつて沃定し た。さらに炭素の電気的性質に関する豊出博夫氏の研 究 炭素牰よび黑鉛の熱伝導成々雪気伝導度との関聯 性を論じた田中忠良，岡田純兩氏の研究なと少恋る。

カーホンの黑鈶化に関する硼究のらち，主要な为の を列挙与ると，山口茂，野口利焳 八田三郎氏らの主 として黑铅化度の制定法に関する研究，石炭系および 石油系ピチュークスの黑鉛化性に関与る杉山幸男氏 の研究なとがある。また，ダイヤモンドの黑敍化を結 晶学的に取扳つた H. J. G. Wells 氏の研究为ある。 H. T. Pinnik 氏は，熱処理カーボン・ブラ，クをX 線迴折法で研究し，(101）趈折線の出現か; 結晶子の 大きさに関係があることを見出した。

カーホンの吸着に関する研究の中で，活性炭の檴造 については，H. L. McDermot および J. C. Arnell 両氏, M. M. Dubinin 呿よび E. D. Zaverina 両氏, V. I. Danilov 抢よび A. S. Serikov 両氏, V. I. Danilov 抢よび A. M. Zubko 両氏, V. A. Aleksandrov 氏らの研究力むり，また黑鉆によるメ 
タンの吸着に関する L Bonnetain 氏らの研究，カ ーボンブラノクによる GR-S 型高分子物の收着に関 する I. M Kolthoff およひ R. G. Gotmacher 雨 氏の湖究, R. B Anderson および P H Emmett 両氏のカーホンフラ,クによるいろいろの気体の吸着 の研究，さらに活性炭の㢈相吸着の機構岕よで昇承の 吸着に関する岡本岡比らの研究か女る。

カーボンの酸化反応に関しては,カーボンフラ，ク の高盗に打ける表面酸化物に関する R B Anderson および P H Emmett 雨氏の研究，A E Reif 氏 による $700 〜 1,000^{\circ} \mathrm{C}$ における一酸化炭素とコークス との反応に関する研究 E A Gulbrausen および K F Anorew 両氏による人造黑铅の気相酸化の機 㸴の研究, A E Reif 氏による炭酸カスと炭素の反 応の機構の研究，X Duval 氏による酸素吸着の研究 かむる。以上の他にも 仙石正氏らの混合炭素固体抵 抗肘素材としてのカーホンブラ,クに関卞る研究，赤 椞秀雄, 高橋浩両氏による石炭タール・ビ，千中の遊 離炭素に関与る研究，D H Volman および G J Doyle 兩氏の木炭の retentivity の研究なとかむる。

\section{家庭燃料の趨勢}

昭和27年度は前年度に比へて家庭燃料事情は著しく 艮好となり，ほとんと戦前の状熊に近ついた。最近に おいては，食糧こおけると同俕に供給量に対する不安 の念は去り，生活の向上に適店する良質燃料の撰択に 志寸倾向か强さつた。徒つて都市におけるガスの需要 はむすむ寸高むり，加工炭類も品質の问上を計りねは 需要の垤加定望以難きに至つた。昨炏，10〜12月にわ

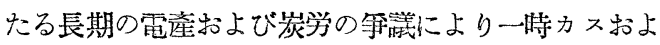
て電䔝使用の制限を受けたが，他種燃料の供給は豊富 てあつたのて，家庭生活上ないした不安を与充なかり た。

各種燃料の需給状態は次きのごとくてある。

（1）木炭 林野宁の調查によると昭和26年度の木 炭生產量は約 220 万 $\mathrm{t}$ てまつたか，27年度は約 201 万 $\mathrm{t}$ て 2 割弱の生掂減を示している。消費量の統計に执い て为，26年度の 194 万 $\mathrm{t}$ に比し，27年度は 177 万 $\mathrm{t}$ ， 約17万t の減量を示している。しかし一般に東京に扔 ける木炭の供給状態は良好て円滑に行われた。昭和 27 年度の全家庭燃料消費量は約 130 万 $\mathrm{t}$ と推定される。

都市家庭平均一世帯当り木炭消費量は，昭和26年度 の統計を見るにたいたい年間 9 俵内外てあるか, 東京， 人阪，名古屋なとの人都市においてはないたい７俵队 外て，木炭は大都市家庭においても冬期爰房燃料とし て相当量か使用されていることかわかる。
木炭の品種についてみるに, 白炭の生產か、年々減し， 黑炭の生道\%か次第に缅加している。たとえは全国に 招ける前者と後者との比か，昭和10年には 37.63 て あつた斥のか 昭和26年には 2575 となつているこ とは 比較的低廉な黑炭力次第に家庭に歓迎されるに 至つた鿉查て 白炭に比し黑炭の收炭萃の人なること

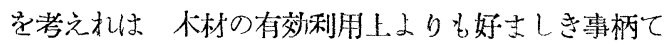
ある。

（2）薪 林野庁の統計による全国の欮の生逢数量 は昭和26年度の 33 丁宥樍石に比し 27 年度は 377 万 層㺓不を示している。同宁に打いては，统计外の数至

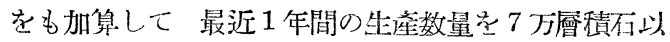
上と推定している。一方資源調查会の垁地调查による 全国家庭消費量は，さらに約この倍数を示している。

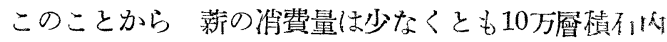
外には達するものと思われる。上就の 27 年度の林野广。 の統計数量は，27年 1 月より奏施された森林洗改止に

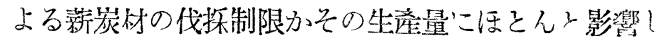
ていないことを示している。

都市家庭平诗一忙带当り藉消费量は，昭和 26 年没の 統計をみるにたいたい年間80貴內外てあるか，東京， 人阪においては25貫队外の少量てある。このことは次

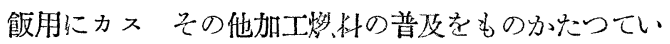
るか，名占屋市に朔いてのみは約100貴の消費を示し， 同市における薪価格の低廉 并の他特殊事情による准 費量の霓人を示している。

（3）加工㞸 昭和27年度の加工炭生红量は約 93 万t $\mathrm{t}$ その內訳は 煉炭 651 , 豆炭 185 , 炭団 30 , カラ炭 $637 \mathrm{t}$ てある。こ礼らの生産量は 昭和26年

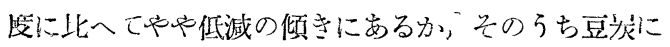
おいて特にこの倾向方むる。最近の加工炭の生産数量 は戦前の最高生產量に比へて約牛量に過きぬか，かか る需要減退の主因は品質の点と他種燃料に比一て割高 なためてあるのて，関係者の努力によつてこれらの䄈

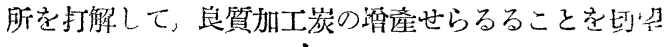
さる。

（4） カス 昭和27年度の家庭用カス消費量は 925 億 $\mathrm{m}^{3}$ て，前年层に比へて約 2 割の浯加てある。 27 年度の原料炭消費量は 2756 万 $\mathrm{t}$ て，ほかに重活 $125 千 \mathrm{kl}$ を消費し，前年に比へて約 $14 \%$ の增加に当 る。需要家戶数は 1826 万戶て, 前年度に比し 1 割の 堙加てある。全匡都市に扔けるガ ス普及率は27年 5 月 現在て 26 1\%を示し，東京兴の他の人都市に捣ける普 及率は $40 \%$ 內外をたはこれ以上てある。都市に当ける ガス消費量は年々著しく恓進している心，巨数の堆加 
とともに 1 月当りカス消費量为急激に墂加し，大都市 にあつては 1 カ月 $60 \mathrm{~m}^{3}$ 內外に達している。ガ製造 の原料として在来の石炭のほか一部石油原料の使用に より生座量の不足を補わんとされている。

（5）石泊 最近灯㣙類力安価に販売せらるるにと もない家庭の炊事並びに暖房用として石油コンロ，石 油ストープか传用せらるるに至つた。28年3月月末に特 けるこれら器具の普及状態は, 石油コンロ約 42 万台, ストーフ約 15 万台て, 過去半年閒に約 26 万kl の灯 油か消㙺せられたと推定されている。コンロ用灯油の 価格は 2001 につき的 3600 円 と称せられる。この価 格は他種然料に比し相当低廉てあるのて，今日の状態 を維持し得れば，今後家庭燃料として石油の使用量は

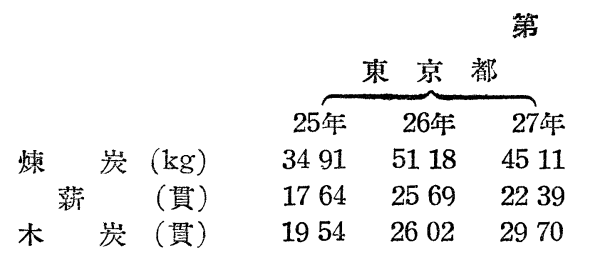

26年度に比へて 27 年度は相当大きな減少を示してい る。薪办東京都，名古屋に拉いて減少し，大阪市に拉 いて大美なく，木炭において各都甫とも謤加している ことは，森林法の実施によつて山林の保護と珸植によ る綠化運動の唱えられる折から一考を要与る。

豆炭の生産量は大阪南に预いて26年 $22,500 \mathrm{t}$ に站 し，27年 25,000 t てゃや垻加し，東京都においては 26年 $17,000 \mathrm{t}$ に対し，27年 $16,000 \mathrm{t}$ てやや減少して しる。

徚炭の品質は，27年には外炭（仏印無垔アアフリカ

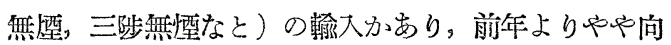
上し発熱量に括いて四寸徚炭は 5,300 から $5,500 \mathrm{cal}$ に，点数に就いて 150 230点から 180 260点の上晶 を示している。

現在豆炭には 2 種類あつてコンロのみに使用するむ のと，木炭代用として火钵、コタッに取つて立消兄し ない性状のものとあるか，寒地の都市および農村に対 して多量愛用せられるには後者の性状を持つことか必 要なのてある。しかしその生產量は, 原料と粘結肪に 制限学受けるなめ䍐らようにはならない。

27年の豆炭は，內地に掎けるコーライトの生產中止 により，これにかわる原料の使用をよきなくされ品質 にやや变化を来したか，たいたい発熱量 $5,500 \mathrm{cal}$ ，灰 分30\%程度のものか最高てあつた。

\section{铁道用燃料の遛勢}

著しく增加するものと考穴られる。

\section{棟岩工業の趨勢}

昭和27年度の加工炭 (䗲豆炭) の生產量は, 26年度 前期 3384 千 $\mathrm{t}$ に比して同期 3288 千 $\mathrm{t}$ の約 1 万 $\mathrm{t}$ 減 であり，後期には增遳を見込むれたか，年末の長期に

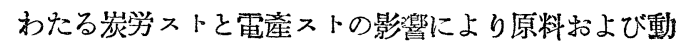
力の不足を来し，幸に外炭の輸入によりて原料の面に おいて禣われた感かあつた。また一方都市に特けるガ スの不足により棶豆炭の需要を来し，一时活況を呈し たが，結果に㧤いて大きな增加はみられなかつた。

東京都，名古屋市，人阪市に拗り一世带当りの煉 炭の購入量を 1 〜1月の合討てみると第 3 表のと呿り てある。

\begin{tabular}{rrrrrr}
3 & \multicolumn{3}{c}{$\begin{array}{c}\text { 表 } \\
\text { 名古屋市 }\end{array}$} & \multicolumn{3}{c}{ 大阪 市 } \\
25 年 & 26 年 & 27 年 & 25 年 & 26 年 & 27 年 \\
3358 & 4546 & 2887 & 3458 & 4766 & 4012 \\
6412 & 8995 & 8772 & 2151 & 1891 & 1898 \\
1906 & 2132 & 2275 & 1553 & 1939 & 2280
\end{tabular}

昭和26年度に国鉄力運転用に使用した石炭は 466 万 $\mathrm{t}$, 棶炭 94 万 $\mathrm{t}$ ，不均発熱量 $6,400 \mathrm{kcal} / \mathrm{kg}$, 粉炭の 混入割合は $40 \%$ てあつた。昭和 27 年度に入つた当初よ り石炭の需給事情かゃや好転し，27年 8 月前後には貯

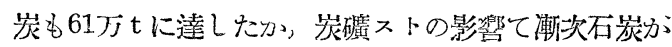
不足してきてついに11月21日には列車を減らすこと になつた。27年度の使用量は石炭 465 万 $\mathrm{t}$ ，䗲炭87万

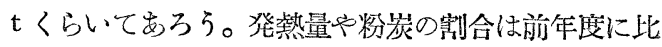
し多少劣るような見込久てある。

国鉄に货万徚炭は現在 $6,600 \mathrm{kcal} / \mathrm{kg}$ のものを睡入 しているふ，製造公礼は28工埸もり，品質に相当の善 異かみとめられる。釬道技術研究所以昭和26〜27年に 3次にわたり徚炭の比較試験を行つて，各泟製品の優 劣を比較した。徚炭の平均メリ，卜は石炭に比し $7 \%$ 良い程度てあつた。

石炭の入手難，また高価なことなとに刺践されて， 輸入炭も多少值つてきた。26年度には 3 万七のインド 炭党值つたし，27年度にはイント炭を 12 万 5 千 t, 台 浮炭 4 万 $\mathrm{t}$ 类入れる。イン卜炭は発㷫量 $6,800 \mathrm{kcal} / \mathrm{kg}$ 前後て，傎い上いかったたた大塊のものはその破碎に人 手要した。

同し理由て機関車に重油を併燃与る方法も試険的に 换用した。結果か良いのて今年度約 14,000k1 の重油 を使万实て，この重油併燃設供をもつを機関車も約 80両完成し，さらにふ方る倾向にある。この方法は助 
士 (火夫) の労力もへらすのて喜はれている。な和重 油を石炭に混せてたく方法（混燒）は良い成績を示さ なから。

またデーゼ几動車化も近い將来に行われる予定て， 幹線の電化にともない石炭は漸次減少する予定てむ り，今年为高崎線の電化て年間 6 万 $\mathrm{t}$ 箁約し，近く 行われる名占屋までの電化て約10万 $\mathrm{t}$ を減少すること

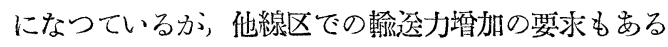
のて,この量か卡のままへるわけではない。さらに霞 化が淮めば火力発電所の設置も必要となり，卡の方面 に別途の石炭の需要面から学るであろう。

機関車から出る煙を減少する方法については各種の 方法力研究されているが，蒸汽エゼクタ式倠煙裝置か 有効なことかわかりたはたサイクロンを使ら方法,

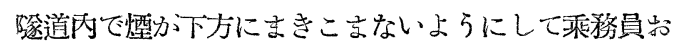
よび乘客の乘心地をよくをる方法, 煙を列車か巨遠く へとはせてしむう方法なとかいけれる試験されて, そ れそれ良い結果を与えている。

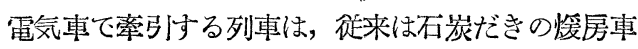
をつけるのか例であつたが，今回電気機関車の內部に 単管式の蒸汽発生裝置を取付けて，この目的を行わせ る方法を採用した。これには重油バーナを伐つてい る。いなた試験的な域にあるか相当將来性かむるもの てある。

\section{タールエ業の盗勢}

生産 昭和27年 (1月〜12月) のタール製品の生应 は，昨年より打続いた景気中だるみにもかかわらす， 1月〜3月まては順調な生育を続けてきたか，4月ご ろより潮落の過程をたとり，7月特よで 8 月に至り底 きつき，後平期逐次生库回復の兆力涀学出し再び上昇 を始めたか，10月中旬より始まつた炭学ストの影響に より各部門に款いて揮発分の少ない外国炭の传用が踶 加したため，タール製品の生產ば再び11月，12月に漸 落した。むすタール製品の根源てある裝入炭について みると，挛鉄，ガスの各部門裝炭量の漂加は他の減少 をカバーし，前年実禎 7,215,139 $\mathrm{t}$ (地方瓦斯を除く) に対し，7,660,243 $\mathrm{t}$ (地方瓦斯を除く) て約 $6 \%$ の旗 加で，前及年に対する比率は 144\%である。この他に 低溫乾餾留大炭 $184,690 \mathrm{t}$ があり, 前年実績は $313,628 \mathrm{t}$ で，41\%の減少であつた。これによるター

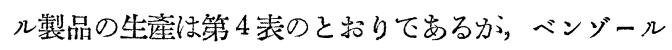
系製品は前年に比し $42 \%$ 減少, コールタール系製 品は $5.3 \%$ 垻加であつた。

表中で注目すべき点は, 前年より弓続き純ビリジン

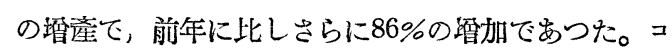

第 4 表 昭和 27 年タール製品生産量

(単位 $t$ )

\begin{tabular}{|c|c|c|}
\hline 品 & 数 & 量 \\
\hline 粗製ぶンゾール & $(1,715)$ & 73,915 \\
\hline 粗製 ベンゾール蒸溜量 & $(1,983)$ & 73,993 \\
\hline 純 ベン ゾール & & 23,588 \\
\hline 純 & & 4,289 \\
\hline$\neq \quad \Sigma \quad \square-\pi$ & & 1,298 \\
\hline $90 \%$ ベンジール & & 9,858 \\
\hline $60 \%$ ベン ジー - & & 2,641 \\
\hline $40 \%$ ベン ジール & & 4,136 \\
\hline ソルぶントナフタ & $(1,046)$ & 2,950 \\
\hline$=-\pi$ \& $-ル$ & $(16,608)$ & 364,427 \\
\hline コールタール蒸溜量 & $(15,989)$ & 335,849 \\
\hline ベンジール昅收油 & & 24,556 \\
\hline クレオン一下油 & $(9,204)$ & 83,636 \\
\hline ピ & $(4,833)$ & 200,713 \\
\hline 粗製ナフタリン & & 22,662 \\
\hline 粗製アントラセン & & 3,289 \\
\hline 分 溜 石 炭 酸 & & 848 \\
\hline クレゾール酸類 & $(409)$ & 2,655 \\
\hline その他のタール酸類 & $(57)$ & 745 \\
\hline 粗慜ナフタリン精製量 & & 21,690 \\
\hline 精製ナフタリン & & 11,495 \\
\hline 精製コールタール & & 11,881 \\
\hline 精製アントラセン（kg) & & 18,007 \\
\hline 精製カルバゾール（kg) & & 14,448 \\
\hline 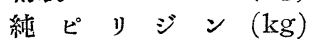 & & 88,861 \\
\hline
\end{tabular}

ールタール蒸溜量も前年に比し $76 \%$ 愐加し、コール タール生産量に対する蒸溜率も $92 \%$ と墰加した。昭和 28年は原料炭の輸入か泍年と同様て。銑鉄 420 万 t 实施されるとすれば，他の部門の裝入炭を加兄ると年 間裝入炭量は 1,000 万t超之るものと推定され，こ れにともならタール製品の蹧退も期待てきるわけであ る。

輸出入 昭和27年のタール製品の輸出についてみる そ, 純ベンゾール 6,700 t $(3,044 \mathrm{t})$, ビッチ11,500 t $(447 \mathrm{t})$, クレオンート油約 $14,800 \mathrm{t}(7,800 \mathrm{t})$, 精製 ナフタリン $1,062 \mathrm{t}(964 \mathrm{t})$ であつた輸入はクレッ゙ ール (12 t ) であつた。（カッュ內は大蔵省調查によ る6月まての実䋶)

需給 需給の状態は一般的にいらて好調てはなから た。すなわち上牛期に扔いては前年より打続く不況を 反映して需要頓に振わす，しかもこの事態に対してメ 一カーの生産ブレーキもきが，著大な在庫をかか学 るに至り，極端な表現をすれはター几製品業界末曾有 の不況時定招来し，逐には工場閉鎖の会社を現出せし めた。特に純ベンジール，ピ，チクレオッート油， 精製ナフタリンは輸出といら特別の手段をるつて需給 
バランスをとつた。比較的坚調であつたものは分溜石 炭酸、クレジール酸類, 純ビリジンであつた。しかし 下半期に至り, 需要も恢復し, 生產も上昇しはじめた が，炭労ストのため再び生產が落ちたため，上牛期と は逆の需給不均衡のまま年を越すことになつた。

規格 前年に制定された JIS，K2401ター几製品 (合成用)，JIS，K2402，タール製品（溶用），JIS， $\mathrm{K} 2403$ ，タール製品（ター几酸類），JIS，K2404，タ 一几製品 (防腐剂) に引続き，本年 5 月 JIS, K2405， タール製品（タール塩基類），JIS，K2406，タール製 品（加工タール），JIS，K2407，製品タール（タール ピ，チ）が制定された。

設備 本年 9 月より富士製鉄広烟製鉄所はター儿堛 基製造設備を完成，製造を開始しな。潼川事業所は 5 月工場閉敛清算事務に入つた。低溫乾櫭部門において は第一化学工業若松工場束 6 月操業中止, 本邦唯一の ルルキ式乾鱀炉もその火を落した。その他事業者の小 工場の休止したものか２工場むつた。

\section{タールに関する研究}

昭和27年度に括けるター儿関係の報告は內外ともに 昨年より引続き活潑をきわめ, ター儿蒸溜方法並びに 裝置の改良, タール成分全般にわたつて分㒕, 精製, 分 析の研究力衍われ，先の報告多数にのぼつている。 特にインニュチン酸ヒドラヂットが結核薬として発 表されてより,タール塩基に対寸る関心为高まつた。

ま蒸溜設确については山本, 岡氏の管式タール蒸 溜裝置の試験報告，山本，安田，田原氏ら，大竹，柳 田, 渉谷, 小鳥, 和泉氏らは連続蒸溜装置の溫度分布, 熱計算を研究し，その他加熱管の腐蝕、コーキングの 防止について好結果を得ている。关の他精溜塔の改良 方法, T. Wiltonの熱ビ,チの還流による加熱方式な との英国特許子岕る。蒸溜に際して村質腐蝕は從来か ら問題とされているが，安東 山本氏は鉄に対する腐 蝕を研究し, 処理盜度か著しく影響することを認めて いる。王置，平松両氏抢よで安永，高木，自鍋氏らは ベンゾール類の腐蝕についてのベ,ンーダ溶液を通ず ることにより防ぎ得ることを迹べている。

W. Fuches 抽よび K. Hamacher 両氏は乾溜盜度 その池の條件による低溫タールの組成の变化，乾溜に よる各成分の生成機欟なとについて迹へ，木村，後藤 両氏は前年に引続きガス軽油成分を比較し，炉式によ るべンゼントトルェンなとの收率を比較した。日比野， 武井, 鈴树氏をた Wm. Yates 氏はキシレンの翼性体 の分離を行い，スルフォン化によりメタ，パラを分離 L，M. Souder 氏は低溫にてノルマルヘプタン，液
体アンモニヤに溶解し，メタ，パラを分離している。 木村，鈴村，安井氏は八幡製鉄のソルベントナフッの キシレン中にパラがメタの倍量あり，オルトは痕跡で あり，またソルベントナフ少中のノルマルパラフィン はノルマルデカンとノルマルウンデカンであることを 認めた。ベンゾールの精製については報告多く，その 万ち J. Anderson 氏はシクロへキサンなとの非芳香 族炭化水素とメタノールなとの極性ある溶剤と共沸せ しめて非芳香族炭化水素を含むべンゼンを精製する， 水素涯加によつての脫硫する方法なとを提出してい る。その他脫硫に関卞る報告は多い。

酸性油に関しては雨赏, 常富, 中沢氏らは本邦条㼛 の 1 号クレゾールの組成を研究しォルトとメタ間に相 互墰減関係がり，パラはそれに比しかなり変動か少 ないことを示した。また30〜40段の精溜管を用いて酸 性油特にクレゾール異性体の分離を試み, メタ,パラク レゾール以外の成分は完全に分離し得ている。吉田,

日比野, 村上, 鳥山氏らは工業用キシレノールを分溜 しンーダ塩の溶解度の美, スルフォン酸の脫スルフち ン酸の溫度善を利用して 1，3，5-キシレノールを分 離確認し，穴の他 1，2，5-，1，3，4-キシレノール当 举離している。C. Golumbic, M Orchin 雨氏はべ ンゾール拉よび燐酸塩バ,ハーにて向流抽出しこフェ ノール類を、また J. Kleinert 氏は工業用ッグニンで 処理し濾過したフェノールを分離する方法を迹べてい る。S Savitt, D. Othmer 雨氏はメタおよがパラク レゾールをクレゾールベンジジンの附加化合物により 分離している。

塩基は昨年に続いて硫安母液よりの回收か盛んに行 われ，鳥津，細井両氏は硫安団液上り回收した粗ビッ ヂンの処理方法を, 久村, 岡崎, 加藤氏らは回收につ いて中和分離法と中和蒸溜法を検討し，綮基の回收率 は50\%でることを認めている。また安滕氏は 2，6ルチヂンの分離方法として中紴アルコール溶液に塩化

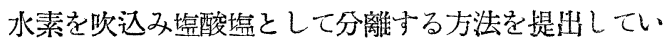
る。塩基の分析として特に吸收スペクトルによる分析 の郝告方多く，木村，勝本両氏は紫外部吸收スペクト ルにより $2 \%$ の誤差てビコリンの定量を，松本，深 沢両氏は近紫外部スペクトルを浿定し，分析に応用し 得ることを認めている。C Ballard， P. Scott 雨氏 は 1-クロロ-2，4-チニトロベンゾールによる 4-ビ コ リンの分析の改莨法について连へている。

アントラセンは他にフェナントレン, カルバゾール を含むがこれの精製方法として，芦田，清水両氏は精 彆溶偊としてのビリチンの代用としてフルフラール扔 
よびフラン系溶刜を侦用することを研究し，30\%アン トラセンを含主粗製品に対して 2 〜 倍量, $90 \%$ のア ントラセンを含むものには 3 〜 倍を用いてカルバゾ ールを除去し得ている。V. Borodkin 氏はカルバジ ールをスルフォン化して, H. de Bruijn 氏はカルパ ゾールを硫酸塩として有機溶剤て処理して分離してい る。

その他タール或分の利用方法としては，船久保氏ら の鉄鋼の表面妈理剤として用いること，雨䆓氏らはカ ルバゾールのニトロ化によるテトラニトロカルバゾー 几を合成し殺虫剤として利朋卞ること, 井上氏のクマ ロン樹脂を印刷用インテとして利用することなとの研 究活る。

\section{都市ガスエ業の趨勢}

27 年（1月〜12月）の都市ガス工举は前年に引続き 活况を呈し，家庭用，商工業用のカスの需要は共に著 しく堆加し，前年に比し21\%の上昇率を示した。もし 年末の炭労のストライキかなく，一部ガスの供給制限

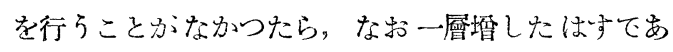
る。

第 5 表は昨年 1 力年の都市か ス工業の全貌でする。

\section{第 5 表 昭和27年のガスエ業統計}

(12月の数字泣一部推定)

力又事業者数 78

(队 1 社休止， 2 泼準碏中)

(12月末現在)

分ス製造工場数 162

（內 4 工場休止，2工場集硆中)

(12月末現在)

石炭入荷量 $2,786,899 \mathrm{\tau}$

石炭消費量 $2,790,700 \mathrm{t}$

(队 $\left\{\begin{array}{lr}\text { 輸 大炭 } & 608,300 \mathrm{t} \\ \text { 燃燒用 } & 19,012 \mathrm{t}\end{array}\right)$

ガス製造量

(内燃燒用炭 $35,515 \mathrm{t}$ )

$1,645,406,709 \mathrm{~m}^{3}$

（天然ガス打よひ購入ガスを含 x-y-数

ガス供給星 $1,518,550,729 \mathrm{~m}^{3} \quad(1,806,553)$

家庭目 $923,582,116 \mathrm{~m}^{3} \quad(1,700,770)$

工菜 用 $250,087,585 \mathrm{~m}^{3} \quad(14,433)$

樎 䅈 用 $215,891,771 \mathrm{~m}^{3}$ ( 70,601)

九の他用 $128,989,257 \mathrm{~m}^{3}$ ( 20,749)

自家用かス $48,729,525 \mathrm{~m}^{3}$ (㢳㘩用を含

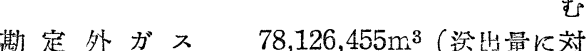

コークス生遳量 $1,885,233 \mathrm{t}$

コークス販壳量 $1,340,946 \mathrm{t}$

タ一ル生產量 $136,534 \mathrm{t}$

ベンッール生產量 $\quad 5,253 \mathrm{t}$

䟽安尘宸量 $19,122 \mathrm{t}$
昨年中ガス工業て特等すへきことに次ぎのようなる のがある。

（1）昭和25年末わか国て䘞めててきた公益事業委 員会はわすか 1 年余の寿命て廃止され，昭和 27 年 8 月 1 日から電気およびカ ス事業の監督は再び通商䤤業省 に還り、欶たにてきた公益事業局が湩に当り，ガ ス事業に対してはカ ス課力㨁接の監督庁となつた。

公益事業令は10月25日すへてのポツダム條約による 政命方决効した時に失效し，年末12月27日に電気和よ びガスに関卞る臨時措置に関する法律か出て，徒来の 事業令を踏襲することとなつたか，近く新らしいガス

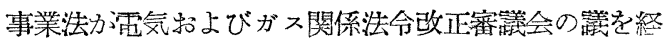
て国会に提出されるはすである。

（2）ガス料金は昭和26年11月当時の公盛事業委員 会の認可党得て改訂されたか;，その後引続き高腾した 炭価，渐設にともな5償却の增額なとに対応して6月

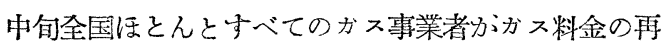
值上げを虫請し，昨年11月 1 日から最低 $100 \%$ ，最高 $28.5 \%$ 值上けを実施することか認可された。すなわ ち平均料金 $\left(1 \mathrm{~m}^{3}\right.$ 当り) 最低 12 円00銭, 最高 22 冈13銭 となつた。たとえは京浜地区に拈ける值上率は14 5\% て平均が料金は15门52銭でる。

䚾：上記の料金は早收料金てガス税を含まないものて まる。 -

（3）昨年中もカ 引続き必要最小限度行われ，新たにスタートしたもの， または建設中のもののらち市な設備に次ぎのようなる のがあつた。

大阪分ス 酉島工場 Otto 式コークス炉 45 公 1 聯 (650t石炭/日) および 附属設備)

Koppers式プロチューサー 9 基

東京ガス 千仕工場 $150 \mathrm{t}$ 重油/日のオイルカス プラント3基

北海道力 札愰工場 小型荎式版 9 室

中部ガス 浜松工場 貴通式水平レトルト3門

北陸ガス 新鼬地区 径 $8 \mathrm{in}$, 深度 $685 \mathrm{~m}$, 内面七 メント塗裝のガス并 1 本, 自噴約 $3,000 \mathrm{~m}^{3} /$ 日 別に 8 in, 深度 $215 \mathrm{~m}$ のガ 长 1 本，約 $1,200 \mathrm{~m}^{3} /$ 日

東邦ガス 金川工昜 Otto 式コークス炉20室 1 聯 (260 t 石炭/日) 建設中 阪偣連絡高圧導管 延長 $329 \mathrm{~km}$ 口径 500 
$300 \mathrm{~mm}$, 熔接鋼管（最人輸

湀力 : $572,000 \mathrm{~m}^{3} /$ 日)

（4） 1 昨年は異常渴水による発電用石炭の激湓と 11月の石炭ストライキによりカス工業は一時その乾溜 用炭の入手に苦しんだふう,昨年末10月13日から始まり， 夹に64日も続いたわ方国石炭更上いまたからて見ない 人梘模な炭労ストライキのガス工業に対する影響はき わめて深刻て，ガス事業者はあらゆる手を施して，䠉 炭の食い延しを行つたか，11月末に至り，ついに京浜， 京阪神，名古屋地区定はじめ各地区の一部のガスの供 給は時限供給のやさなきに至つた。しかし12月17日ス トライキ停止とともに內地炭の供給も伹先輸迭により 目当てからき，一方米国炭の輸入も胋調に行われたた め，年末にはほとにるすへて24時間供給の常態にもと ることがてきた。

だいたいガス工場の詝炭量は天㷋による石炭輸运の 一性杜絕を考慮し, 最少 2 週間分, 普通 1 力月分の貯 炭を持つの常法であるが，だれしも予期しない2 月以上にもわたる長期石炭ストライキにもかかわら げ，少数のガ ス事業都がある程度のガスの供給制限を 行つたのみで,この難関を町り拢けたことは賞すべき でる。

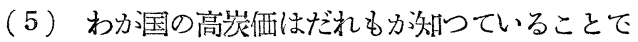
岁るか，最近ガス工篻界に特いてもようやく乾溜用炭 以外の原料を用いて都市ガスを製造することに䍐いを 致す傾向か泏て来た。この時に当り前記の長期の石炭 ストライキに会い，好むと好まざるにかかわらす，石 炭以外のものを原料として都市がスを作る工夫をしな けれはならない状態に特いこまれた。

東京カ ス千住工吻では，一昨年から從来の水性ガス 隼置胥利用してォイルガス製造の試験を続行していた が，昨年末には正式のオイルガスプラント（1基重油 妈理量 $150 \mathrm{t} /$ 日）2基力渾転を開始し, 石炭飢饉の急 場起救らため非常に役立つた。

また從来の水平レトルト内でオイルガスを作る試み も各所で行われ，最も原始的なものは石炭チャーチに あらかじめ重油を混和して装炭するものから，空坩中 に重油をそのまま压力下で注入して，クラックするも のふ続出し，相当の成績を得た。

大阪ガスではコークス炬を利用し，軽油のガス化に 成功した由である。

その他，圧縮天然がスをボンべて輸邆して，石炭が スに混和与るものや，液体プロパン，ブタンガス（L P) をカス化して混和与ることなどが数工暢で試みら れた。
以上多くの斗のは急場においこまれて，早急に行わ れたものて，人した基礎的研究を経すして直ちに奏行 に移されたにもかかわらす，事故もなく，先机それ相 当の成績を挙け得たことは慶すへきてある。

今後この経験を生かして，冬期かスのビークロード 対策として石炭以外の原料（主として石油系炭化水 素）を用いて都市がス圶製造することか常法化する可 能性か强くなつたことは注目に佗する。

この場合注意しなけれはならないことは，水素の少 ない高鲑量炭化水素が スふ混大した都市がスの燃燒性 の研究，むなわちか ス器具の改呫の問题でる。此較 的混大量力少ない歾合にほその影響はほとしとないと しても美支えないか，約牛量以上かかる高熱量力 スを 混和しよらとされは，ガ此重の堦加も考慮して，都 市ガスの熱量を上良せしめるとともに，ガス器具バー ナーの改变芷ある程度考慮しなけれは，完全な利用は 困難であることをむらかじめ知つて特かなけれはなら $\$ 20$

\section{ガス化エ業の䞶勢}

合成化学用の原料力 ス, 工晹然料用の発生炉力 ス括 よび都市かス稀釈用のカスなとの製造について，表面 に現われた人きな変化はみられないふ，発生师用炭の 需給状況は依然として好䢂しないために，これか打開 をはかるべく活潑な底流かるられた。すなわち，発生 炘用炭の生栍は依然として月 250 万t 前後て, 輸大の 期待し得るものもなく，特に年末に至つての炭学スト は一特重人な暗影を投げた。合成用特にアっモニア原 料ガスの問題は，製品硫安価格力匡際競争場裡におい て明白に割高であることを立証されたために，これが 主要な合理化方法として第一に探り上げられ，当局の 要望と相まつて新しいカス化注の探究か盛儿に行われ た。その結果主として微粉炭かス化法ふその研究の対 象となつた。同法は Koppers 社の手によつて27年7 月フィンランドの Typpi Oy てアンモニア用として $80,000 \mathrm{~m}^{3} /$ 日のプラントが軍転を開始し，一方米国に 特いても American Koppers による同法かＵ.S. Bur. Mines て研究起淮められている。後者の発表に よれは，低炭化度の反応性高きむのに有利て，炭化度 の進行および微粉りイズの颈加は共にガス化率および 効率の低下を示している。このほか Flesch 博士によ るいわゆる Demag-Flesch 法も， B. S. A. F. にお いて順調に研究を進行し，年末より歴青炭による試験 を開始したといわれる。これに関聯し既存のウィンク ラー炊の改良かわふ国の数社によつて子考光られてい るようである。しかしながら，問題はこれらのガス製 
造の技少的進步によつて得られるコスト低下は，希望 する合理化の一部に過きないとみられている点て，カ ス用炭あるいはコークスの高值をいかにすべきかに当 面の問題は向つているといら実情であつた。工場然料 用のガス発生师についても同様なことか洘えられ，そ れそれ対策を探究しているか，目立つた動きには至つ ていない。外国に特いては, Lurgi による加圧カ ス化 法の発展か矓ち，建設を開始したものは，南阿の Johannesburgにフィノンャ一法による合成石油年㡾

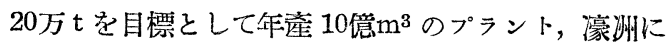
Melborn の都市が用として第一期に年㡾 1 億 $\mathrm{m}^{3}$ の プラントか建設に着手し，前者は牛無㖶炭，後者は褐 炭を原料とするといら。一方西独に物いては Ruhr 地 方に Ruhr Gas A. G. カ洞洼によるプラントの建設 を決定し，いわゆる Fern Gas の消費唔大に備えよ らとしている。それ以外かつて報告されたいくつかの 新しいガス化法はその後目立つた進出を示していない が，米国に捖いて主主として合成ガス用として微枌炭 ガス化に期待をかけているようて，Bur of Minesの Elliot 氏らか: Vortex 型の微汾炭が化装置による 実験を報告している。

地下ガス化に関しては米国の Bur. of Mines が從 来の研究の結果を発表したが，それによれは最近の 22 カ月間にガス化した石炭は約 $10,000 \mathrm{t}$ に達し, 延べ面 樍は 15 ha に及ぶっ最近の 4 カ月の実績としては，石 炭の熱量の $65 \%$ か有效に利用され，今日まての最高で あるといつている。結論としては從来いわれていると ころと大差なく，孤立した埋蔵あるいは賀弱な薄層で 普通の稼行か困難な場合に特に有利て，合成石油用と して，あるいは合成化学用として將来性かあるものと みている。

\section{カス化に関する研究}

1952年に括けるわか国のカ化関する研究として は，矢木栄氏らの流動法による㸮コークスガス化の基 礎的研究のほか，あまり重要な発表はなからた。しか し海外てはつきつきと新しい研究か発表され，それら の中て特に粉むたは微汾然料を原料とするところの高 速ないし流動状態に括けるガス化法の発展か著しい。 これらの方法は，從来のガス化の上らに合成ガ，水 性ガスおよ゙発生炬ガスの製造法であるのみならす, 都市カスの製造法てもあることは，將来のカス化方式 の発展を考光る上に重要な事柄てある。わ力国もこれ らの新しいガス化法に深い関心を払わざるを得ない立 場にあつて, 硫安工業界ては, ガス法硫安のコスト引 下けの必要から, 各社とも有力な技術担当者を海外視
察に揆つて新しいガス化技術の導大につとめており， やかて從来の高価な原料炭からつくつた中塊コークス を間歇式水性がス発生炘でが化する方式と置き換元 ら机る䞶勢にある。ウインクラー式の粉末流動がス化 に山多くの改良型か提案されている。都市ガス工業て は, 年々カスの需要か增大して行くほか, 夏季と冬季 の季節的变動力渄常に大きくなつてきて，これに対応 するため設備費か洝くて始動停止か溶易なガス化の裝 置を要求している。またがスの需要の今後の增加に呅 し, コークスの需要はこれにともなわないことか予想 されるので, 將来のガス製造法としてガス用炭以外の 微粘結炭や非粘結炭を原料とする新しい完全ガス化に よる方式か注目されている。また，海外の文献による そガスターヒンの発展につれて大容量て安価なガスを 得るガス発生炬力㴗求されているが，わ力国てもやが て同じような問題か性することと思われる。

海外の多数の文献の中から主要なものを若干紹介す ると，1952年 2 月ニューョークて開かれた米匡鉱山治 金技術者協会大会の石炭部門の講演にはガス化に関す るものか 8つあつた。

(1) BASF一Flesch-Demag法 これはWinkler 法の改良型ともい5べきもので，2つのガス化室か 1 組となつて㧍り，酸素を使用することなく水性カスか～ 製造され，使用粉炭の粒度の巾か人きくから炭塺損失 の少ないのか特徴て, 東京瓦斯犬伏昌治氏は 9 月13日 燃料協会例会講演会に招いて本法を紹介した。

(2) Moving Burden 法 Imperial Chemical Industries Co か伴工業試験を行つている 方法て, 燃燒室とスチーミンク室とは別になつている。燃燒室 では粉コークスの 1〜 2\%力燃然し, その発生熱は過 剩のコークスか吸收して高速て粉コークスバンカーに 吹き上げられ，ついでスチーミング窒に流下し，新た に装入される粉炭とともにスチームて流動化されつり ガス化される。コークスの大部分はさらに循環して燃 蹺空に行く。酸素を必要としないて連続的に水性ガス の製造ができるのカ特徽である。

(3) Fuel Research Station 法 外熱式の石炭 流動ガス化法である。

(4) Texas Co. 法

（5） U.S. Bureau of Mines 法この2つはよ く似た方法で，粉炭を20〜30気圧で酸素とスチームて ガス化し，灰はスラグとして除去する。

（6）加圧ガス化法 中魄炭を空気とスチームによ つて6気圧以下でカス化する方法で, General Electric Co. と Battele Memorial Inst か溌表している。 
（7） L. L. Newman氏はガス製浩法の発展の今 後の向について述べた。

(8) M. H. Fies は Alabama 州 Gorgas の地 下ガス化について報告した。GWF̣ の1952年10月1日 号には，K. Traenckner 氏がュークス用にならない 炭からのガス製造といら題で Ruhrgas A. G. で行わ れたガス化試験について速べている。(1) Wirbelkammer 法は通常の流動ガス化法であるか；（2）Schmidtrohr 法は少し変つた方法で, 內径 $50 \mathrm{~cm}$ 長さ 3.5 〜 $4.0 \mathrm{~m}$ の管の一端から燃料と空気を導入して爆発さ せると生成がス過剩の然料は圧力波となつて他の一 端二押して行き，出口拿加開いて生成か スは排出され るが，圧力波はさらに区射してもとるため弇は閉まる。

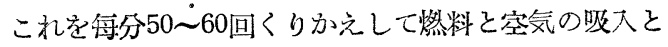
生成ガスの挑出を行う。(3) Lurgi の高压ガス化法, (4) LR法は Lurgi か考案して Ruhrgas か体工業試 験を行つており，これはガスやスチームを加熱する Pebble Heater に似ており，酸素を使用することな く固体の熱渾搬体を利用して連続的に石炭の乾溜とガ ス化を行5。ドィッ褐炭学使用して $2,980 \mathrm{kcal} / \mathrm{m}^{3}$ の ガスを $3,200 \mathrm{Nm}^{3} / \mathrm{m}^{2} \cdot \mathrm{hr}$ 得ている。な括，この LR 法でも先にのへた Moving Burden 法でも類似の研 究や特許かほかにいくつか存在することを附言する。

BWKの 1 月号てはF. Danulat氏が Lurgi 高圧が ス化法の発展の現状と將来の見透しについて迹べ，中 には高圧てあると同時にスラノグタッビング式て合成
ガスまねは水性カスをつくる方法も計画されている。 同じ 1 月号にK.H Osthaus 氏は Koppers-Totzek 法を引用して微粉炭カス化の方式や憡転法について述 ベ, S Traŭtsel 氏はガス化反応の本衡㤐論している。 Ind Eng. Chem.の5月および 6 月号はカ ス化特咕 号て，合計11篇の眽告㢷り，主として炭素かいろい ろな條件下に酸素やスチームや炭酸ガスと反応する際 の穖㥏や熱力学について論じられ，その中には加圧ガ ス化や微粉炭のVortex 式ガス化に関するものも含ま れている。その他 J Inst Fuel の 182頁には L G. Townsend 氏分発生炊操業に及ほ方灰分の影響につ いて远べたものや，Chem. Ing. Tech の349頁には 英国やロシャの研究者のデータを引用してカス化反掂 の機楛と動万学を綜說したものがある。

石炭地下カス化については新しい試験結果の発表は ないかいくつかの特許忍 Chemical Abstractsに のつている。

\section{天然ガス利用の趨勢}

戦後の一般燃料不足時に自動車燃料不足の波に乘つ て急激に発展したわか国の天然ガスは，その後ガッッ ン，重油なとの石油系燃料の供給力閵沢になつてきた のて，用途の分野に多少約余曲折がありたが その本 質的価值は漸次师人の認生るところとなり，ローカル

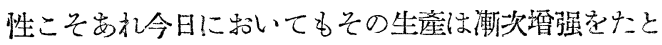
つている。その状洗は第 6 表のと物りてまる。

\begin{tabular}{|c|c|c|c|c|c|c|c|c|c|}
\hline \multirow[b]{2}{*}{ 種 } & & & \multicolumn{2}{|c|}{ 第 6 表 } & \multicolumn{2}{|c|}{ 本邦天然ガス生産年次表 } & \multicolumn{3}{|c|}{ (単位 $1,000 \mathrm{~m}^{3}$ ) } \\
\hline & 別 & 次 & 昭和21年 & 22 & 23 年 & & 25 年 & 26 年 & 27 年 \\
\hline ウ & $x$ & r & 28,793 & 26,488 & 23,984 & 22,733 & 23,813 & 24,158 & 23,117 \\
\hline & ラ & 1 & 7,004 & 8,644 & 27,130 & 35,110 & 45,016 & 58,603 & 71,512 \\
\hline & 詁 & & 35,797 & 35,132 & 51,114 & 57,843 & 68,829 & 82,761 & 94,629 \\
\hline
\end{tabular}

特に昭和26年なかはより，東京都を中心とした関東 カス田の発見によりその開発は一愿世人の注目すると ころとなつた。

昨年まては天然ガスの利䏳分野は燃料のみてあつた か，かねてからの化学工業原料としての研究か結象事 業化し，27年11月より日本瓦斯化学工業株式会社は新 潟にメタノール工場の操業を開始するに至りここに わわ帼の天然分 スの用途心劃期的の一線を画くに至つ た。

燃料としての天然がスは圧縮ガスと生ガスに二大別 しちること從来のと括りて，年次利用比率（生產に対 寸る百分率) を示せは第 7 表のとおりて，圧縮がスの 利用量は26年上期旮頂点として漸減している。

\begin{tabular}{|c|c|c|c|c|c|c|}
\hline & 第 & 7 & 表 & & & \\
\hline & $\begin{array}{l}\text { 昭和 } \\
24 \text { 年 }\end{array}$ & 25年 & & & $\begin{array}{l}27 \text { 年 } \\
\text { 下期 }\end{array}$ & $\begin{array}{l}\text { 27年 } \\
\text { 11月 }\end{array}$ \\
\hline 然 $\left\{\begin{array}{l}\text { 圧縮カ } \\
\text { 生 ガ }\end{array}\right.$ & $\begin{array}{l}225 \\
77.5\end{array}$ & $\begin{array}{l}25 \\
75\end{array}$ & $\begin{array}{l}27 \\
73\end{array}$ & $\begin{array}{l}24 \\
76\end{array}$ & $\begin{array}{l}21 \\
79\end{array}$ & $\begin{array}{l}18 \\
76\end{array}$ \\
\hline 化学工業原料 & - & - & - & - & - & 6 \\
\hline
\end{tabular}

圧縮ガスは自動車とガスカー然料として使用するを 目的としていたか，26年下期以来自動車然料はカッッ ンの供給潤沢となつたのと，カスカーか重油化したた め, 天然ガスを有利とする生笙地附近以外で，自動 車燃料としての発展性はなくなつた。征つて圧縮ガス の余剩力は他燃料, たとえは木炭, 新, 煤炭なとの家 庭然料面に向けられ，軽便にして割安なる燃燒器具の 
案出による業者の販路拡張サー七スは效を奏し，千葉 祡, 東京都, 湘南地方, 静岡県燒冿地方, 福島県勿来 町なとは相当の成䋶を挙ぐるに至つた。その趨勢は第 7 表に示すと抢りてある。昨年末の炭磺，電力ストの

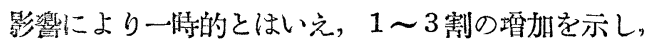
一愿々の発展性に拍車をかけ，製造元たる千葉罢大多 喜天然瓦斯株式会社，日本天然瓦斯與業株式会社なと は東京都怙よびその近県より注交殺到し，ホンへなと の能力一パイの供給に忙殺された状況てあつた。

現在てはストは停止したか, カス燃档の価值と取扱 いの軽便は他燃炓の追從を针さないのて，天然がスの 価値宣伝上相当効果かあつた。特に飲食業者にこの傾 向著しい。

一方薪舅地区に执いては，カ又稅の廃止を機として 低価格策起强調し, ガッリンと対抗している状況てあ る。生カスは従来のと打りパイプ供給にて工場へ、ま なはカス会酒をへて各家庭に配給されている。

最近瓶津天然瓦斯鈗業株式会社ては，圧縮カスの販 路不振の余力を烍津市の都市ガスに転換し，成果をあ けこいる。東京方面の圧縮メタンカスの用途 $(\%)$ 䞶 沙は第8表のと抢りてある。

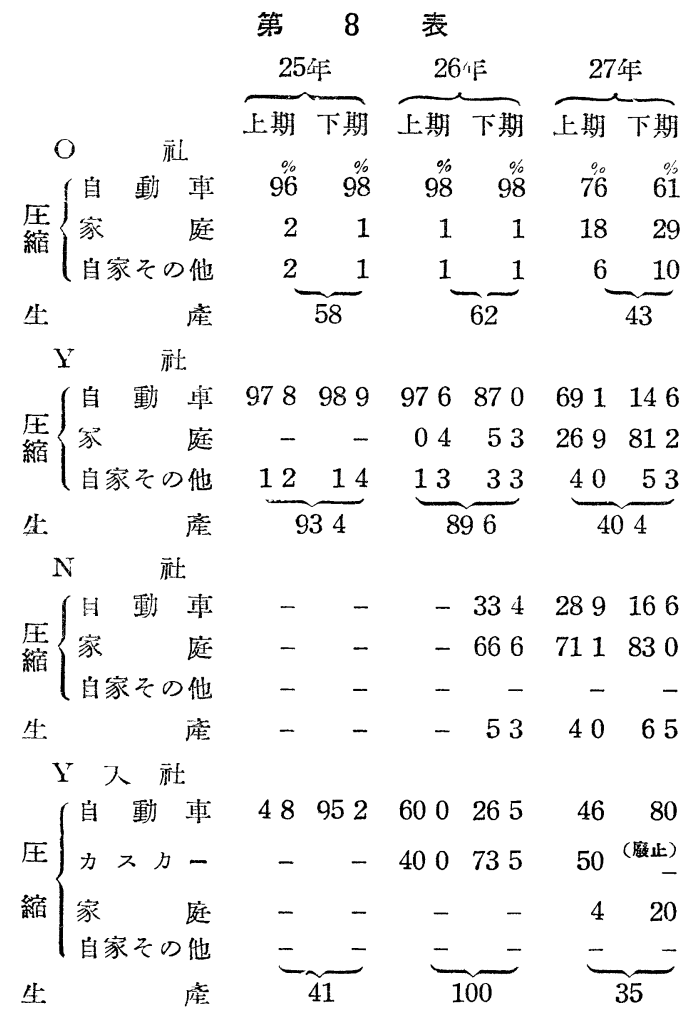

メタンカスの一般利用概況は第 9 表のと㧍りてあ
る。

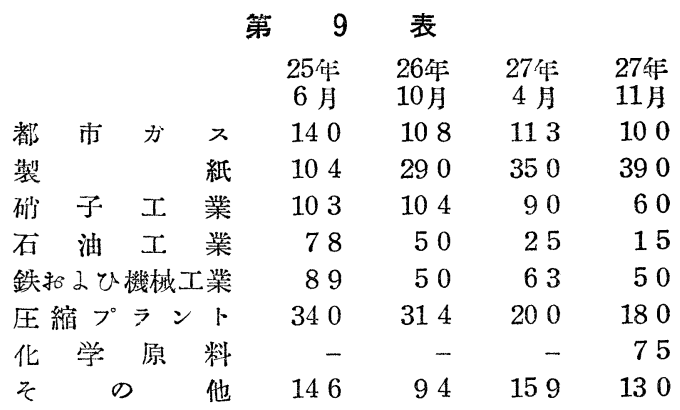

矿子工業における天然カ スの優秀性と安全なことは 既に一般に詔識されているか，東京製墤工業（秼）の こときは，石炭カスに比し製品か透明にてきるのて評 制かよい。

以上のような熱源，動力源として利用のほが最近 アセチレン柔合成化学工業，むたはメタノール工業， 水素を利用与る硫安，尿素等の肥料工業就よひ副業と して宝石製造なとに利用することに着目せられ，既に 新舅市には日本无斯化学工業株式会泟かメタノール生 座工場を趛設し，昨年狄より气の一部の製品を市場に 販売していること前迅のと抢りてある。一方同市日本 軽金属株式会社新鼠工場冈においては，天然カスの電 孤分解によるウ ているのて やふては市場品として期待されている。

新舅市にはさらに天然カスを原料とするカーホンブ ラ,ク工場も建設され，好成䋶て操業している。この 装置は天然かスと重抽索㴊用するものてある。

次きに天然が井には窒素分を含有する水をともな らものあり,かかる生産地（諏訪盈地，山形盆地およ ひ琵琶湖なと）の農民は肥料として活用している。が スに塩水をともなら千炗県ては，これに含有せらるる ヨード分に着目し, 戦命よりこれか换集法を研究し, 戦後には輸出品として年間約 1 億内の外貨を獲得して おり，政府もこれに刘しては可及的融賀するなとの援 助をしている。最近はこのヨー・゙探收法にイオン交換 澍脂利用の新しい研究か進められ，千葉に比してョー ド含有率のはるかに低い東京カ ス田 $(\exists-r 20 \mathrm{mg} / 1)$

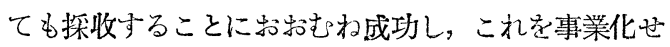
ルそして世人の注目を引いている。促つて千葉県ては

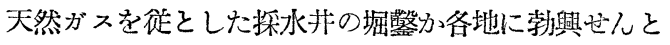
している。

\section{石泊鉱業の趨勢}

昭和27年度にむける石㣙鉣業は, 前年度に比へまま り変化はない。すなわちわか匡て最大の石澌を兴出し 
ている秋斗県の八橋油田においては，特に高野（こう や）特よび外旭川地区に拉いて，前年に引続き順調な 開発か行われた。その他の油田，たと忘は八森, 院內， 庄內, 新㡽, 西山なとに掠いても大体前年度と等しい

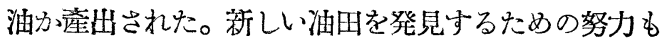
続けられ，何本かの款堀か行われた。このらち山形県
の新庄附近に堀られた堀之內 1 号ては油曆に遭遇し， 月下詳しく地下の状熊を調へつつある。次きにわか国 の石油の大部分を產出する帝国石油会社に括ける警井 状況（昭和27年 9 月 6 日現在）を第10表により知るこ とかてきる。

探油方面に乱いては從来よりるカスの浪費を防くこ

\begin{tabular}{|c|c|c|c|c|c|c|c|}
\hline & & & & 10 & & & \\
\hline 種 類 & 坑 & 名 & 杬 & 目 的 層 & $\begin{array}{l}\text { 予定深度 } \\
\mathrm{m}\end{array}$ & 開坑月日 & 現征深度 \\
\hline 試 掘 & 小栗山 & 3 号 & 新 潰 & 椎谷啳, 寺泊層 & 1,800 & 827 & 491 \\
\hline$"$ & 五日町 & 1 号 & " & " & 1,300 & 818 & 330 \\
\hline " & 松之山 & 4 号 & $"$ & 凝灰岩層 & 1,000 & 76 & 961 \\
\hline " & 掘之內 & 1 号 & 山 形 & 川層 & 1,500 & 710 & 806 \\
\hline " & 㧒 田 & 6 号 & 秋 田 & 桂根層, 船川層 & 1,500 & 712 & 1,144 \\
\hline$"$ & 木戶冯 & 1 号 & " & 女川層下部 & 1,000 & 716 & 213 \\
\hline 探 掘 & 院 内 & 121号 & " & & 1,500 & 528 & 1,412 \\
\hline$"$ & 八 橋 & 73号 & " & 10 & 1,850 & 720 & 1,350 \\
\hline$"$ & 外旭川 & 50 号 & " & $"$ & 1,850 & 722 & 1,436 \\
\hline 探 掘 & 院 内 & 122号 & " & 内 $I I$ & 900 & 726 & 915 \\
\hline$"$ & 外旭川 & 51号 & " & 9 & 1,450 & 730 & 1,395 \\
\hline " & 外旭川 & 52号 & " & $"$ & 1,450 & 828 & 996 \\
\hline " & 外旭川 & 53号 & " & " & 1,500 & 93 & 160 \\
\hline$"$ & 高 野 & 82号 & " & " & 1,600 & 819 & 1,380 \\
\hline ガス卡 & 新 淣 & 46号 & 新 淣 & $\mathrm{E}$ & 365 & 827 & 362 \\
\hline
\end{tabular}

とか問題となり，油層中に含まれる自然のェネルキを 最人に利用する方法力樍極的儿実行されるようになつ た。あるいは有效なフートハルフを使用して能率よく 探油するカスリフトも探用されるよらになつた。1本 の井戸て二若を同時に探油する方法か高野地区に颃い て探用され原油の探油経費を低下させる方面へも努力 か続けられている。地下にある自然のェネルキのみて は地下に多量の油力䂝留するのて，地上よりェネルキ を神給してさらに多くの油を回收する方法か行われ る。この最当樍極的な方法てある水攻法分八橋㣙田雄 物川地区て行われ，前年度より試験的に㣙㸴に呅し水 か位入された少，本年度に至つてその成果力顕渚に現 われるに至つた。すなわち 8 本の判より水を注入し た結果高の附近の探油井に执いて從来の数倍の量の油 か探油されるようになつた。この方法の成功はわか国 の開発し得る石油資源加澊加したことを意味し，石油 鈗業に抢けるすこふる重要な問題てある。

その他の事項としては，27年 6 月より新しく石油お よび可燃生天然がス資源開発法力施行されたことかま けられる。これは地下資源量最も有效に開発すること を目的とするものてある。これによりわか国の石㣙資 源加從来よりさらに樍極的に，か力能率的に開発され ることか期待される。

\section{石油精製業の䞶勢}

諸產業の振興にともなつて潭加する石油製品の需要 に応之，かつは医際支の立場から外貨の節減に寄与 するため，原油を輸入し国内て精製するといら基本線 に沿つて，昭和25年初頭上り活動を開始した石油精製 業は順調な発展の過程を経て，昭和27年に竹いては原 油処理能力の搪充，閏骬油の製造を主作とする第一期 工事を完了して，さらに精製費の合理化を目的とする 精油設備の近代化の一環をな寸接触リフォーミンク， 接触分解裝置なと高オクタン佂揮発油製造裝置建設一 の第一步を踏み出したのでつた。

昭和27年12月末の原油処理能力は約 $131,000 \mathrm{bbl} /$ 曆 日て前年末の $31 \%$ 增，1 12月間に欮ける石㣙の軨入 量は $4,449,437 \mathrm{kl}$ て前年に比し約 $56 \%$ 堌，生無量は 4,707,128kl て前年に比し56\%堌てまり，年間 $5,700,000 \mathrm{kl}$ の石油製品需要量に刘し 82\% の供給力を 示すに至り，本邦諸產業振興に笴与寸る基幹逢業とし ての実質的な內容をも具備するに至つた。

(1) 設備の拡充

揮発油の替在需要を予想して各製㹨所に岕ける原油 処理能力は逐年愐加の倾向にあつたか，卙換重油の需 要堙はこれに拍車をかける結果となり, 太平羊岸ては $41 \%$ 瀷の $110,485 \mathrm{bbl} /$ 曆日, 日本全国ては約 $131,000 \mathrm{bbl} /$ 
曆日に及び，日本石油精製横浜，三菱石油川崎，大協

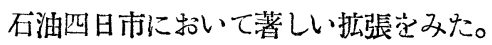

また太平洋岸製油所再開以来の主要課題てあつケた溶

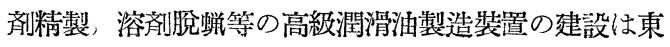
亞燃料工業和歌山製油所に和けるプロパン脫歴, フェ ノール抽出裝置の完成により一応完了し，潤滑油の円
滑な需給と品質向上に寄与するところがあつた。

全国主要製油所の12月末日設備能力は第11表に示寸 と衫りであり，前年に比し著しく充実されている。暦

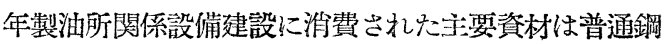
鋼材 $5,307 \mathrm{t}$ ，セメント $3,422 \mathrm{t}$ てあつた。

第11表 製油所設借能力表

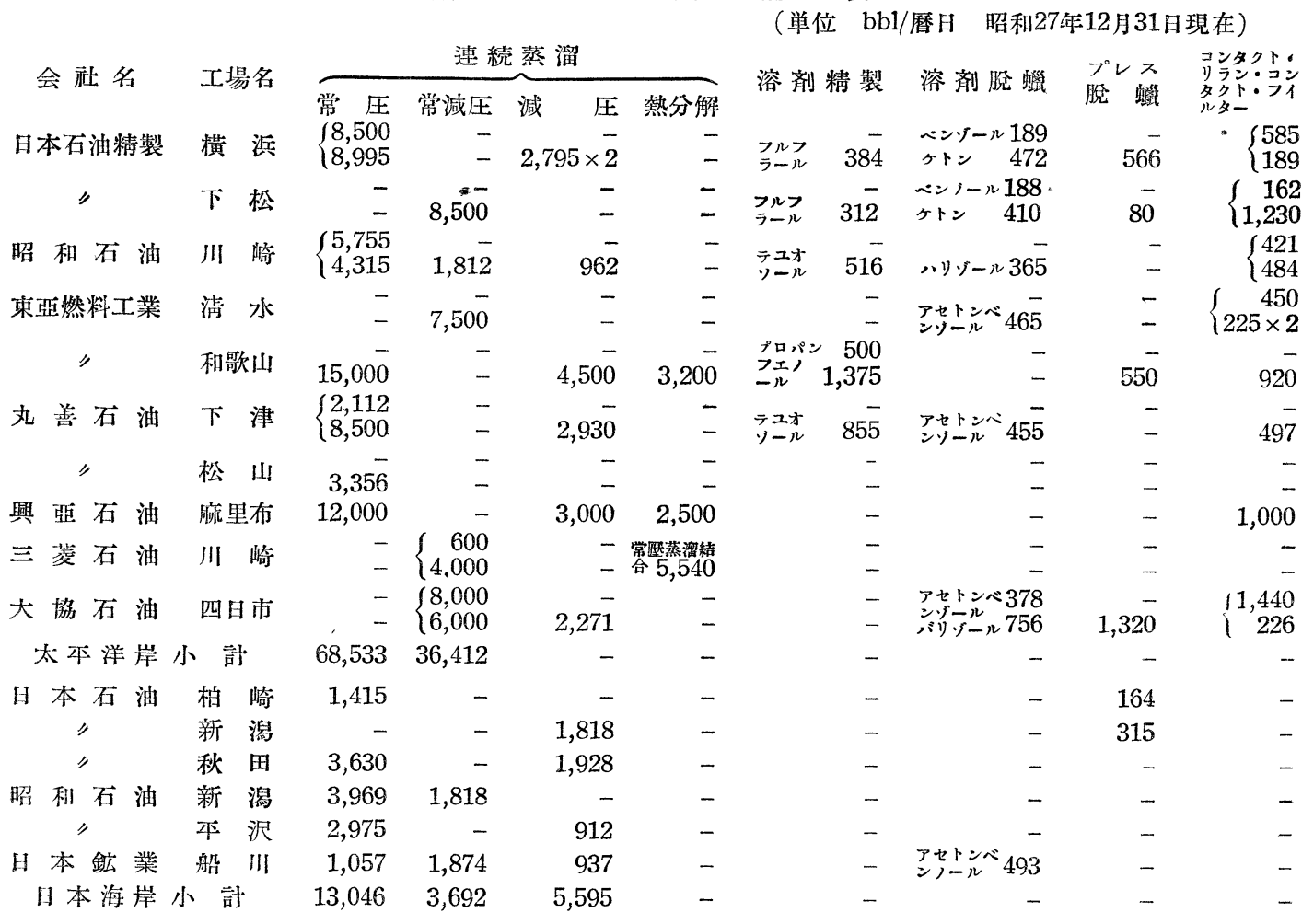

$$
\begin{aligned}
& \text { 原油名 } 1 \sim 3 \text { 月 }
\end{aligned}
$$

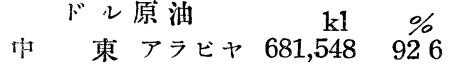

$$
\begin{aligned}
& \text { * 国 サンノーキン } 13,46018 \\
& \text { * 国 プラセりタ } 13,017 \quad 1.8
\end{aligned}
$$

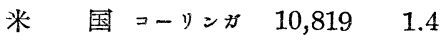

$$
\begin{aligned}
& \text { ニューキニア クラモノ } 16,622 \\
& \text { 訂 } \\
& \text { ポンド原油 }
\end{aligned}
$$$$
\text { 北水れりヤ131,386 } 522
$$$$
\text { 中果クェイト } 83,655333
$$$$
\text { ニューギー クラモ゙， } 23,461 \quad 9.3
$$$$
\text { 北示几不オ 一ヤハール }
$$$$
\text { スマトラ アンコェント } 3,422 \quad 1.4
$$$$
\text { 計 }
$$$$
251,581 \quad 100.0
$$$$
\text { ( } 255)
$$

\section{第12表 昭和 27 年輸入原泊実綪}

\begin{tabular}{rrrrrrrr}
$4 \sim 6$ 月 & \multicolumn{2}{c}{$7 \sim 9$ 月 } & \multicolumn{2}{c}{$10 \sim 12$ 月 } & \multicolumn{2}{c}{ 合 } & \multicolumn{1}{c}{ 計 } \\
$\mathrm{kl}$ & $\%$ & $\mathrm{kl}$ & $\%$ & $\mathrm{kl}$ & $\%$ & $\mathrm{kl}$ & $\%$ \\
819,986 & 94.5 & 893,985 & 946 & 724,984 & 970 & $3,120,503$ & 946 \\
13,537 & 15 & 26,746 & 28 & 8,485 & 1.1 & 62,228 & 19 \\
13,081 & 15 & - & - & 13,973 & 1.9 & 40,071 & 1.2 \\
6,167 & 0.7 & 7,883 & 08 & - & - & 24,869 & 0.8 \\
16,125 & 18 & 16,438 & 1.8 & - & - & 49,185 & 15 \\
868,896 & 100.0 & 945,052 & 1000 & 747,442 & 100.0 & $3,296,856$ & 1000 \\
& $(76.1)$ & - & $(729)$ & & $(72.9)$ & & $(74.1)$ \\
150,619 & 552 & 214,661 & 61.4 & 168,038 & 603 & 664,704 & 57.7 \\
108,009 & 39.6 & 109,923 & 314 & 85,627 & 30.7 & 387,214 & 336 \\
14,162 & 52 & 25,131 & 72 & 24,830 & 90 & 87,584 & 76 \\
- & - & - & - & - & - & 9,657 & 08 \\
- & - & - & - & - & - & 3,422 & 0.3 \\
272,790 & 100.0 & 349,715 & 1000 & 278,495 & 1000 & $1,152,581$ & 100.0 \\
& $(239)$ & \multicolumn{2}{c}{$(27.1)$} & & $(271)$ & & $(25.9)$ \\
141,686 & $(100.0)$ & $1,294,767$ & $(1000)$ & $1,025,937$ & $(100.0)$ & $4,449,437$ & $(1000)$
\end{tabular}




\section{第13表 精製業者, 供給会社と供給原油の関係}

会社名原油名供給会社

日本石油精製 サウヂアラビヤカルテックス 興留石油サウチアラビヤ 大協石油サウヂアシビャ 柬亞燃料サウチアラビヤ 丸善石油 サンノーキンバーレーュニオン

(2) 生 兴

a. 原油の粮大 年間に輸大された原油の種類並び に数量は第12表にしめすとおりてある。原油の輸大傾

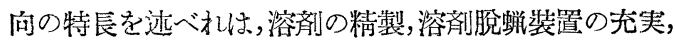
揮発油，重油等燃料油の需要堙加の影響などにより， サンノーキンバーレー,プラセリタ,コーリンガ, ジ ヤパノール，クラモノなとの無蜼原油（主としてナフ テン系) から, 中東原油 (パラフィン采), および高 オクタン価揮発油收得率の多い軽質セリヤ原油へと順 次移行した。また各得製会邧と供給会社並びに輸入原 油の種類との関係は第13趇に示すとおりである。

b. 生產と需給 諸産業の振㖵にともなつて石油製 品の消費は昭和25年 $2,040,000 \mathrm{kl}, 26$ 年 3,330,000kl そ 年々湓加してきたものの，依然として統制は続けられ てきたか，国際情坳の小康と外貨資金事情の好転，石 油精製策の充実により需給状況力洝定し円滑化される に特よび，7月1日に至つて待望の統制発止のときを むかえるに至つたことは特筆すべきことといえよう。

\section{第 1 図}

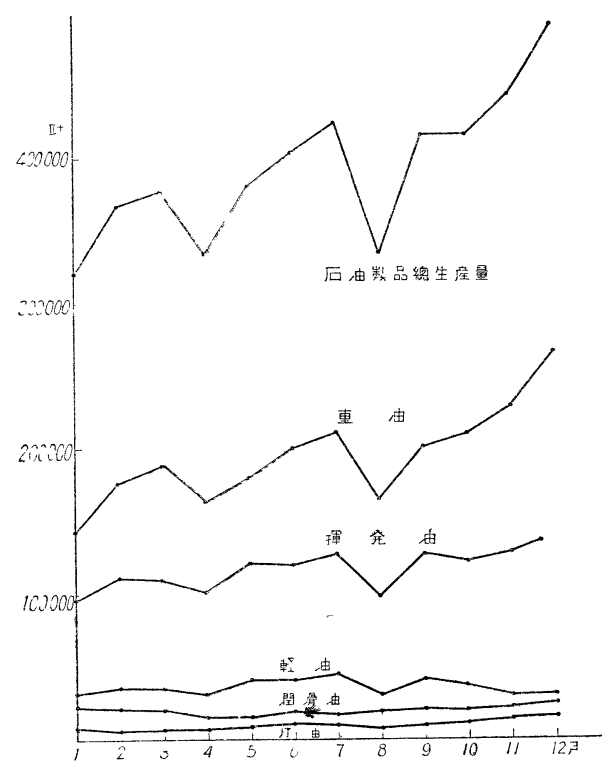

会社 名

卆善石油七

三菱石油

昭和石油

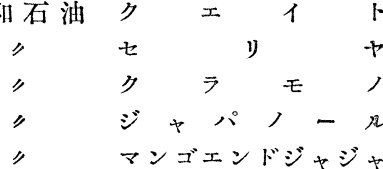

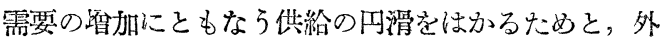
貨の節減と，原油の輸大国內精製の方針は坚持されて いるのてあつて，原油の処理量は国蓬原油を含めて 1 ～3月 1,078,819k1 (75,500bbl/暦日), 4 6 月 1,120,31 $6 \mathrm{kl}(77,500 \mathrm{bbl} /$ 曆日)，7〜9月 1,180,847kl (81,000b b1/曆日) と順次潭加し，10月上降石炭ストライキに原 因して重油の需要は急激に浯加し，自動車の潭加によ る揮発油の需要の伸長とあいまつて，原油の好理量は 1,322,458kl(90,500bbl/曆日)にむて溜加した。年間に おける原油の処理量は 4,702,440k1 ですり，主な製品 の生童量は第1図のと和りである。

c. 浬転資材 上記の生戈に必要とした主要運転登 材と電力量の曆年消費実續は下記のとおりてまる。

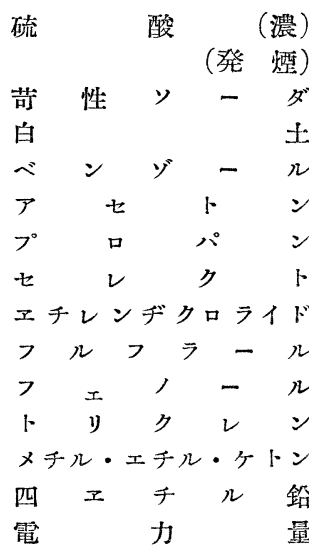

$39,156 \mathrm{t}$

2,285 "

2,235 "

$11,930 "$

$700,564 \mathrm{~kg}$

409,063 "

278,316 "

114,017 "

132,724 "

56,022 "

35,450 "

$5,000 "$

2,654 "

$2,484 \mathrm{t}$

$74,347,415 \mathrm{kWh}$

(3) 設備の近代化

7 月 1 日石油製品の統制発止以後不油業界は販売競 争の段階に入り，石油精製業の合理化か泌然的に要請 された。すなわち第一に生産コストの切下けてあり， 第二に品質の向上てあつて，生產ュスト切下げの目的 に沿うためには量產による単位当り精製原価の低減と 同時に設備効率の向上をはかることが必要でり，品 質向上の目的を果寸ためには技術の向上ととるに窮䄚 においてて近代的精油設備の新增設を必要とする。高 
級潤滑油製造裝置については一応の整備をみたので， 高オクタン価揮発油の需要に応するため，接触りフォ ーミンクや接触分解装置の新設に各精製会社の計画は 集中し(第14表参照)，先進匡米国の精製技術の導入が 活潑に促淮されるに至つた。

技術導入の队容は一样に特許実施権の供与，裝置の 設計，建設。蓮転の援助なと全般に及んているか，所
要資金の調達方法については日本石油精製, 興亞石油， 東亞燃料等は外国資本との提携による近代化計画の一 環としての外資導入により，丸善石油，三菱石油，昭 和石油，大協石油等は禨械裝置の輸入資金を日本銀行 別口外国為替借付，建設費を閉発銀行の融資なとの国 內調澾に依存しているの子本邦石油精製業の特色の一 端を示すものとして興咮梁い。

\section{第14表 高オクタン佂揮発㴼製造裝置建設計画}

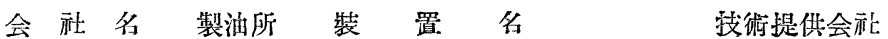

日本石油精製横浜流動式接触分解

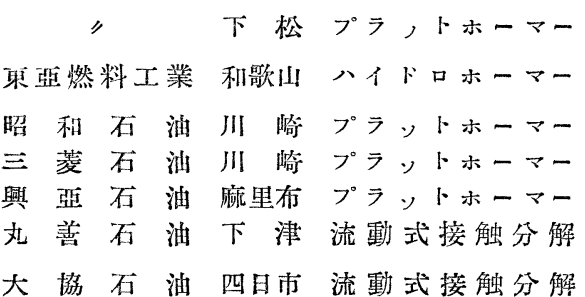

大 協 石 油 四日市 流動式接触分解

$$
\text { " ポリメリゼイション }
$$

(能㤎1/曆日) 完成予定 5,050 昭们 26 年 6 月末 1,300 28年12月末 4,200 29年 6 月末 1,300 29年 2 月末 1,300 29年 4 月末 28年12月末 2,700 29居 6 月末 29年 4 月末

173

\section{ペトロケミカルスの進展}

石油扢よで天然ガスを原料とする化学频品の数はこ れまでに 2,500種以上を数宇，これらの製品の需要は む寸ます榎加する一方である。なかでもェタン，エチ レンから得られる誘導体の数は着実に漂加し，プロピ

\begin{tabular}{|c|c|c|c|c|c|c|c|}
\hline 芳香族系 & 1951 & 1950 & $\begin{array}{l}\text { 第 } \\
\text { 前年度に } \\
\text { 対する篞 } \\
\text { 加率 \% }\end{array}$ & 肪 & 1951 & （単位 $1, C$ & $\begin{array}{l}001 \mathrm{lb}) \\
\text { 前年度に } \\
\text { 対する筧 } \\
\text { 加率 \% }\end{array}$ \\
\hline アルキル芳香族 & 432,139 & - & - & エタン, エチレン & $1,710,158$ & $1,821,893$ & (6 2) \\
\hline ベンゼ ン & 234,521 & 72,927 & 221.6 & $フ^{\circ}$ 口 パ & 973,561 & 998,842 & (2.5) \\
\hline クレシル酸 & 20,886 & 16,080 & 26.8 & プロピヒン混合物 & $1,141,635$ & 694,047 & 645 \\
\hline ナフテン 酸 & 38,528 & 24,684 & 56.1 & ブタチェン & $1,221,229$ & 610,056 & 1002 \\
\hline $1 \pi x=$ & 408,295 & 329,112 & 24.1 & ブ チ レ ン & $1,136,188$ & 641,072 & 77.2 \\
\hline + $シ \quad \nu \quad ン$ & 464,416 & 449,587 & 3.3 & ブタンその他 & 451,219 & 387,521 & 164 \\
\hline そ $\quad$ の & 5,190 & 532,571 & - & そ の 他 & 267,982 & 356,669 & $(249)$ \\
\hline 訫 & $1,603,475$ & $1,424,461$ & 12.5 & 訫 & $6,901,974$ & $5,510,100$ & 252 \\
\hline
\end{tabular}

の生產は含まれていない。

最人の伸長を示したものはベンゼンで，1950年の 10,000,000gal の生産に対し実に 3 倍の $32,000,000 \mathrm{gal}$ か1951年に生座されている。これは主としてプラット ホーミング，接触リホーミングの墰設によるものであ る。その最大の消費はスチレンの製造で 8,200 万gal に達し，つでフェノールの合成, ナイロンアアン 之，合成洗剤，D D.T. の製造に消費されている。脂 肪旅てはプロピレン，ブタヂェン，ブチレンの生產が
レン，ブチレンのそれの約 2 倍に達している。

石油化学工業力㵊子発達している米国についてみ机 1950年度の生產を $25 \%$ 上迴る 85 億bbl に達している。

著しく增大した。プロピレンの增加はイップロピルア ルコール，プロピレングリコール，グリセリン，テト ラプロピレン重合物， D-D の生座の睢加によるもの で，インプロピルアルコールの75\%はアセトンの製造 に向けられている。グリセリンの生産は全グリセリン 生產量の約18\%に達し, テトラプロピレン重合物は主 として合成洗威の製造に消費されている。ブタチェン の增加は合成ゴムの再閉によるもので，G.R S. ニト リルコムムの製造に消貟きれ、ブチレンはブチルゴムの ば，第15表に示すごとく，ペトロケミカルス生産は この中にはアンモニア，アンモニア化合物および硫黄 
製造に消費されている。むたその一部はブタノールの 製造に用いられている。その他クレシル酸,ナフテン 酸の生產量斗藷しく潭加した。

その他住目すべきものは天然ガス，精製ガスからの 硫黄の回收で, 硫黄の需要が著しく䎸加し, 年々不足 している。すなわち1951年度は $5,722,000 \mathrm{t}$ の生產に 対し消費量は 5,823,000 t か㳅足している。

まだ天然ガス，精製がスからの硫黄の回收はわずか であが，多くの增產計画心なされている。1952〜 1955年の間に抢ける38の潭產計画中天然がスからのも

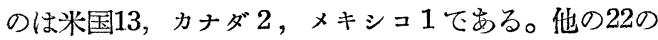
計画は精製がスからのもので米国15，英国 3，アルゼ

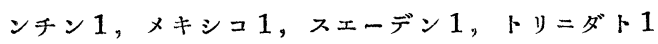
そなつている。

石油化学会社の新規計画としてカーバイトの大宗で ある Carbide \& Carbon Chem. 社咭よび Monsanto Chem. 社が天然ガスを原料とする Sachse 涯による アセチレンの製造計画を建てていることは興味があ る。オキッ法によるアルコール製造の工業化を EssoStandard Oil 社と Du Pont 社分行い, 前者はノニ ルアルコール，後都はリメチルへキ少ノールを製造， している。 Jefferson Chem. 社はモノェタノールア ミン,ヂェタノールアミントリエタノールアミンを 製造する米国の第 3 番目の工場を新設し，3月操業を 開始した。Monsanto Chem. 动はプロピレンとべン ゼンからキュメーンを経てフェノールを合成する装置 を計画し 1954 年操業開始といわれている。その他 American Cynamide 社 のアンモニア特よびアクリ ルニトリルの製造，W. R. Grace 社のアンモニアお よび空素化合物の製造, Carbide \& Carbon Chem. 社の年間5,000 6000 万1bのポリエチレン, 500〜1,000 万lbのエチレングリコールの製造計画がなされている。

カナダに捻いては Canadian Chem. ガェドモンド に世界最大のペトロケミカルスおよび化学纎維の大工 場を建設中て，プロパン，ブタンを原料とし，これを 酸化し，アルコール，アルデヒド，酸などの酸化製品

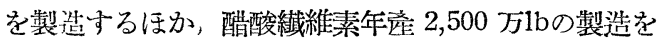
計画している。また Canadian Industry もエドモン トンにポリェチレン年間 $6,000 \mathrm{t}$ 製造の計画を建てて いる。その他 1 日約 1,000 万 $\mathrm{ft}^{3}$ の天然がスを使用しア ンモニア年産 $90,000 \mathrm{t}$ を製造するものがあり，これ を原料として連続式 “Biazzi” 硝化涯により=トログ リセロールを製造する火薬工場を建設中である。

英国に招いては British Petroleum Chem. 社力彩 たにイップロピルアルュールの製造工場を建設中であ
るほか，仏国に私いては、Ethylene Plastic 社が年 產 $2,000 \mathrm{t}$ のポリエチレンを製造する工場を建設中で ある。

わが国の石油化学工業は欧米の警異的なぺトロケミ カルスの発展に刺钱され, 天然ガスの酸化によるメタ ノールの合成，電㧓分解によるアセチレンの製造，天 然ガスから石膏法による硫安の製造力計画されたか， まだ研究調查の段階ですかに日本がス化学工業株式 会社か: 9 月からメタノールの合成を開始したに過ぎな い。同工場の 27 年 $10 \sim 12$ 月の精製 メタノールの生產計 画は $400 \mathrm{t}$ である。輸入アルケーンを原料とするアル キルベンゾール系合成洗肪は軌道にのり需要力增大し つつある。

最近ポリエチレングライコール系非イォン表面活性 鼡の優秀性か洛方面から着目され，輸入ポリエチルグ ライコール，ポリオキシェチレンダライコールを原料 としてポリェチレングライコール系非イォン表面活性 剤を合成し，ニ，サンノニオン，エマルゲンなとが市 販されている。

\section{石油に関する研究}

まず国内の石油関係の研究発表を通観すると，各不 油会社の能力充実にともなつて研究はますます活潑化 している。発表される研究は前年と同じく潤滑油関係 のものが主力であるが，高オクタン価がンリンの必要 にともなつて接触分解関係の研究も先の数を墂してき た。

試験分析関係では，日石の松田氏は原油評価に使用 する牛自動式覓沸点蒸溜裝置について報告した。日大 工の市川氏は前年に引続き分解ガッリン中の共䡉ヂオ レフィンの定量法を研究し, 前年報告の油脂のデェン 価測定応用法の改良について報告した。

分離関係では吸着分離法，尿素附加物抽出結晶法な とは研究の常套手段として各方面で利用されている が，たと壳ば東工大の山崎氏は灯油溜分から nードデ カンと nートリデカンを尿素抽出結晶法で抽出して種 々の誘導体合成の用に供した。東北大非水研の松木氏 は液体アンモニアで灯油の溶昘精製を行つている。氏 らは低溫タール酸性油の液安抽出については多数の報 告をしてきたか，石油溜分に対するものは內外を通じ てその数は少ない。単一特よび連続抽出の結果，抽出 量は $10 \%$ 內外で，酸と可䌞化物は容易に抽出されたが 不飽和炭化水素々硫黄化合物はあまり抽出されない。 芳香族化合物は $50 \%$ 內外方抽出された。同じく非水研 の石田氏はへプタンートルォール一液安系の本衡につ いて報告した。 
クランキングに関する研究は最も活潑で報告の数も 多い。早大の山本氏は，接触分解き吸着脫色の基礎研 究として, シリカーアルミナ系蚛媒による種々の炭化 水素の高溫気相吸着実験を行つた。触媒には吸着中心 と反応中心か活つて，活性化吸着たけて分解率脫色 率決定されるのではなかと推論した。東工人原氏 は接触分解機構の定說てあるプロトン活性說の矛盾を 指摘し 渐機構說を発表した。触蝶には吸着中心と酸 性中心（反応点）心むつて，それそれ量的な面と質的 な面を支配卞西。同じく氏ら结シリカーアルミナ系触 媒のォレフィン雷合能を測定して前訟を裏附けた。東 工人の池辺氏に接触分解触媒の再生劣化を各種の为の について検討した。酸性度 表面積特よび活性化吸着 能の変化を測定した。さたシリカアアルミナ混合ゲル

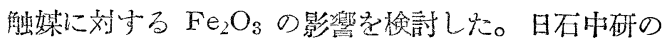
秋山氏は 3 種の活性白土でフラヒヤ灯油の接触分解を 行い，活生化條件を梌討し，京衣活性子酸性度特よび

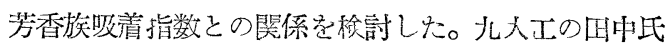
心芳香族炭化水素の接触智分解定研究して，種々の側

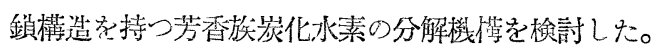
北大工の人塚氏は，流動燐酸触媒によるプロペン，ブ テンの共重命の子備実験として，固休燐酸触媒による 共重合学行い。共重合作のープテンが主として生成卞

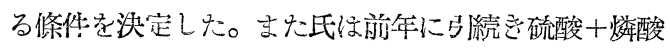
混酸触媒の正フテテンの重合堂研究し，混酸触新の寿命 について報告した。

他に早大の石川氏は登酸ピ，チの接触乾溜油の成分 について報告した。浪速大工の吉村氏はペンシルハニ ヤ柔マシン油の酸スラ，ヂを分析した。

海外の研究はきわめて多く個々の說明出省略する が主な多の拾光は次のとおりてある。分析哭係て は個々の炭化水素の檢出なとカ洌年のごとくに2られ るが，その方法としては精密蒸溜，クロマトグラフ四 着などて分離し，各程分光分析法て確認，定量するも のか人多数てある。蛍光物質の分析にはり逨の 2 殸告 かあるが一方ては溶用抽出とクロマトグラフ吸着て 分離してヒチューメン中の蛍光物質は重質のものほと 蛍光は長波長になることを認めた。他の報告で液状 とクロマトグラフ荃中の蛍光波長を測定して，液の場 合は油の型によつて最强波長の現われるに対し，塔中 ては底部に展開されるものほと波長名浢いことを証め ている。D. W. Criddle 氏はクロマトグラフ分析に おいて晎種の炭化水素の境界面を可視にするため, 紫 外線照射で発光する油溶性色素を使つた。他に灰分分 析，硫黄分測定法なとに関する報告かある。
クラ,キンキ関係では, クキックング機檴の研究とし 一触媒面に跨ける重水々炭化水素の水素交換の研究少; V. C. F. Holm 氏や R C. Hansford 氏なとにより 報告されている。 R C Zabor 氏らは触媒の正パラフ ィンの吸着を研究L，L W. Gamble 氏は触媒中の $\mathrm{Mg}, \mathrm{Zr}$ 分分光分析て定量 L， B V. Klimenok 氏ら は触媒上に附着寸るコークスの研究に電子顕微鏡是使 用した。クラキングの研究は枚挙にいとなないか， 特殊なものの一つに R C Archibald 氏の高溫，高 空間速度下の実験台要る。高周波加熱老利用して $700^{\circ} \mathrm{C}$ むてに試料を $1 / 100$ 秒て加熱し，クメンとセタ ンの接触分解を行い,カーホン生成量, 触蝶の許容粒 度について論じな。他に炭化水素变換, 脫硫などの報 告も多数に昇るか特に目渐しい为のもないのて割愛す る。

\section{潤滑油に関する研究}

潤滑油に閣する研究を調へてみて感じられること は，潤滑油の性状とか潤滑作用なとについての基礎的 研究か,盛しである一面，潤滑油添加剤の進步と相まつ て潤滑削の実用性能をてきるたけ奏用條件の近くて事 験公的にあるいはェンチンテストによつて評価しよう そする陚み分活潑となつていることでる。グリース

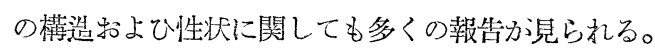
特許の件数からい之は，各種澗滑油添加剤茥含めて含 添加剤㵎滑油の製造岕よびグリースの製造がきわて 多数あり，潤滑油の精製法护接触脫硫に関するむのな とかこれに続いている。以下にます国内の業績を速 べ，次いて海外のそれを概說する。

潤滑油の合成に関係したものとして、ライォン油脂 の富山衒一氏らは拡散ポンプ油としての高級アルコー ルとナフタレンとの白土による縮合油の最適製造條件 を調べを結果を，阪大理化の野桜俊一氏はアルキルビ フェニルを合成してこれが搪散ポンブ油として充分使 用に耐光得ることを示した。九大工の加藤常太郎氏ら は油脂，生ゴム等の乾溜油をアルカリ熱処理すること により乾溜油の $\mathrm{AlCl}_{3}$ 重合の結果か著しく良好とな ることを認め灾。

吸着珮檴製に関し，早大工の山本研一氏らはシリカ アルミナ采吸着刘の脫色能と比表媔積との間には相関 々係か認められないか，吸着肪の高温脫色能とベンゼ ンや nーープタンの高溫吸着能との間には相当な関係 か存在することなとを述へ，日石中研の水谷嘉之氏ら は，各種吸着剤の比表面樍を測定しそれらの有効比表 面積と芳香族吸着指数との相関性を示し，むた吸着郕 表面の吸着性を表わす尺度としてアルュール吸着指数 
を提案した。さらに氏らは登吸着剤中の含油量を予知 する方法として多油価を提案し 白土類の吸油何に関 し報告した。

聞滑油の性状関係ては，日石中研の高橋幹雄氏力石 油高沸点溜分の粘度一粘度溫度一沸点間の相関及係か ら実験式を誘導しこれを計算図表の形て示した。日石 新舅製油所の渡辺義雄氏ら治数種の流動点降下剤の性 能試験結果を報告した。潤滑油の安定性女るいは実用 性能に関係のあるものては，日石中研の片山寬氏らが エンデンテストによつて各種自動車エンチン油の性能 の此較試験を行つた結果牤よび実用試験結果に及ぼす 機旅的困子の影響について迹へ，な打 Sohio 酸化磨

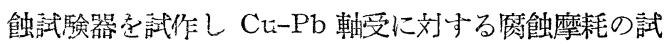
跧に用い得ることを示した。鉄道技研の田野辺視人氏 は客車々軸油の变質污濁化の状熊を追跡しその使用限 界を考察した。日立の高橋治男氏は日立絕緣油安定度 試験法を設定した経緯，その方法の詳細，試験効果の 繰返性新よび再現性について速へた。また北大工の稻 葉彌之助氏らはタービン油の抗乳化性に関し，抗乳化 剂の添加効果，油の変質に件 万抗乳化性の变化，抗乳 化刘の添加効果，油の変質に伴5抗乳化性の変化 抗 乳化性の異る油の混合効果 ター七ン油のェマルショ ン分離曲線についてて赫告した。

閏滑作用の関係としては，東工人の桜井俊男氏らは

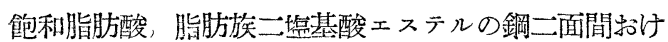
る油膜力整流作用を有与ることを示し，整流作用は油 膜の厚さか数分子愿に達した時に最大となること，摩 擦系数户電子迴析の結果子対照して整流作用一油分子 の方向配列一境界摩擦の間に密接な関係力認められる ことなとを㪍告した。東人理工研の永井雄三郎氏およ び日石中研の宮崎洋氏らは精製スビントル油の靜止摩 擦䋆数 $\mathrm{f}$ に及济寸雾团気の影響を調へ，大気拈よび $\mathrm{O}_{2}$ てはf $\mathrm{f}$ は最も高く，減圧下とか $\mathrm{CO}_{2}$ および $\mathrm{H}_{2}$ ては 低い値， $\mathrm{N}_{2}$ てはとの中位の㑬得られることなとを 示した。日石中研の長野光彥氏以は硫黄柔極圧添加郕 の効果を調べるために，各種 $\mathrm{S}$ 化合物と鉄汾とを反応

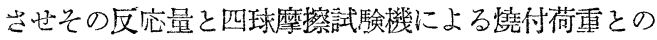
関係を調べた。

つきに海外に括けるは況をみると，精製の関係ては， A. Freund 氏らは各種溶剂による容洲抽出の実験結 果から溶用㨁出の評佂法を远へた。P.Zurcher 氏は

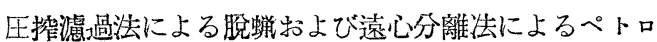
ラタムの分離に関して報告した。HF を使用する石油 類の精製法の成行きはきわめて興味梁いか；ＡＰ． Lien 氏らは閏滑油溜分に適用して，硫黄含量はほぼ
牛分になり粘度指数の向上效果力著しからたことを報 告した。特許の中に表われている HF 処理の件数は 相当数に達しているかう，その中に D. N. Badertsche 氏らの残渣閵滑油に対し $\mathrm{H}_{2} \mathrm{SO}_{4}$ に $\mathrm{HF}$ を加兄て処 理する方法，C W. Mackinnon 氏の同样な HF 添 加による低溫硫酸処理法なと分住目をひく。

分析に関寸るものとして，K.W. Rosenmund 氏 らは Rosenmund-Kuhnhenn 法による沃素洒測定法 を低沃素価の物質に適用てきるように改良し，CＮ Thompson 氏は絕緣油の沃素洒に関連して測定に影 響する多くの困子について検討した。使用閏滑油中の ペンタン怙よびベンゼン不溶性物質の定量に関し J S Wiberley 氏らは A S T M を改変したさミ ミクロ法で好結果が得られることを報告した。閏滑 油郝よび添加洞のスペクトル分析に関して，CＭ Gambrill 氏らは $\mathrm{Ba}, \mathrm{Ca}, \mathrm{P}, \mathrm{Zn}, \mathrm{Pb}, \mathrm{Fe}$ の, J. Hansen 氏らは Fe の, J P Pagliassotti 氏らは $\mathrm{P}, \mathrm{K}, \mathrm{Ba}, \mathrm{Ca}$ および $\mathrm{Zn}$ の定量法について迹へた。 W C Woelfel 氏らは精製油㧍よび抽出油に残存す る痕跡量のフルフラールの定量法について報告した。 組成分析の関係ては，A T Watson 氏力重質油中刀 全芳香族含量をクロマトグラフ法て簡単且つ迅速に分 析しうることを示し，H I Watermann 氏らはクロ マトグラフ法による分析結果と n-d-M 法との比賋検 討を行つている。む心I P 粘庤部会 Master Viscosimeter による動粘度測定に関する恊同実験の成果を 発表した。

潤滑油の性状に関するものては，J.F T Blott 氏 らは粘度一溫度関係を表現する方法として Viscosity Modulus なろ指数を提案し，W. Ruppert 氏恃粘度 一圧力関係について，F W. Hanssler 氏怙よびＳ P. Jones 氏らはそれそれれ間滑油の Thixotropy に関する 実験結果を郝告した。むた R Koetschau 氏各種粘 稠鉣油の色度曲線の型か泛れらの精製度や基と関係か あることを逨へた。

閏滑油の酸化むるいは安定性についての研究は從来 に引続き相当な数にのぽつている。M. R Fenske E らは構造の異る数種の純炭化水素, 炭化水素混合物招 よび閏滑油の酸化試験を行つて陪素吸收速度妨よて酸 化生成物の性状を調べ，そ机らの安定性について考察 した。H Diamond 氏らは独㧱的な装置を用いて $220 \sim 270^{\circ} \mathrm{C}$ に新ける潤滑油の安定性を調へた。D J W Kretlen 氏はトランス油の酸化においてガラスな との固相の存在か誘導期および反庆速度に影響するこ とを示し，さらにホワイト油の酸化におよ添す銅触媒 
の影響を詳細に報告した。D W Sawyer 氏は閵滑 油の酸化に及ぼす各種金属の接触効果を調へ閆滑油に 接する秝械部分には A1 の使用か最適であるとした。 トランス油の劣化は古くから閣題となつていることて あるが，L Massey 氏はこれに関しトランス內部て の油の使用に影響する因子，作動绦件，トランス構成 材質特に銅が劣化に影響すること， BS 148 Sludge Testか安定性評価に良い結果を与えること，油の沃素 価とスラ，千生成量との関係，只の他銅触媒について の実験結果なとを報告した。な怙E. Matsas 氏はガス 機関使用油中の酸化生成物の分析結果を, A Maillard 氏らは蒸気機関の;聞滑油に生ずる変化について，M A Hughes 氏らは多数の潤滑油添加剤の添加効果を 実験室試験によつて調べその結果と L-4 エンテンテ ストとの相関生を述へた。

クリース関係の研究ては特にグリースの檴造に関連 した研究が目立つている。 R. J Moore 氏らは各種 石䩎基グリースの構造と機械的安定性との関係につい て，R D Vold 氏らは石踚鉱油系グリースの Phase Diagram と物理性状との関係および石䲓粒子の構造 を論じ，E.W J Mardles 氏は閏滑グリース中の固 相の構造と物理性状との関係を，B B Farrington 氏はグリース微細構造についての成果を発表した。む た Liーグッースに関し，B W Hotten 氏らはクリー

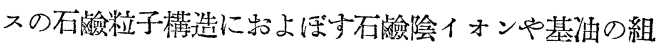
成抢よび分散法の影響谱びにクリースの物理性状につ いて，D Evans 氏らはグリース石險相の構造の変化 による物理性状一の影響を，J A Brown 氏らも同 しくグリースの構造力物理的就よび実用性状と関連か， あることを迹べた。 G V Vinogardov 氏らはグリ 一スの粘度一溫度特性に及ぼす媒体の性状の影響を，

R A H Rothe 氏らはグッースの流動点測定法を, R J Burger 氏らはグリースの防錆性能に関する試 駼結果を報告した。なお C R Singleterry 氏らは 非石鹼型グリースてある Phthalocyanine を含むグ リースか高溫に掠いてきわめて安定性に富むことを示 した。

潤滑作用に関係したものとして，J E Brophy 氏 らは閵滑表面の化学的现象について，C. B Davies 氏は閏滑された金属表面の粗さ乱よび酸化の表面の摩 耗におよぼす影響について，W. Hirts 氏らはステア リン酸膜て覆われた哃表面について境界閏滑條件下て の摩擦倸数および金属の移動におよぼす荷重の影響に ついて, E P. Bowden 氏は各種金属表面間の摩擦 に拉よぼす各種表面膜の影響について，D. Tabor 氏
は境界閏滑および極圧潤滑條件下ての聞滑機構につい て, C G Williams 氏む同じく極圧㵎滑機構につい て, A T. Gwathmey 氏は油一金属界面ての相互作 用従つてまた潤滑作用か雾团気の影響を受けるといら ことについて，R Courtel 氏は無空中て研磨した金 属表面上一の油膜や酸化物償の生成状態を電子迴折に よつて調へた結果について，またＳF Murray 氏 らは数禈の直鎖炭化水素同族列化合物の運動摩擦䋆数 を調へな結果について，それそれ報告した。極圧閏滑 剤の試験に関し，M Pfender 氏は高圧下低涑摺動條 件の菨裝置を，M C Shaw 氏は金属切㓩法による 試験結果を，D K Nason 氏は四球極圧試験器に関 する U S Navy 法の簡易化について速へた。

J I P (Aug \& Sept, 1952) に "Gear Lubrication Symposium”か揭载导れている。その第1部は 菌車閵滑の基碟的な問題を取报つた報交からなつてい る。すなわち，歯車閵滑に拈ける流体力学的法則の適 用に関する媄論，歯車間の油膜の粘度一圧力変化を導 入した耐荷重能式の唀導，Scuffing Fallure を定める

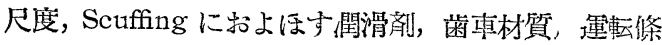
件なとの影響, 歯車の菌の摩耗機構, グラファイトお よびグラファイトを添加した油の耐荷重能，およひ芋 虫菌車に類似した條件て動加される复鈴田板表面の摩 耗沽よび点蝕の機榗について逨へられている。第2 部 は歯車閏滑剤の試験法に関係している。Disk Machineによる潤滑剤の試験抢よひ閆滑剤選択について の考察，四球摩擦試験器に上る試験結果と実用試験と の相関性，各種実験室試験の結果から実用性能它評価 することについての議論，I A E Machine用試験

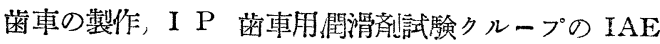
Machine による試験結果，IAE Machine を特に高 速崡車用閆滑剤の試験に用いることについての检討， Hypoid Gear Oil の具備すべき性状,その Full-scale axle による米国および英国試験法並びに他の実験室 試験との相関性，実用試験の必要性とバスの後部車軸 郆ての実用試験結果についての報告か行われている。

\section{內燃機関の趆勢}

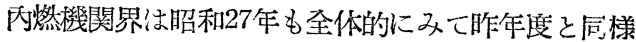
の傾向にすすんている。ピストン式內燃烧関はチーセ ル機関の天下であり，少し馬力の大きいものはほと儿 と排気タービン過給を行つている。タービン式內燃機 関ては大出力航空原動機を完全に打さえたターホシェ ノトむたはターホプロノプかいよいよ発展し性能む一 段と向上し，また航空用以外のカススーヒンもいよい よ害用期に入つた。 
火花点火機関は小型沉用の灯軽油機関，小型および 高速自動車用機関，ーリコプター，軽飛行機，低速の 輸涇機なとの航空発動譏なとに使用されているたけで ある。わふ国ては小型用機関いわゆる農発は今年む 通產省の比較審查なとにより着実に発展をとげつつあ り，從来の蒸発冷却低速栧関はほとんと跡をたち，主 力は中速機関となり，高速機関もかなり現われ，単に 燃費のみならすガ八ナーなども非常によく, 耐久性も 一段と向上した。自動車用としては，高速トラ，ク， 乘用車，小型自動車，自動自転車なとふが゙ンリン機関 て，人型ガンリン自動車の 1 万 $\mathrm{km}$ 公式運行試験が通 産省指導下に行われ，從来よりわか国自動車機関の特 微でつた低燃費以外に，空気濾過器，ビストンリン グクローム鍍全なをて気筒摩耗なとも激减し，耐久性 当向上した。むた小型大紊交通機関として，スクータ 一や禣助エンチン付自転車か非常な樊て普及し，後者 のために各種の小型高速 2 ッイク儿機関か溌展した。 さた航空工業の禁止かとかれた結果, 軽飛行機力試作

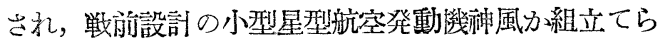
てれ。実用された。

大型トラーク，バス，建設用車両，鉄道の內燃動車 なとはすべて高速ヂーセ几の分野で，わか国てはほと んそ予燃殅室式力用いられ, 性能孔一段と向上し, 床 下ェンチンなとも試作された。運転経咸上鉄道でチー ゼカーか非常に有利となり，新しいチーゼル電気駆 動のヂーボルカーも試作され，いよいよ国鉄ても相当 多く用いられようとしている。漁船用も大型ものより 潮次燒玉かチーゼル化しつつまり, 発電用, 機関車 用, 中小型商船用等の 4 サイクルチーゼルはほとんど

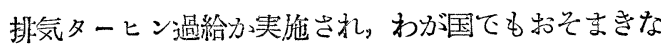
から実用期に入りつつあり，各デーゼルメーカーてこ の試験を行つた。また排気ター七ン過給器も從来のメ ーカーてあつた三菱, 日本重工, 横浜造船以外に石川 島重工，三菱造船ても試作された。大型商船ては，約 10,000HP下の主機は 2 サイクル単衝チーゼルタ注力 て，一部MAN の複働作られ，それより大きい出力 は高溫高圧蒸汽タービンである4 少イクルて非常に 成功した排気ターヒンを大型 2 ッイクル主機チーゼル に利用する研究も寸すめられ、ハーマイスター（B＆ W）社では実用に入り，わか国ても三菱造船て研究試 作か寸すめられ，1気筒 $1,000 \mathrm{P}$ 級のものか成功，近 く実用化されようとしている。をたこのような研究に 対し 4 少イク几機関を $2 \sim 3 \mathrm{~kg} / \mathrm{cm}^{2}$ の高過給を排気タ 一ビンで行い $30 \mathrm{~kg} / \mathrm{cm}^{2}$ に達する平均有效圧力を利用 するような試みも行われている。
ジェノト機関はイキリスを中心としていよいよ発展 し，推力もいよい上増大し， $5 \mathrm{t}$ 級のものか実用さ れ，大出力化とともに遠心添風機型は漸次軸流型にお きかえられ，後者の推力当り重量子前者に匹適するよ らに進步し，さらにブリストル；オリンパスジェト 機関のような高低両圧力系を有するコンパウンド機関 も実用に入り, 推力当り燃費徒来の $12 \sim 13$ を一 挙に08くらいに下げ，また大出力ターホプロ，クも

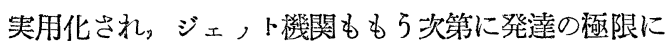
澾せんとしているよらである，わか国ても航空禁止か とかれ，通產省の助成金て大宮富士工業（旧中島飛行 機大窝工場）倠力 $1 \mathrm{t}$ の小型シェ，機の研究試作 をはじめた。発電用舶用のガスターヒンは昨年度以来 の通産省助成金による三菱，日本重工，横浜造船の $2,200 \mathrm{PP}$ 発電用カスターヒン，自社試作の三井造船の 船用ガスターヒンをはじめとし，今年に入り渾輸省禣 助金による三菱造船 $500 \mathrm{P}$ 舶用カスターヒン，自社試 作の石川島重工 $500 \mathrm{PP}$ 船用，日立製作所の $2,000 \mathrm{PP}$ 発 電用，川崎重工の発電用なとのガスタービンの試作が はじめられ、い机も昭和28年中には試運転に入る予 定てある。三菱造船, 石川鳥重工のガスターヒンは航 海訓楝所新造練習船北斗丸に据付けられるはすであ る。

\section{肉燃機燃料の趨勢}

ェンシンに打りる燃堯の基礎となる火花点火につい て，米国り，チモンドのェクスペリメント社の H F. Calcote 氏らは燃料の分子满造と点火ェネルキとの関 係老多数化合物についてしらべ，理論混合気の常圧に

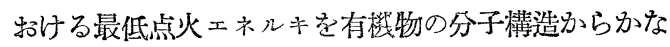
りの精度て推定てきる一般則を見出した。

ノック現率の立場から，英国イムペッアル理工科大 学の A C. Egerton 氏らは冷炎の発生原困となる過 酸化物の生成抢よび分解の行われる低溫点火領域の有 無が，ク性を支配する說をたしかめる目的で,メタ ンの高圧に物ける性質を45気圧まて測定したがここの 領域を見出せなかつた。17気圧で30秒，45気圧て90秒 の点火扔くれか涊り，排気中に相当量のフォルムアル デヒドをみとめた。アセタルデヒド，過酸化ジェチル を $2 \%$ 加穴てもこの領域があらわれないことから，燃 㘹ホンブ中の長い特くれはェンチンては短い扔くれに 対応し，後者ては表面の作用か小さいをめに，後者の 然燒室でメタンか冷炎を発生しノクを抗こすとか あるとした。

英国ハーミンカム大学の A Fallah 氏らは正へプ タンの低溫酸化に対する表面の作用を研究し, 過酸化 
物, アルデヒド,ケトンなとの濃度がある溫度に㧊い て最高値と最低值を示すことをたしかめ, ジインプロ ピルェーテルの冷炎, 熱炎限界との相似性をみとめ た。第一の山に対応する低溫反応ては反応室表面の作 用を弓けるか第二の山は変化しないことから，これら の山は酸化機㦜のちかいを示すものてあるとした。

理工学研究所の山崎氏らは純燃料化合物の酸化にお いてフォルムアルデヒドの生成する時間おくれと溫度 との関係からその活性化ェネルキを分光学的に実測

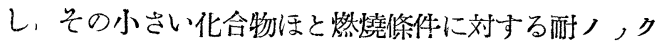
性変化感度の小さいことを明らかにした。

圆体，液体の粒子の燃燒に関して米国鉱山局研究所 の J. M. Kuchta 氏らは石英管中に電極炭素の小片 を抢き，每秒 28-540ft の速度で $900^{\circ} \sim 1200^{\circ} \mathrm{C}$ の䓡 風を揆り燃燒速度を测り，絕文㤆応速度は空気溫度に 関係なく，流速の 047 乘に比例することを見出し た。空気流速がる限界值になると反庆速度は搪散律 速から化学反庁律速にかわり, 炭素表面の溫度は高く なることをみとめた。

東京人学の能谷，磯田両氏は液滴を石英なとの細線 につるし，その蒸発，燃麾時問を七タ之油，正へプタ ン, ベンゼン,ェタノールについてもとめ, 滴の直径, 蒸発潜熱と時間との関係について，英国のロイド氏ら かみとめた当のと同じような結果をえた。

実物ェンジンにに特いては前炎反応について, , 現象に対する興味から多くの研究か行われた。ガッリ ンェンジンにおける初期然橈について米国エチル社の E B Riftkin 氏らは炎面の前に打いて進む化学反応 そ指圧線図の熱力学的解折とを結びつけて研究した。 圧縮比を一定にした燃料試験用単シリンダェンジンに 釣合圧力型指圧器をつけ, 正常点火の実験をくり返し, 前炎反応の出力に対する関係をしらべた。

ジェネラルモータース研究所の W Cornelms 氏ら は笪シリンダェンジンの燃燒室に石英空をつけ, 燃燒 状況を写鲁観測して，前炎反応に対寸る燃料組成，4 ェチル鉛，燃燒室沈積物の影響を明らかにした。

耐ノノク剤の基礎研究には立記 Egerton 氏らの金 属および金属酸化物の過酸化物に対する分解能の実験 がる。 ノ，クする條件では炭化水素の燃然中に過酸 化物かてきることから，4エチ几鉆，鉄カーホニ几な との過酸化水素, 過酸化水素×チル, 過酸化ジェチ几 に対する分解能をしらべた。鉛，酸化鉆，タリッム， 酸化タリウム, 銀, 酸化銀は過酸化水素, 過酸化水素 ェチルを分解するが，過酸化ジェチルを分解しない。 鉄カーホニルは気相でこれらと直接に反応するか，4
エチル敛はます分解する。分解能は粒子の性質によ り，その状態にはよらないものて，分解能は耐ノ，ク 性に関係があると論じた。

自動車燃料の而子ノク剤としてアルコールの再吟味 か行われ，米国ノーザンリージョナル研究所の J C. Porter 氏らは, 85 オクタン以下の場合に 1:1 のア ルンール水を補助に噴射寸れは出力価か5 5 10よくな り，水たけの噴射も有効であることをみとめた。シェ ネラルモータース製高圧縮比 $10: 1$ の試験エンシンは 低速拉よび高速でそれそれ 100 预よび 95 オクタン然 料を必要とするが，F-2 オクタン90〜95燃料に $1: 1$ アルコール水を噴射すれは充分で, 出力価の利得はそ れそれの速度に执いて 5〜10および 20〜30であつた。

また, 米国クリーブランド石油社の S J. W. Pleeth 氏らはェタノール混合ガンリンの発熱量とそれを使つ たときの熱効率，オクタン価，走行性能をしらべ，酤 ノ,ク性について 4 ×ル鉆とくらべた。アルコール 然料の異常蒸気圧, 蒸気栓, 始動性について子ふれ礼 た。

エンシン然然窒の沈積物について, エチル柆の $\mathrm{H}$. J Gibson 氏らの研究があ。沈積物による出力損失 について, 燃料組成, 硫黄, 鉛, 潤滑油, 設計, 運転 條件の影響を検討し，吸大混合気の熱的，物理的原困 にもとつく出力減少と，熱効率そのものの低下による 出力減少とか沈積物によつて特きるした。

ジェネラルモータース研究所の L L. Withrow 氏 らは同じく燃堯室沈樍物による自己点火現象を高速度 写傎て観測し, 後も元, 自己点火, 早寸き点火，， クに対応するいろいろの條件でつのェンジンにつ、 てしらべた。一般に燃燒室沈樍物はそれをのそく條件 では燃燒室か固体で充填されるのを防ぐと同時に，自 己点火，强い,ンクをを起し，先れがさらに沈積物を 粗にすることをたしかめた。

ヂーゼルェンジンに怙いても前炎反応の研究か行わ れた。バーミンガム大学の F. H Garner 氏一派は 長年にわたる研究で添加剤のセタン価に対する作用は 燃料の性質によつて暴り，パラフィン燃料は芳香族燃 料よりも感度よく，ナフテン燃料の感度かわるいこと をたしかめた。ェチルェーテルを吸入空気にませると ー40F まて始動てきるようになり，この作用は七タ ン洒の向上との関係がないとした。たとえは過酸化第 3 ブチルはセタン価には有力である力泇動性には無力 である。自己点火溫度力诋く燃燒範囲の広い涯加物か、 有力である。前炎反応における生成物について子燃燒 室からガスを拔き，各燃燒時期における過酸化物，ア 
ルデヒド, 酸素, 炭酸カス, 一酸化炭素, オレフィン を分析した。また CFR およびクロスリーェンジンに ついて排気と燃燒室がスの成分をくらべ，燃料噴射 時期から過酸化物アルデヒドの山があらわれるまでの 時間とセタン価とか関係することを見出した。

エチル社の M. J. Anderson 氏らは実物のェンジ ンによつて燃料の燃堯萑期における性質に対する硝酸

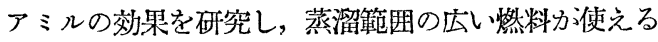
可能性がり，燃料の性質についての許容限界か昿く なる可能性をとき, 燃燒騷曋少なく, 凝固点の低い燃 料力㴗求されても困䧼沈くなると考えた。

定容ポンプによるチーゼ几然料の然燒性か米国鉱山 局実験所の R. W. Hurn 氏らによつて行われた。一 般の市場にある燃料のほか特殊のチーゼル燃料の自己 点火おくれおよびその溫度感度に対して芳香族および ジシクロ化合物㓇きな作用をむつこと, 酸素濃度, 添加剤について子奏験し，ある芳香族燃料では 2 段燃 臸の現象をみとめた。ちかう條件における燃燒性は溫 度むよび圧力の広い領域にわたる燃燒ホンフ試殷によ つてはじめて推測できるものとした。

米国海軍技術研究所の J F. Blose 氏は 4 シリンダ ヂーゼルェンジンの始動泩を支配する要因をしらべ， 特別に始動裝置のないときには $32^{\circ} \mathrm{F}$ 以下ては始動困 蜼でるとした。始動裝置の中ては吸入空気を電気加 熱する方式が広く行われているか，1940年に火災によ る蛞動促進泩がはじまつた これは吸大管に燃料噴霧 を大れ，点火栓て点火し熱する。始動性をよくする最 上のものはジェチルェーテルで，吸大空気にませれは 一15F まて始動てきることを明らかにした。

ガスタービン燃料に関して，この種燃潾の重要な性 質でるる炎速度の研究があ。ソコニバキァム研究 所の R. E. Albright 氏らは炎速と炎の安定性（吹き とび限界）との関係と同特に，点火に要する最低ェネ ルギ，火炎溫度，固体表面の消炎効果について実験し た結果，炎速は溫度の高いほと速くなるか燃料こよつ てちかい，圧力と流速にはそれほと作用されないて規 則性のないこと，アルケンはアルカンよりも一般に大 きな炎速を示し，枝鎮は小さくすることおよう環状炭 化水素に対寸るアルキル枝鎖は一定の变化を与えない ことなとを明らかにした。

ペンシルバニヤ州立大学の P. L. Walker 氏らはメ タン，一酸化炭素，水蒸気の 2 成分さたは 3 成分混合 ガス八ーナ炎の安定性を研究し，メタン一酸化炭素ま たはそれに水蒸気袁加えたものについて，逆火，吹き とび現象と組成との間に直線関係なく，水蒸気量とと
もに一酸化炭素の前記現象に対寸る涑度勾配 $\left(4 \mathrm{~V} / \pi \mathrm{R}^{3}\right.$, $\mathrm{R}$ : 八ーナ孔半烽, $\mathrm{V}$ : 流量) か人きくなり，メタン に対してはわすかなから小さくなることを示した。一 酸化炭素の然堯速度は少量の水分拉よびプロパンのよ 万な水素を発生する成分により大きくなり，ある混合 物の逆火性はその最大燃䇴速度に比例与ることをみと めた。

ロケ，燃料については，米国パーデュ大学ロケソ 卜研究所の C. H. Trent 氏ら々炭化水素に対与る発 煙确酸の反応を研究した。ジェ，ト飛行機の離陸神明 用の然料は主ェンジン然料と同じものか便利でする ジェ，燃料 JP-3 はカッリンと灯油の物理性を子つ

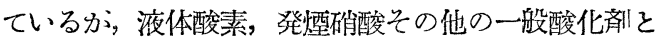
接触するたけては発火しない。ロケ，ト実物エンジン そ同じよらな倭件て発煙确酸を急激に多数の純炭化水 素に加えたときの発熱反応をしらへた。ポリオレフィ ン，アセチレン炭化水素か発火することをたしかめ， 接触時から最高溫度になるむての時間てくらへるのか～ 合理的で，それにより口ヶ，卜用硝酸炭化水素系然料 に適した炭化水素を選ふこことふてきる。発煙确酸，炭 化水素比 $3: 1$ のときに正デカン $340^{\circ} \mathrm{C}$, そ机に $25 \%$ ， $35 \%$ ジシクロペンタシェン倱合物は $154^{\circ} ， 85^{\circ} \mathrm{C}$ で それそれ発火し，後者を45\%ませむものは $8^{\circ} \mathrm{C}$ て発 火することを認めた。

\section{汽力発生と焚燒法の趨勢}

電力は各種產業の基幹をなするのであるにもかかわ らす，わふ国莲業界は征来これふ不足に永らく恼みつ つけて来た。これを克服するため電源の関発に多大の 努力か傾倒されて来たのではあるか，いまだようやく その軌道に乘つた程度て，これふ完成には前途なお一 層の努力と相当の期間を要する吼思われる。雪源 開発に重要な役割を占めている火力発電の湑强につい ては，27年度にはおよそ次きのように刘妈された。

(1) 既設の火力発電所て，蒸汽タービンの出力に余力 のある発雷所はホイ、ラを㣚設强化して㥛力ターヒン 出力の膹加を討つた。

たとえは中部電力名港発雷所において蒸発量 $150 \mathrm{t} / \mathrm{h}$ の挀設 6 缶に対して同容量のホイイラ 1 缶を膹設し, 関

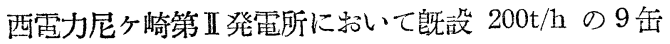
に対して同容量 2 缶を嵧設，飾磨発電所において 160t/h 1 缶を壃設, 東京電力湖田発電所におい、て既没 136t/h 3 缶に対し 120t/h 1缶を堙没し，それそれホ イラの强化を計つたのはこの例てあつて早急に発霆出 力を堙强するのに最も効果のある方策であつた。

(2) これに併行してホィラ,ターヒン, 発雷機等一切 
の火力発雷設備を 拡張して 発電出力の 醰加を訫つ た。

この例として目下据付け中または製作中の主だつた 設備に次ぎの例方岁る。

発雷所名タービン及発電機 ボイラ

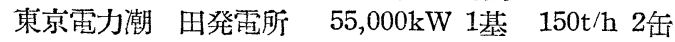
東京霄力鶴 見発電所 $66,000 \mathrm{~kW} 2$ 基 $300 \mathrm{t} / \mathrm{h} 2$ 缶 中部雷力名 港発雷所 $55,000 \mathrm{~kW} 1$ 基 $250 \mathrm{t} / \mathrm{h}$ 1缶 中匡電力小野田発電所 $35,000 \mathrm{~kW}$ 1基 $\quad 160 \mathrm{t} / \mathrm{h}$ 1缶 九州電力相 浦発電所 $55,000 \mathrm{~kW} \mathrm{1} 1$ 基 $170 \mathrm{t} / \mathrm{h} 1$ 年 九州電力筑 上発電所 $55,000 \mathrm{~kW} 1$ 基 $140 \mathrm{t} / \mathrm{h} 3$ 缶

\{3\} 前記の(1)，(2)項は既設の発電所の唔强または拡張 であるかっざらに出力 $66,000 \mathrm{~kW}$ または $75,000 \mathrm{~kW}$ 級の大型プラントの計画か，既設発電所とは别個に 淮行されている。

この計画には,蒸汽圧力, 溫度とも従来よりさらに一 段そ高く,タービン入口に拮いて圧力 88 $102 \mathrm{~kg} / \mathrm{cm}^{2}$, 溫蒦 $510 \sim 538^{\circ} \mathrm{C}$ 級の最新式設計を探用すべく检討中 のものか岁る。ここに註目に価するのは，第(2)項に記 远した大型ホイラはそのすへてか圧力 $65 \mathrm{~kg} / \mathrm{cm}^{2}$, 温 度 $485^{\circ} \mathrm{C}$ 級の高圧高溫ホイラてあつて, 本邦におい てもこの程度の圧力, 溫度昿く探用されて来たこと

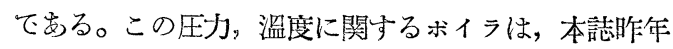
3 月号に紹介された九州電力築上発雪所の $1 ， 2$ 号缶

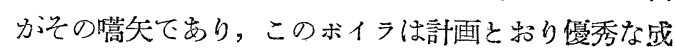
績て渾枟を継続し，九州地方の電力共給に多人の貢献 をなしつつある。

第(1)項に記迹した尼ケ崎第 II 発電所の堙設の 200t/ $\mathrm{h}$ ホイラ 2 缶には, 撚整方式としてわか帼最初のタン ゼンシャルハーナか探用されているか，これの揮転成 績は斯界の注目するところとなつている。タンゼンシ ヤルバーナは米国て開発されてその成縝の優秀性起記

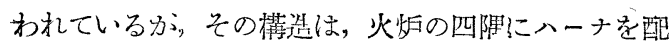

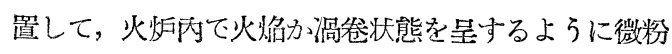
炭と空気とを噴出させるバーナでつて，微枌炭の完 全燃燒には至極適当した構造てある。むたバーナの欣 込角度を上下に動かすことによつて過熱蒸汽の温度を 意のままに調節てきるといら特微がある。

第(2)項に記政した名港発電所の $250 \mathrm{t} / \mathrm{h}$ ホイラは従 来本邦て最大容量てあつた $200 \mathrm{t} / \mathrm{h}$ を瑹驾するもので,

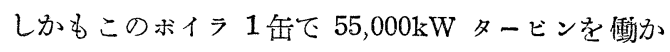
すいわゆる 1 機 1 缶式の本邦最初の試みであり。また 鹤見発雷所の $300 \mathrm{t} / \mathrm{h}$ ポイラは $66,000 \mathrm{~kW}$ ターヒンに

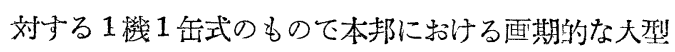
ホイラてある。さらに鶴見発雷所 $300 \mathrm{t} / \mathrm{h}$ ホイラには
前迹のタンゼンンャルハーナカ探用されるほかに，微 粉炭裝置として人型の新型レーモンドミルか使われる ことになつている。このレーモントミルはきわめて跖 新な設計のものてあるか，これとタンセンシャルハー ナとの組合せはこれまた本邦最初のことてもあるの て，その成緽には多大の注目か註かれている。

\section{工業用竅炸と焚燒法の趨勢}

\section{I 鉄鋼関 係}

昨年（昭和27年）1ケ年をふり返つて，鉄鋼業にお

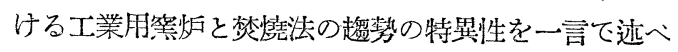
れは，重油燃燒の分野力洛炬について浸透拡人し，在 来の発生炬力 $丆$ 焚炉，むるいは石炭焚炬力はなはたし

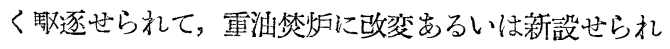
たことにあつたといつてよい。けたし，本年度は，重油 の供給か潤六でりりこれに反して石炭の単価は高腾 し, 単位熱量 $1 \mathrm{Ca}$ 当り重㹨分比較的割安に当ると同 時に, その燃燒と取报いにようやく熟烓し, 調節, 荤 搬，灰捨，効率な々の諸点から女，その安易さと便利 さによつて，経成上その燃料代価以外のプラスを感得 したためにほかにならない。るちろん非常時，むるい はわか国將来に抢ける燃料対策といらたような大きな

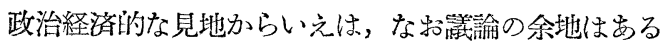
であろらか，現害の問題として，前記の割安の問題と 計量管理的な線より，將来にわたりますすす重油化は 促淮せられる倾向にある。各炬の重油化子同時に，当 然の㷌結として，重油の計量すなわち量と圧力と溫 度, 空気の討量 (量, 圧力, 溫度, 比率) 抢よひ燃炶 自動調筇力溌達した。これは，石炭あるいは発生炬が スては，その物理的生質上から計測か困踓て，計量管 理の限鹿に達していたからてもる。鉄屚一貫メーカー に特いては，熔鉱师がス、コークス炬ガスを有する関 係上，重油はガスとの混燒さたは炭化に使用して成績 を挙げた程度にととまるか，鉄鈮平炉メーカーに括い ては, 事情の許すかきり，從来の発生师ガス加熱の本 炉を重油加熱に転換，あるいは改筑した。これによつ

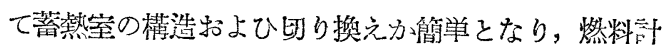
量と調節の容易性からさらに進して自動制御方式を㟫 用するものも生じた。空気の供給は多く强制通風に改

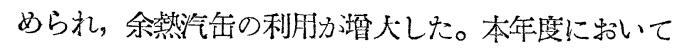
は, 平炬々內のプラス操業と計器による作業は普遍化 して，もは中常識化しな感がる。煙逪ダンパーの自 動调節は最子多く用いられ，炬內を水杜 $\pm 1 \sim 2 \% m$ の 間に保持与る。次きに，空気と燃料の比率自動调節总: 用いられ，進んでさらに，火焰の溫度むるいは炊内穴 恕は天井の溫度を基凖として，これに応する然料を制 
御し，徒つて空気量就び所內压力を顺次総合的に自 動調節するいわゆる完全自動调節の設供を有するもの カ現われた。この傾向は漸次発展して行く形势にあ り，各製鋼所に执いて多く計画されつつある。䥠浴の 溫度を唤間的に正確に知るためにイマジョン・パイロ メーターを熔融鋼中にさし染み，溫度を自記すること によつて製鋼の作業を正確適正ならしめんとする方法 カ試みられて，卡れそれ成功を收めた。この方法は备

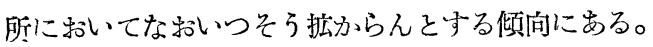
数個所の製鋼所に沶いて，平炬の前後壁，「昇り」並 びに蓄熱室の天井なとに，クロムマグネンアその他の

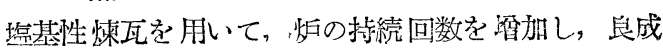
績を收めた。これがために，炬の天扑にむでクロム、 グネシア煉瓦を用いて炊の寿命を延辰し，䃍動率を燃 加して, 出鋼能力を唔加せんとする方向に進みつつあ る。既に外国においては，かかるォール・ヘーシ，ク (a11 basic) の炬は数多く用いられ，数年以上の径験 か活り，持続回数は 2,000 回以上に及吢という。酸素 製鋼を行つている製鋼所の成樍は，本年度出同様に好 成績て熔解恃間を 1 時間以上侸縮することは確実のよ

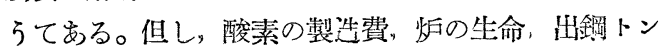
数なとの関倸をはつきり定めるにはな挂永続して研 究する要があ。酸素をコンハーターに使用せんとす る試みか計画されたが，この問題は来年度において主 要な問䅡となる可能性がある。

加䓡炬に重抽を使用寸ることは，径来の考えからい えは，鋼材の均一加熱上不可とされたものて岁るか バーナーおよび燃燒方法の改善工夫によつて，本年度

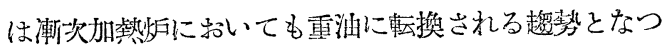
た。けたし，前远のごとく夜休燃料か取拔い上僬利な こと，調節の容易なために，特に炉內雾围気を重親す

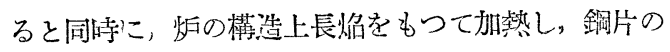
均一温度起得儿とする作業にとつては，最必適するも のとなつたのてある。このためにバーナーか発達し， 加熱輸邆なとの油の処理の裝置, 油の計量設備か発達 した。油の計量调節の簡易性から当然の㷌結として, 平炬について远へたと同じく，計量營理なよび自動调 節か盛しとなつた。特に，完全自動调節裝置心谱及し た。すなわち，釗片の溫度を基凖として重油の量を調 節し,アトマイズする蒸気の量, これを燃燒する空気 の量を調節し，ダンパーを開閉して炉內压を一定とす る総命的な完全自動てある。炬の型式は徒来のものと は著しく変形し，二層式山るいは三層式となり，加熱 扣よび均熱を充分に行う形となつた。これか，本年度に おける加熱师の特色てある。均熱艆については，本年
度において，多くは從来の型式を改妇，アメリカ式の 最新式均熱炬を輸入し，これを皎動した。もちろ儿， これには, 自動調節裝置並び計器頪一式か附属して いる。これを要するに 本年度に执いては，本炉，加

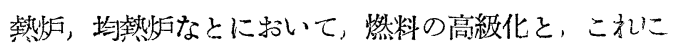
從つて各種の附属設備か溌達し, 各種の合理什設愑特 に計器堔業力溌展し，战の改築かこれに従つて行われ た。原単位は，本炬に款いて，製銅トン当り 120,000 ないし 140,000kcal，加熱炬において鋼片トン当り 300,000 300,000kcal, 均熱师において 10,000 200, 0 00kcal てむつたがここれは前年に比し著しい進步てあ つた。

\section{II 鉄鋼関係以外}

昭和 27 年度に抢ける鉄絧関係以外の工業案炉の焚燒 に関与る顕著な事実忠，石炭にかわつて重活燃料か人 巾に取り入れられたことてある。すなわち，不炭価格 の上昇，炭坑ストによる不炭需給のアン八ランス拉 ひ企業合理化施策の一環としての燃料コストの切下け なとのために，セメント，レンカ就よてカラス工業の

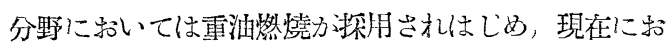
いても盛儿に切換えか進行中であるといらことてあ

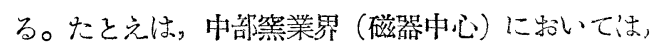
燃料費切下村刘策として角，丸空なとに重油燃燒老取 り入れて然成時間の余縮をみ，その結果コスト切下け

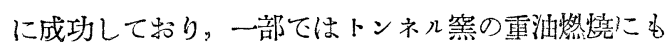
成功している。一方ガラス工業界においても, 発生炉

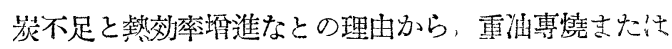
一部ガスとの湿绫を探用して生座能率の向上をみてい る。セメント工業界においても，一部てはロータリー キルンを全面的に重油燃燒への切換之を行つた。こと にセメント炬ては，徒来の微粉炭燃燒に比較して重洋 燃燒の場合には灰の生成なくっから溫度調節か谷易て あるのて品質の向上に利与るところ心人きい。

このように重油燃㭠か人巾に探入れられているか 重油燃然の正しい挩業方法，炬体レンカおよび製品に 蛙よに影貿なとについては今後人いに研究の余地か むる。特に重油は高 Cal 有するのて，これにとも なら溫度調䇺技術は炬の構浩そのものに関聯してくる ので,レンカの品質と相むつて, 炉の設計面から女重 油燃烓との闗聯性を考慮せねはならない。一方徒来の 不炭焚炬においては，從来一般硝子熔解坩堝炬におい ては中塊炭の手焚然燒を行つていたがこれにかわつ て押込通風を行い，投炭を適宜少量に加减士る乾溜焚 に成功している。これによると從来に比一燃料の消費 か人巾に減少すると共に，乾溜焚の際に生するクリン 
か人巾に减少すると共に，乾溜焚の際に生するクリン カーは深水により防止しらるので，何ら困䧼をともな わないことである。むた硝子竿においてター几湿燒に

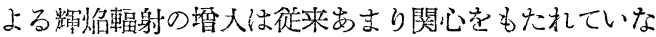
からたが，加熱時間の短縮と炸冈溫度分布の均一性の 哴いことか実際的に認められた。このほか，特殊な研 究成果としては，両焚式直焰空におけるくすへ瓦坴成

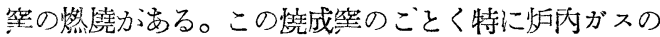

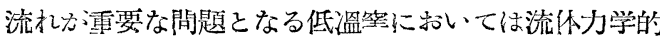
設計か可能であり，こ机について寺田氏のくわしい研 究発表か行われている。また沢井氏らは，ガラス等の 燃整の基礎研究として，モデル炉を使つてポート構选 とガス燃燒との関係を実験的に究明している。

一方外国に拈りるもとしては，人容量タンク䇪の 流体力学的抵抗に関与る研究がる。すなわち，從来 この種の等ては気休力学的抵抗，通風特性なとは普通 計算に考慮されていないかうここの研究はいろいろの圧 力損失, 正常なる溫度分布, 燃料消費拉よび抵抗減少方 法てついて線括的研究を行つている (L. I. Motorina 氏)。むた A. Garstang 氏心重油燃燒子実際の築炉 作業について重酒焚ガラス空の場合についてバーナ型 式および而火物の選択に関してくわしい研究を発表し ている。

また石灰セメントルレンガ括よびタイ几燒成に湿炭 ガ交使用与る研究多発表されている。すなわち，探 炭のままの泥炭をあらかじめ乾燥育成せすに直ちにガ ス化させ，これを空炕燃燒に使用するもので,これによ り燃料の節約灾大巾に行われている。さらに Norton 被の蓄熱式㝨成等に関与る研究もある。すなわちこれ

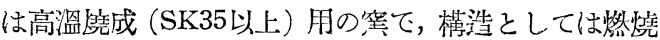

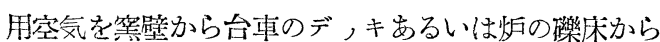
入れ予熱䘮行万型式のものである。空気の流入は 4 分 ごとに変向を行い，排ガス溫度は $200^{\circ} \mathrm{C}$ くらいの低 溫になりらる。これにより $1,750^{\circ} \mathrm{C}$ くらいの烓成溫度 カ得られている。

\section{固体燃燒に関する研究}

固体然料の燃缼の基碟的研究として人工黑猃なとの 炭素を用いてその反応機構を研究したものに，ます E. A Gulbransen 氏らは高度の低圧下て板状の黑敛 に気流を通じて酸化させ，その減少を微量天科で測定 乙精密度の高い化学的燃燒速度の結果を得て, さらに 反応機檴を理論的に検討している。炭素の酸化する湯 合の最初の反応生成物の問題については，J， R. Arthur 氏らか前報にひきつつき $\mathrm{CO}$ 生成の根拠と して炭素表面の焰について研究し，E. Wiche 氏方管
状炭素の燃燒てその集行過程中のガス成分よりこの說 を支持する結果を得ている。次ざに然料表面のガス ィルムを透しての拡散燃䍃の速度について J. M. Kuchta 氏らか河筒形炭素に高速気流を通して燃胙圭さ せ写顛による浿定結果より高速気流中の反応の機模を 検討し，一方本目英昌氏は不炭の燃燒を熱天科を沏、 て研究しその然跮機楛力固体炭素々暴り高級炭化水素 の燃燒と考えるべきてあることを示唆している。J. Chérean 氏熱天科て $100 \sim 270^{\circ} \mathrm{C}$ の低溫における 酸化を研究して不炭の巨人分子の二重結合に酸素力 固 定されるといら說を支持している。午の他固休燃料の

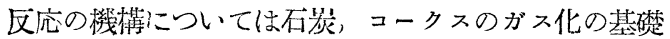
研究として数多く行われている。固体燃料の燃燒性の 試験として，J.A. Dulhunty 氏らは小型のポ，ト中

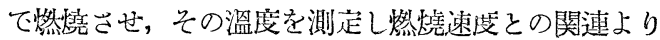
固体燃料の燃焢生の実験室的な詰験法を示しており，

E. A. C. Chamberlain 氏浊火炬輻射愋房用石炭の試 験法としてマントルビース型試験邱を用いて各種石炭 を同一紧件て燃して輻射熱を浿定し，その発生量子発

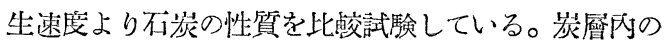
撚燒機構については M.W. Thring 氏方主として物 理的にこれを解粎し，R. Vaidyerwaren 氏らは，6in 径の燃烓ポ，卜を用いて Singareni 炭を用いて実験 をして着火および然烓速度の石炭粒度, 湿分, 空気量に よる影響を求めて鑜床ストーカに护る結果と刘比し ている。まケ作工業的試験としては，W. G. Markell 氏らははね込みストーカによる火格子上の燃燒機檴を 小型师を用いて炭層内の溫爱分布よりその然燒の過程 を推定しこ机を実際の然燒機のものに刘比してい る。むたきわめて実際的なしか必貴重な報告として Institute of Fuel の「工業に蚂ける灰とクリンカー について」なる綜說的郝告力诎て和り，この中て石炭

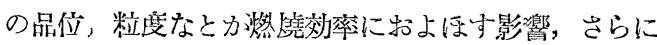
粗惡炭の驶用法，飛敞炭蝔なと広範围の実際の石炭焚 燒には問题となるきわめて多くの事例を引用して說明 している。

\section{選炭エ業の趨勢}

選炭の意義がすす近来変つてきた。肯は coal clean一 ing または coal dressing といらたか; 炭質き石炭 の有效利用の研究の面にも拡大され，备国共 coal preparation (石炭の調製) といら語に統一された。西 独やフランスの炭坑ては同一部課て選炭とコークスま たは性炭製造をやつている所か洺い。米国の炭坑地方 では Coal Preparation and Utilization といら会合 がはしは催され，選炭と石炭化学技術者か常に交歓 
している。かくして選炭と然料利用関係とはきわめて 緊密なのである。この趨势に当り本誌の「燃料関係事 項」中に新たに「選炭」の項を加えられんことはまこ とに侍期に適したことと思う。

すなわち選炭工業は天然の石炭を加工調製して，需 要先のおのおのの方面に最も適合したものとすること てあつて，焱坑と石炭消費者の間の直接の連鎻をなす 工業てある。

選炭工場の規模 小さい不完全な選炭工崵は石炭分 の損失も多く，污濁水の処理も困醮なのて，人見漠の 完備した中央洗炭工踢の建設か泄界的䞶勢であ。英 仏は1947年炭坑を国営にしたがこの方面に特に力を 注いている。各坑口の選炭虫簡単な穊分け作業にとと め，水選は中央工昜て処理するのである。北仏カレー 炭田の Mazingarbe 工晹は18の坑口より石炭を集め, 12,000t/日 の洗炭実績を示している。英国は從来洗炭 能力 $200 \mathrm{t} / \mathrm{h}$ 以上の工锡はなからたか, 国営以来 $300 \mathrm{t} /$ h 以上の工暘か続々新設されつつあり，その最大は Mosley Common 600t/h てある。米国て1950年操業 を開始した Pennsylvania 州の Vestaburg 洗炭湯の 能力 $2,400 \mathrm{t} / \mathrm{h}$ は性界最大であろ弓。ドイッは炭坑個 々に選炭工咀を持つか，ルール地方 400,000t/日の出 炭力約 150 の選炭工場て処理され，その不均 3,000t/ 日であつて，いすれもよく整備されている。

わか国の炭坑は，地形的に多くは䜪間に点在する関 係当むり，小さい選炭湯力擞多い。これては資金的に も技術上も無䭾か多いので，今後は共同あるいは合同 させてもつと集約さすことを考效はなるまい。

わか国ては三井砂川の $400 \mathrm{t} / \mathrm{h}$ 洗炭実績を示してい るのか㵊大の洗炭工場てあろう。

選炭機の種煩 最初中塊の機峨選別に㕸さつた水選 は，粉炭水選，微粉選別に伸び，さらに人塊の処理に 発展 しつつある。各国の選別機械璉類別の 設備現代 (設供能力 \%による) は第16表のとおりてある。

第 $16 \quad$ 表

選 炭 㙨 種 別

国 別 譇查年

$\begin{array}{lll}\text { 日 } & \text { 本 } & 1951 \\ \text { 西 } & \text { 独 } & 1951 \\ \text { 英 } & \text { 国 } & 1950 \\ \text { 米 } & \text { 国 } & 1949\end{array}$

\begin{tabular}{|c|c|c|c|}
\hline ジグ & $\begin{array}{ll}\text { 重 夜 } \\
\text { 造 }\end{array}$ & 桶 式 & 分級機 \\
\hline 853 & - & 92 & 15 \\
\hline 900 & 80 & 20 & - \\
\hline 676 & 68 & 80 & - \\
\hline 471 & 116 & 73 & 97 \\
\hline
\end{tabular}

ジグ 上表に見るごとく，選炭機としてジグは各国 とも圧倒的てあつて，現在はジグ選炭洔代といえる。 ジグにはその胍動を与える方法として，空気式とピス トン式とあり，欧州人陸ては徒来ビストン式か主てあ つたが，西独ては最近空気式力急潭している。英米日 ては人部分空気式であるジク洗炭が泇り普及した 事情は，原炭の品位形状の变化に対守る適応性か犬大 あり 大量処理に適するといら長所にあるがささらに 登石排出の自動阔整裝置が発明され，自動的に製品の 品位調整か浴易なことでる。ジグにて処理する石炭 の粒度は大体 $80 \mathrm{~mm}$ 以下であるか，最近のドイッの バウムジグは廃石排出点に空気室1個を加之, Hanza 炭玩ては $150 \mathrm{~mm}$ まて洗い, 三州芦別も種々工夫して $135 \mathrm{~mm}$ まて混洗に成功した。

重液選孷 石炭と溌石との中間比重の液体に原炭を 投じて浮沈選別をせは理想的てあることは明らかてを るかうこんな夜体は工業的にはなかなか得られないの て，高此重の固体の粉末を水に混じ懸濁夜を作る。こ の重液材として砂，磁鉄鉱，重晶石，黄鉄鉱，硫化鉱 燒㳯, 洗炭発石なとか用いられる。重液選炭の特長は，

\begin{tabular}{|c|c|c|c|c|c|}
\hline 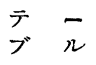 & $\begin{array}{l}\text { テーブル } \\
\text { シク混合 }\end{array}$ & 浮 選 & 乾 式 & その他 & 合 計 \\
\hline 03 & - & 02 & 00 & 35 & 100 \\
\hline- & - & - & - & - & 100 \\
\hline- & - & 16 & 133 & 27 & 1000 \\
\hline 26 & 22 & - & 84 & 混合 111 & 100 \\
\hline
\end{tabular}

選別精度かはなはだ高いこと，人塊まてもよく選炭し 得て手選労力を著しく節減し得ること，選別槽力小て 大きな能力を有しスペースをとらぬことなとてある か，次点としては細粒き微小粒の処理力困難である。 かくて欧米最近の大洗炭工湯は重夜選炭を主体として 200 10mm くららいの石炭を水選し，沺小粉をジグま たはレオ樋にて処理し， $200 \mathrm{~mm}$ 以上の人塊破碎し， 旧来の手選の労を廃止するのが趨勢である。前記の Vestaburg 括よび Masley Common 洗炭工湯もこ の方式による。なおドイッのフンホルト会社の重選機 は $1 \mathrm{~mm}$ まての小粒を選別している。

わか国においても $3 \sim 4$ 年来重夜選炭の研究力盛儿 でる。最初山形県田川炭嘊て，ついで夕張ては硫化 鉄烓障を重夜材として廃石より二号炭の回收を試み， 麻生山冈およで中鶴炭礦で中塊重選を開始した。山 內の重夜材には銅鍰を使用している，また三池三川礦 ては欧米にも全く類例のない独特の重材質を用いてい る。すなわち酸化鉆粉末をコムて固め $05 \mathrm{~mm}$ 立方の 粒とし，これに微粉炭を混じ懸濁夜走得て，小塊の重 選を実施する。以上の重選はいけれもその能力は20〜 
30t $/ \mathrm{h}$ 程度てあり, 試験的操業てあるか, 本格的なむ のとして，旧臘赵設を終つた三菱古賀山炭礦の重選 は能力 $100 \mathrm{t} / \mathrm{h}$ ， 米国 SWECO 会䓱製のドラム型選 別槽を備之重夜材には磁鉄鉣粉を用い，その回收には American Cyanamıd 会社の特許法を探用し，卡の 成果倠目也られる。

微枌の選炭 油浮選に上る微粉の選炭か, 戦後わか: 炭坑界に急に普及したした。北九州ては戶須式力数多 く設置されたか，金属山に好評なファーレンワルト型 か松島，夕張なとに設置された。

三井芦別に昨年輸入された Denver Sub-A は選槽 の側面より精炭を缢流させ，石炭用に設計されたもの てあつて，この式の 56 in $\times 56$ in 型は現に米英に広く 恢用されている。石炭用浮選機は人型を用い，槽数索 少なくする趨勢にある。その最も大型はオランダ国営 炭坑の Kleinbentink 式の直径 $24 \mathrm{~m}$ の円型槽 5 個 を1組として渾転するものてあろら。この Manrits 炭坑の $1,700 t$ /日 の祍選設供は世界最大のものと思わ れる。

ドィッの Reerink 博士発期の PU 法 (Coverto1

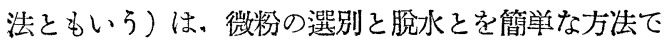
一挙に達成するといら巧妙な方法でつて，今後の工 業化か刮目せられる。

石炭綜合研究所長贱扑一宸氏は本法のわか国におけ る実施に直接関与している。

オランダ国営炭坑て発明された湿式サイクロンによ る微枌の選別々濃縮は，戦後各国の注目を浴び，欧米 にても広く実用化されている。わふ泪ても昭和25年以 来各所て研究され，現に相当実用化された。三池，山 內ては重夜材の回收用に利用し, 油户，上芦別，三井 田川，岳下ては哹選給鉱の濃縮用に供し，むた微㸮炭 中の尼分を减しその品位向上用に用いている炭坑は数 多い。発明元 オランダては磁鉄鉱未要重夜材として 10〜1mm 炭の選別に成功している。

手選軽減法としての碎㞸機 わか国ては，坑內より 座出する石炭中の人塊部分には，多量のホタや二号炭 を混有する坑力栘く，その場合手選々別に多人の労力 を要しまた径来の破碎機て破碎すれは水選原炭の可 選性か著しく不利となる。ゆ之に石炭とホタとの硬さ の差かあれはそれを利用し。衝擎的に破碎し，ホタに 附着した石炭分を落し，ホタを過度に破碎しない方 法を講じたいとして、ブラ,ドフォー1破碎機か想起 された。これは最初鹿町炭礛て探用され，つついて二 瀨䅨筑坑に据付けられ，相当普及しつつある。本機は 落下破碎式なため機械力巨大となり動力多く要する
のて、これを衝擊反撥式に改めたトィッの Prall Muhle に相当する破碎機か，前記浅井一彥氏により 唱導され，その陚作機力近く三井砂川にて実験される こととなつた。

振動節 わか選炭技術て從前劣つていたものに笠が ある。選炭技術の向上には優秀な笠がせとも必要で ある。戦後米国技術の示唆を受け, わか国にもタイロ ノク型やローへ，1型の良い振動䇻か製造されるよう になつた。しかし高能力の振動節はいまた国艮ではむ つかしいのて,三池三川坑には 300t/h に穊分ける Allis Chalmers 製 Rip1 Flo 笠を設置 した。また細粒を岵式にて軽快に節らため，三井田川 てはフランスより Sinex 穊を輸入し，煽石細粉を節 分けている。またトイッの Resonanz Schwingsieb は高能力な節として住目すへきであろう。

選炭機械類の最近の発羍ならびに趨势の大様は上上 のことくてあるか，わか、選炭技融の最近の発幸に大い に奇与しつつあるものとして，然料研究所第 5 郆か一 昨年 4 月発足したことを記憶すへきでる。同部は設 供いまた整わす，研究成果は今後の問題てあるか，專

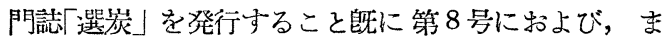
た全国選炭大会を，第 1 回福岡にて一昨年11月に，第 2 回札䖧にて昨年 6 月に開催した。いすれる約 400 名 の技術者か全国より参集するといら盛会ですつて，大 会後の選炭現場見学とその检討会なとと相むち，今後 のわか技術の進展の原動力ともなることか期待され る。

な特日本鉱業会選鈸專門委員会は東人山口吉郎呚授 を委員長とし，しはしは会合を重ね，全国の主要鉱山

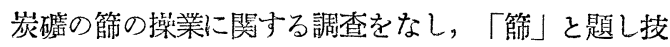
衍諿書第9輯として発行した。また, 戦後導入された 新選鉱機械に関する调查をるとめ, 目下刊行の隼備中 てあつて，その中には炭坑の湿式サイクロンか鉴けら れている。こ北らの調查畫はわか選炭工業の最近の状 況の一端を知るに便利てある。

\section{潠炭に関する研究}

選炭に関する研究は諸外国においてますます盛しで あるか,わか国においても最近 1,2 年間に急激に関心 か高まり。特に昨年度においては各学会誌 技術会誌 なとに発表された研究および報告は今まてにない活況 を呈している。これらの中て重要なものについて項目 別に埒げると、ますへウムシクに関する研究は依然と して盛んて，児玉凡のシグの理論に関する研究，秦氏 の水䢒機による比重分離の実体についてがすり，矢の 他, 花田氏の八ウム水槽內の摇動によつて生する力に 
ついて，千田，花田両氏の八ウム水選機診断なとの研 究がり，黑田氏はジグに関する所見を迅べている。 実際操業面ては水選機の取扱粒度の拡入乃試みられ， 三井芦別の粒度 $130 \mathrm{~mm}$ の処理について報告があ。 次きに重液選炭に関する研究ては，諸外国の注目すべ きものを挙げると, H. J.Daniels, H.Davis 兩氏はジ ニアル重液選炭法を発表し重選系統の簡略化を試み, J Griffen 氏はトロンプ重液選炭法の特色を明論し， また J. Baudry 氏は汾炭の重夜選炭を試み從来の重 選機により最小粒度 $1 \mathrm{~mm}$ まて処理可能てあると論じ ている。その他サイモンス・カーブス重夜巽炭機か新 型機として紹介された。わ方国に扮いては，基礎的研 究ては麻生 (欣) 氏の鍍懸濁夜による干步沈降の研究 かあり，工業化試験ては古池氏の特殊コム粒を媒作と する重夜選炭法の研究か特色かある。な㭽生 (典) 氏の山内炭鉱の重選実施について，船津氏の中鹤炭鉱 の重茌選炭, 山岡, 四方両氏の夕張礦に怙ける重夜選 炭なとの諸報告がる。浮游選炭に関しては，T M. Morris 氏の浮選機に猢る滞留時間の測定, Shou-

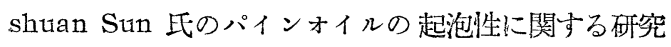
分㐫り,G. S Harlan, R. H. Ruddy 両氏は浮游選炭 に関してあらゆる角度から全没的に諭說している。国 內に挅いては娍氏の石炭の浮游生に関与る研究 真島 氏のメニスカスの高さよりする接触角の制定について の基礎的研究，佐々木氏の源游選炭による石炭組織成 分の分離に関する研究かなされ，実際操業面ては酒井

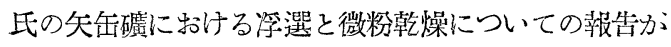
ある。微粉処理に関しては, 外国てはD W Gillmore, C C Wright 両氏の微粉炭の含有水分の特性に関寸 る基礎的研究, D A Dahistorm 氏の湿式サイクロ ンに高圧水を添加したときの高能率ディスライミング の実験かなされ，一方わか国に就いては微粉回收の重 要性力認識されて微粉炭研究委員会力組織され，べ， 一槽，沈澱池七トリングコーン, シックナ, サイ クロン，学巽丢なとによる回收法か研究检討された。 サイクロンに関する研究は最も活潑て山中氏の水洗廃 水よりの微粉炭の回收，深井氏の微粉炭回收用ッイク ロンの試験について，丹诋方娍鉱業所に怙けるッ イクロン，備酒氏のサイクロンと学選実施状況等の郝 告かある。またドィッて発展したPU法かわか国に紹 介され注目を浴び，佐々木氏の PU 法に上る沈澱微粉 炭の脫灰脫水の研究かある。微㸮の乾燥に関して丹 野，佐々木兩氏のフラ,シュドラインク法による石炭 の畭燥研究が㐫り, 破猝に関しては酒井氏のブラ，ド フォートブレーカの報告かある。また新型衝擊式粉碎
機かはじめてわか国に紹介された。選炭効率および品 質色理に関する研究は最近数年間に著しく発展した が，Ｏ R. Lyons 氏は各型の選炭機による選炭効率 の優劣を統計的に研究し，その他 P. G Meerman, J. M H. Bechers 両氏の分布曲線の精度, M R. Geer 氏の選炭成績を予知寸る方法，N M Potter 氏 の選炭における品質管理等の研究かあり，わか国ては 伝法氏の選炭に扔ける分離点祘よび分離誤善の定義並 てに分離靕度判定に関する提案かなされ，北氏の選炭

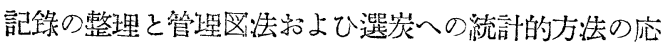
用，長屋，唒田両氏の茅沼選炭工钧に話ける品質管

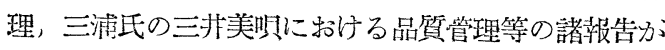
ある。一轧選炭に関寸る研究ては高桑, 小山雨氏の夕 張炭の特生の地域的差異に関与る選炭学的研究があ り，前田氏の現湯作業に跲ける洗炭口スの追求の研究 方㐫る。

\section{熱管理運動の趨勢}

27年度におけるわふ3国の熱管理連動外，前年10月の 熱管理法の施行を期としささらに一段と活潑となり

全国的に着々とその実續を收め，蜘料資源の保全と企 業の合理化の上に人なる貢献をしたものといいらる。 すなわち26年12月開会の国会における経戌安定本部長

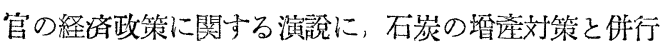
乙熱管理推進の必要性ふ强調され, 引続き，3月には，

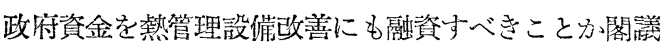
決定をみ，これに呼応して民間に䢺ける熱管理理動为 きわめて活況を呈したのでつた。

例年のと抢り 1 月より 3 月にわたる熱管理强調期間 においては，法に基つく指定 1,365工場において为 27 万t , 約16億内に上る節炭実綪艺收めた心，引続き 4 月より 6 月の 3 ケ月間に 21 万 の節炭成績を收めた。 熱管理士試験は 2 回，研修は東京，大阪拉よび四匡に おいて都合 6 回行われ，熱管理士の数も通算して6 228 名の多きに達し，本湩動の推淮力をなしている。

前に速へたと抢り，熱管理設備の改善に必要な資金 を日本開発銀行より融資する道の閉けたことは，関係 者の等しく渴望していたところてあつて，本渾動発展 に与える影響は甚人てある。通座局ては，本年度31件 (開銀融資期待額 72,100万可) を選定し閉銀侧に翰旋 要望を行つたかうこれによる年間節炭量は 8 万 $\mathrm{t}$ に達 するほとである。

工業技術院の行つている試験研究禣助金制度女，資 源の活用，企業の合理化に貢献する为のには重点かお かれ，本年度熱管理に関連吉了研究禣助金交付額 的 130 万円以上に達し，前記融資翰旋制度と相まつて熱 
管理推淮にはたす役割は少なくない。

工業技術院で，㪇管理指定工場の業種別特別調查 を前年に引続き実施したか，本年はセメント工業，鉱 山精镧業，ガス工業，化学肥料工業缺よび自家火力発 電所なと 125工場の調查か終了し，優秀工場の大臣表 彰、調楂結果の公表，研究発表会なとか行われた。中

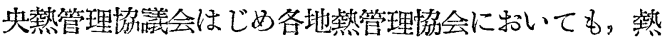
管理技術講演会, 各種講習会, 研究会, 見学会なとか; 活發に行われ，またわか国てはじめての試みとして 全国石炭分析技術コンクール開催のほか，熱管理便覽 その他資料の刊行なとか涊り，上記団体以外の方面て も，たと之は，東京，人阪，京都，埼玉なとの都道府 県の各種熹管理行事，大阪府拈よひ福島県熱管理協会 の発足，出版数社による熱管理参考書の刊行なと著し い活動の跡がられた。さらに，本年は，䓡管理中央 団体の强化の問題や，熱管理関速設備資材業者の連合 組織磪立なとの問題か盾険に取上げられてきたこと も本渾動のますすす重要なことを示す証左といらこ とかてきる。

\section{熱管理に関する研究}

第二次大戦直後, わ力国の石炭の産出以急激に减少 し，またその質的低下方著しかつた状態においてては， 低品位炭の燃燒か重要な問題となり，低品位炭の燃堏 方法に関して，種及の考案かなされ，それについて多 くの試験，研究力行われたのてあるか，昭和25年ころ より，石炭事情子徐々に正常の状態に回復してきた。 しかし，27年度においては，徒来わか国てはほとん々 石炭を使用していたボイラ，カス铍料を使用していた 䈇炬関係，その他広範囲にわたつて，重油燃燒に切り 替える傾向力著しくなつた。これは名ちろん，重油を

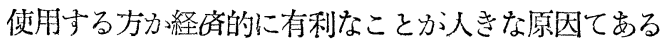
が，重油人手の見透しの関係より，炬に多少の改造を 加えて，重油バーナを取り付けるか，または，重㹨燃 燒を禣助的に併用するごとき方か多いようである。重 油燃燒に関しては，雜誌「熱管理」「燃料及燃然」な とに $2 ， 3$ の記事かあり，また日本機械学会ては，重 油燃堯に関寸る满演会（昭和27年 9 月）を催した。し かし，わか国ては徒来，重油燃然は一般に普及してお らす，特に石炭あるいはカス燃料と湿煏せしめること き方法については，今後实際上の試験，研究を重ねる 必要かあうう。

熱の有效利用，溌熱の回收なとに関する報告は，従 来より少ないのてあるかう，熱管理に関する研究とし て，令後さらに進めて行くへき問題の一つてあろら。 その一つとして，熱ポンプの利用は興味あるものて，
種々の利用方法か考えられるか，米国においては，熱 ポンプによる暖冷房は相当に普及し，雜誌「Refregerating Engeenering」には多くの報告かある。むた 䓡ポンプの原理による自已蒸汽圧縮式蒸発法は，わか 国においては，いまた試験的な段階てはあるが製㙁 に利用されよらとしている。これに関し，中條德三郎 氏「加圧式製璼法について」（日本機械学会誌 27 年 1 月）かあり，蒸発缶の重量就よで缺精算結果を記して ある。

工場に怙ける計測管理の必要性については，次第に

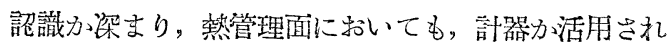
るようになつてきた。桑畑一彥氏「汽缶に数ける熱管 理計器の件月法」(熱管理，1952，2，3号) は，計 器の取付けおよび值用方法についてのよき参考資㸚と なろら。䓡管理計器の新しい問題として，今まて煙道 ガスの分析計としては，オルザート分析器以外は，ガ スの㷫伝導度，密度の性質を利用し，発カ ス中の $\mathrm{CO}_{2}$ を測定するものてあつたか， $\mathrm{O}_{2}$ ガスの帯磁率か他の ガスと著しく異る点を利用した磁気式 $\mathrm{O}_{2}$ ガス分析計 か咨用されるよらになつてきた。ある空気過剩率に刘 する $\mathrm{CO}_{2} \%$ は燃料の種顂によつて晎るか， $\mathrm{O}_{2} \%$ にれ

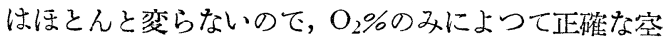
気過剩率か承められる。また電子管式自動平衡記镍裝 置は，彷来のものより一步前進したものて，工場用計 器として優れたものとい兄よら。わか国においても1, 2 の計器会趼て製作されているか，米国においては， 電位美計式拈よひ電橋式のものは電子管式に置き換元 られて，既に渐しい問題てはない上うてむる。以上の 計器については，窝內鉄也氏「最近の工業計器の動 向」（熱管理，1952，2，3号）に紹介か岕る。

発雷用の高溫，高圧汽缶に対して，給水処理の重要 なることは論をまなないか，低圧汽缶においては，從 来主に，㣫々の藏缶放を用いてきたか，これらに为給 水処理齐行万所か.多くなつたのはイォン交換樹脂の使 用による効果か大きいことによるものてあろう。野口 信彦氏「イォン交撸樹脂による給水処理について」 （燃料及燃燒27年 4 月号）にその解說かある。

\section{動力源の調查開発に関する情勢}

久しい間待望された大規模電源開発の問題力本年は いよいよその緒につきはしぬた。

何と言つも，一番大きな問題は，7月末電源開発促 淮法加国会を通過したことてあろら。この法律によれ は電源開発の場合最も大きな阻害要因となつている各 種の権盆の調整は新しく調整審議会を設けて処理する ことになつており，まな私企業てある電力会证ては開 
発困難な大規谟地点に刘しては，低金利の国家資金を

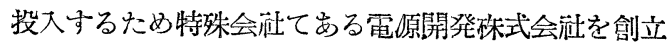
することになつている。

次きに着目すへき事項は，㲘案の外資導入の問題に からんて世界銀行調查団一行の来訪てあろ万。るちろ ん調查刘象は日本国内の各種の事業てあつたか，主目 的は電原開発の調查にあつたよらてある。

これよりさき本年春には昭和26年に来訪したアメリ カの O C I の正式な報告文か届けられており, こ らした調查を通して日本の電力問題の認識は相当徽底 していたのてある。

電気事業者より世界銀行調查団に提出された報交に よると, 昭和 28 年から 5 年間に水火力合計約 628 万 $\mathrm{kW}$ の出力潭を見込み，所要資金は逛变電を含み 1 兆800 億円，昭和 32 年度には需要に対して約 $5 \%$ 供給力か上 超ることになつている。

なお，電気事業界において本年特記すへき事項は， 公盆事業委員会か 7 月末廃止されたこと，9月から12 月まて長期間にわたり電原ストか行われ。このためい ろいろな斟会問題を起したといらことでる。

さて，本年中に完成した発電所数とその最大出力は 次きのことくてある。

$\begin{array}{rrrrr} & \text { 電気事業 } & \text { 自家 発 } & \text { 合 } & \text { 計 } \\ \text { 水力 } & 109(9) & 06(1) & 115(10) \\ \text { 火力 } & 36(3) & 47(18) & 83(21)\end{array}$

(単位 万kW，力，戸は発電所数)

地点として主なるのをあげると

水力・沼尺沼 (4 4)，三面川 (24)，平岡 (20)

火力. 名港 (21)，築上 (0 8), 西條 (0 7) 以上小

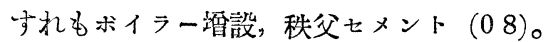

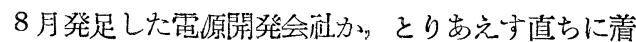
工寸るものとして発表した地点は，十勝川（4地点 157 ), 北上川 ( 2 地点 37 ), 天竜川 (佐久間 360 ), 庄川（御母衣 142 )，能野川 (2 地点 46 )。

懸案の只見川については東北電力の手により本流に 沿つて，上田，本名なとの地点か本年着工された。

火力については，築上に採用された高圧术イラに端 を発し，各低とも高塭高圧ボイラの新設計画か目立 ち，そのため将来計画においては火力発電量の潭加に もかかわらす，所要石炭量は漸减して行く倾向かみら れる。またこうしたホイラの輸入については外資の 導人加此較的容易なのて，相当期待か子てそらてあ る。なお，本年は重油消費力著しく多くつてきた。 ここ数年来冬期は異常豊水になれていたか，今冬は 珍しく渴水にみまわれている。こうして自然現像に庄
右されることなく冬ても電力に不足しない上らな年 は，電原開発会注の発足により抢它く数年の中に期 待てきるてあろう。

\section{地 熱 発電の動 向}

地熱発電についてはすてに本誌第31笑第 305号 (昭 和 27 年 8 月号, 技術タイシェスト $6 \mathrm{~A}$ ) において解說

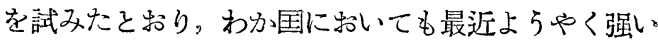
関心か备方面に沏いて払われるよらになつた。

以下，地熱発電について昭和 27 年中に䍩ける內外の 主なる動きについて簡単な報告を試みよう。

1 国内事情

A 工業技術院 工業技術院は昭和26年 7 月別府白 竜盗泉地区に約いて $30 \mathrm{~kW}$ の地䓡発電に成功したか， 昭和27年に扔いては同発電施設を九州電力制式会社に 贷与し，同䓑と協同して連続運転を行い腐蝕試験なと を行つた。な特，工業技衡院は地熱開発実験場に牱け る試験成績を中心として地熱発電に関する內外の資料 を集めて地熱発電武験研究報告第 1 集を昭和 27 年 3 月 刊行し，各方面の参考に供した。

B 機䑰試験所機诫試験所は上記工業技術院の試 験研究に協力して種々貴重なデータを提供したかっ，特 に同試験所山本技官は噴気孔内の蒸気の噴出状況を地 上から精密に测定与る特殊計器を案出して実験し，將 来の地熱発電閒発上重要な手段を提供した。從来，地 下より噴出与る天然蒸気かいかなる深さからいかなる 方向に向つてホーリングれ內噴出しているか不明て あつたか，同技官の計器を用いると相当倩密に地上か ら測定することかてきるようになつた。

C 地質調查所 地質調查所は大分県野矢およで大 岳地区の調查を完了したのて，昭和 27 年 2 月ころから 野矢地区に打いてテストホーリンクを行い，132m の 深度まて掘淮したふっ，都合により掘進を一時中止し た。

また，同調查所は鹿児島県霧島山拈よひ岩手県伙田 県八幡本の地熱调查を行引ほか，北海道地下資源調查

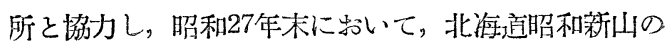
地熱調查を行つた。

D 北海道宁 北海道地下資源閭查所は，昭和27年 8 月, 地質調查所近藤技官, 東北大学渡辺万次郎敋授, 筆者らの来道を求め, 昭和噭山, 登別溫泉地区, ア上 サヌプリなとの概查を行い，さらに道費の追加予算党 計上して，昭和新山の地䓡調查を地質㒛查所と協同し て行つた。

E 長崎県 長崎県ては, 九州人学小田名誉敉授, 長崎県電力咕義会委員青木勇氏らに依啒して，雲仙小 
浜なとの概查を行つた。

F 富山県 富山県ても, 九州人学小由名誉敎授に よる概查，および地質調查所近藤技官による立山地犾 谷における慨查か行われた。

G 九州電力株式会证 九州電力ては，か称てから 地熱発電に関し强い関心を示し, 九州工業大学実藤敎 授 三菱造船筗式会注奧田克已氏らの協力を承めて九 州地方の地熱調查を行つて来たか, 昭和27年度には政 府神助全 600 万円を受け，自己資金 900 万円，計 1,500 万四の算て，大分県野矢（工業接術院の堀つたもの をさらに堀り進める）および大岳地区てテストホーリ ングを哏始した。

H. 利根ホーリンク跦式会证 終戦後、利根ホーーリ ングはいちはゃく地熱発電に着目，伊豆热川溫泉栿近 てボーリンク起行い, 名古屋人学小林明呚授の協力を 得て種々の害験をを行つたが，さらに營战辱鳴子盗泉 附近て 200本近くのホーリングを行い, 最近は强力な 噴気孔を得て小型機関車のエンチンを用い, $50 \mathrm{~kW}$ 侱 度の発電老行いホーリンク用電力に供している。

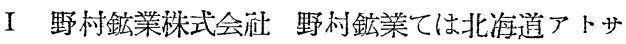
ヌプリて硫黄精練を行つているか，さらに近くの天然 蒸気を利用する目的てボーリンク昰する計画をたてて いる。

J 電㟲開発調查会 電愿開発調查会てb地熱発電 に强い関心を示し，学識経験者等をもつて委員会を組 織し, 調查研究を行つている。

2 海 外 事 声

世界唯一の地熱発電国, イタリーは現在約 30 万 $\mathrm{kW}$ の地熱発電施設を有するか，さらに每年 5 万 $\mathrm{kW}$ 程度 の拡張計画を実施して特り，また，最近はナポり附近 てもホーリンクを行つている。

イタリーの事情については同国から备種の交献資料 か邆られて来ているか，最近ては現地を視察する人か 相当ある。以下，同国を視察した方を紹介すれは次き のとおりてある。

九州電力火力䑙長 小山隆氏 F细発雷所長 後藤 重隆氏（昭和26年6月）

九州電力副任長 関本䝨一氏, 土木部次長 田代信 雄氏，火力部次長 古賀孝氏（昭和27年12月）

三菱造船陎式会社長崎造船所副所長 妹尾三郎氏 (27年 4 月)

三菱造船蛛式会社業務取締役 瀨田称生氏（28年 1 月)

日立製作所日立工場長 松野武一氏（27年 6 月）地 質調查所長 三土知芳氏 (27年 8 月)
また、ウェスティンク匡際電気会社 J G Rizzo 氏 はイタリーからの帰途, わか国へ立謇り, イタッー の地熱発電について関係者に報告かむつた。

以上のとおり，わか国に特ける地熱発電子いよいよ 実用化の時期力近つきつつあるものと考えられるに至 つている。

\section{原子门利用の䞨勢}

原子力を然料として利用するよらになると，とんな 点て有利かというと, 燃料消費量力異常に低いこと， 煙や有毒がスカ全く出ないこと，出力の割合か伸縮目 在て淍整し易いことなとか举げられるてあろろ。然料 の洒格はとらかというと, ウラニゥムわ梡全に消費さ れてる踼合にはその $11 b$ から得られる核分裂のェネル キは, 石炭 $1,000 \mathrm{t}$ 以上の然燒から得られるェネルキ に相当している。しかるに原子然料はトン当り 10,000 〜25,000 ドルて製造てきるようになつているのて，ト ン当り 10 ドルの石炭と比較して，発生熱量当りの価格 は石炭の 1,000 分の 1 あるいはそれ以下てある。実際 にはウラニウムか;全部有效に利用てきないてあろろ から然料費か石炭に比へて 1,000分の 1 てすむといら わけにはゆかないか，新しい燃料として充分経昘的に 利用てきる素質を持つていることは確かてある。

ウランウムは，前迅のように垔や有毒がスは出さな いか，人体に有害な種々の放射線を出和から，その防 護裝置に大変金かかかり，むた反応を效率的に行わせ るために，ウラニウム自身特よび，中性子の緩速㓮， 炉の構成材料等の純化に非常に手数を要すると思わ れ，また，方法次第てはウラニウム中の $U_{235}$ の檂度 を震くしないと反応からまく行わ机ないから，之の分 離に多額の金かかかつて,ランニングュストは安いか， イニシャルコストは相当高いるのになる特それが る。それがとらいう揢合になるかは現在のところ日 本ては見当か门かない。

原子力は最初は純学問的な問題として，原子核楛造 研究の副迶物として現われたものてあるか, それてかち ようと第二次大戦中てあつたために，その利用の面は 軍却て取りあけられ，兵器として発達した。彷つて， 当然発電に利用してよいと䍐わ机る原子炘の莫大な発 熹はたた川の水を溫めるたけて捨てられている。原子 炬は原子㷷彈原料のプルトニウムをつくるのに追われ て，熱の利用の方まて手か迴りかねているのか現状て ある。しかしこのもつたいない熱の浪費適当に利 用しようといら気琿に向つて，1951年の夏には米匡て 発雪用原子炊を民間資本て建設するとした場合の経成 的, 技術的可能性を研究させた結果，まる社てはプル 
トニウム生產策発電用の両用原子炬を政府資金でく り，生産されたプルトニウムを政府か買上げてくれれ は経阎的に成り立つとし，むたある社でそのよう なやり方は長い目て見て健全てない，よろしく発電專 用㗏殖后に進むべきてあるといら意見を持つに至つた ようでる。增殖炬といらのは，ウラニウムを原子炬 でつくな場合 1 個の $\mathrm{U}_{225}$ かこわれて出てきた中性 子によつて不活性な $\mathrm{U}_{238}$ の1個以上力㸮裂性を持つ た $\mathrm{Pu}_{<39}$ に転換されるというようなるのを指すのてあ る。

兵器としては，戦略目的に使用する原子喑彈のほか に，戦衍月的に使用与る小型原子爆彈や，原子施な? 分昨年中に完成したようてむる。るら一つ世界中を戦 慓させたものは米国て水素爆嘽の製造にある珵度の成 功を收めたことてある。これはウラニウムのように， 原子量の大きな核を分裂させて，その際発生するェネ ルキを利用する方式てはなく，水素核を結合させてい リウム核にする際に発生するェネルキを利用せんと卞 るものて，そのェネルキは分裂の際より为格段に大き いはかりてなく，とのよらに大きな煌彈にていつくれ るところに世界の恐怖加加つている。化学変化に結 合と分解分脑るように，核の反応に为結合と分解分脑 り，その兩方共に奏証された訳てある。

潜水艦に原子力ェンジンを据付けれは，一度子浮び 上らないて地球を 1 周も 2 周もでるのて恐るべき兵 器となる。米国ては昨年 6 月に世界最初の原子カェン ジン付の潜水艦ノーチラス号の起工式を行い,トルー マン人統領もその式に臨席したと郝せられた。この艦 用の原子力ェンジンはウェスチングハウス社て試作ざ れ，ほとんと完成したと伝穴られている。これとやや 型式を異にした潜水艦用原子力ェンジンがジェネラル エレクトリ，ク社でつくられているとも郝ぜられてい る。このような艦用のェンジンは, その経済性や，取 报いの簡易さか実証されれは，商船にも用いられ，ま た, プロペラのかわりに発電機责取りつけて，発電用 の原子カェンジンにも転換てきるからわれわれいと の成功に関心を抱いている次第でる。

航空機用原子力ェンジンは, プラ，トアンドホイ， トニイおよびジェネラルェレクトリ，ク両社か契約を 獲得したと伝元られ，この方面にも一步を潐めたこと は確実てある。

以上は米国の事情であるか，原子爆彈はり聯でも1 キリスでつくつたようて，米国と共に原子力利用の 先淮国とい穴るであろう。カナダとフランスの両国は 大䙺䄑な原子力生產をその本来の目的として，大きな
反応炬を動かしている。ノルウェーは小さい反応炉を 1 基所有し，スェーデンは現在 1 基を建造中である。 このほか, ベルキー、インド,フラジ諸国为区応炉 建設に関心を示し、オーストラリヤ。オランダ デン マーク,ドイッ, スイス, イタリーニュージーラ ンドなとては原子力について傎劍な研究か行われてい る。

日本ては, 原子力の研究について, 種々翊論がすつ て蜼行している上らてあるが，放射性アイントープを つくつて治㞠上なたは種々の研究用に使用与る目的を もつて，むるいは原子核の物理的研究を行万月的を名 つて，サイクロトロンの再建㖉てられている。その とれ子小さなものて，現在の世界の第一線の研究規模 には足許にも及はないはかりか，戦前に持つていたも のにすらはるかに及はないのは情ない。日本のような 䝱乏国でつても，やり方一つて何とでもなるのた が, 科学研究の重要性か, 理解て必ない朝野の指導者に より，科学政策かと机るはすはないのてある。

科研ては戦前 $200 \mathrm{t}$ のものと $23 \mathrm{t}$ のものと $2 つ$ つ ていたが終戦特米電によつて破壤されてしまつたの て，その後研究の自由か独立恢復と共に恢復されてか ら，残存部品をかき集めて23t の子の組立てつつあ る。こ机は 4 月には渾耺可能の子定て，主として寿命 の短い放射性アイントープをつくろらとするものであ る。

入阪大学拉よび京都大学でば原子核物理学研究の目 的で，それそれ，40 t 抢よび60 $\mathrm{t}$ のサイクロトロンを 計画しているし，東北人学てはべータトロンの製作を 計画しているようである。

日本てはま代まだこのようなありさむて，原子力の 工業的利用の方面に至つては全然方途方立なないあり さむでる。

\section{燃料に関する会合}

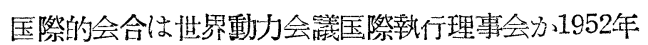
9 月 4 日よりシカコ市に扎いて17カ匡代表30名か诎席 して開催された。わか国より安川第五郎氏ほか 4 名か 参加し, 国際執行理事会副会長に A J. Alves de Souza 博士 (ブラジル), Gail. A. Hathaway 氏 (米国), Shri A. N. Khosla 氏 (印度) を選任し, 第 5 回世界動力会議经会を1956年フランスに预いて, 部会会翊を1958年カナダにおいて開催することを准決 した。

匡內に抢ける会合は，燃料協会においてては佳例の新 春特別譵演会を 1 月26日に開催したのをはじめ，3月 8 日は劣質炭の利用についての浅井一彥氏の特別講濱 
会，3月15日には日本化学会，有機命成化学協会と共 催てぺトロケミカルズに関する特別講演会，4月8日 より10日さて第15回コークス特別会，7月 2 日には日 本電気協会と共催て將来の雷力問題に関与る講演会， 11 月 8 日には然料協会創立 30 周年記念第20回人会加東 京人学工学部人請堂て開催され，11月25日より27日ま て第16回コークス特別会が幡製鉄所講堂において開 催された。

日本化学会第 5 年会は 4 月 4 日より 7 日むて東京人 学において開催され，また 9 月13日には橫浜商工会镁 所請堂において関東芰部々横浜商工会議所, 神奈川県 工業試験所後援のもとに石油に関する講演会また12 月20日には資源技術試験所と共催て川口において資源 化学に関する綜合講窝会乃開催された。

その他 3 月27，28，29日には明冶製菓講堂において タール工業50年記念講演会，技術研究会等開催され， 6 月 $21 ， 22 ， 23$ 日には北人眻堂において第 2 回全匡選 炭人会力資源技衍試験所，資源庁炭政局，札螑通栍局， 北诲道岩磺接術会の共催て行われ，11月25，26，27日 には工業技術研究発表会か日本経済新聞社ホールにお いて工羑技術院，東京通產局，日本経斉渐聞社共催て 開催された。

\section{燃料に関する規格}

昭和 27 年 1 月より 12 月むてに標隼会諩に竹いて議決 された日本工業䏹格（JIS）中，燃料に関係のある規 格をあけると次きのことくてある。

D1002 力 万発生炬付自動車走行試験方法

K1412 粒状活性炭

K1426 活性炭 (粉末)

M8512 酶火物原料の耐火宸試験方法

$\mathrm{K} 2405$ タール製品（タール墇基類）

$\mathrm{K} 2406$ タール製品（加工タール）

$\mathrm{K} 2407$ タール製品（ピ゙チ）

$\mathrm{K} 2201$ 工業がソリン

$\mathrm{K} 2202$ 自動車ガソリン

$\mathrm{K} 2252$ 石油製品反応試験方法

K2253 アーベルペンスキー引以点試検方法

K2254 カッリンおよび灯油分留試験方法

K2255 石油製品㦄蝕試験方法

K2256 アニリン点怙よび昆合アニリン点試験方法

K2257 工業用ガソリン斑コン試験方法

K2258 石油製品蒸気圧試験方法

K2259 オクタン洒測定試験方法

$\mathrm{K} 2260$ 加鉛ガソリン中の 4 ×チル祉定量武験方法

K2261 ガッリン中の実在ガム試験方法

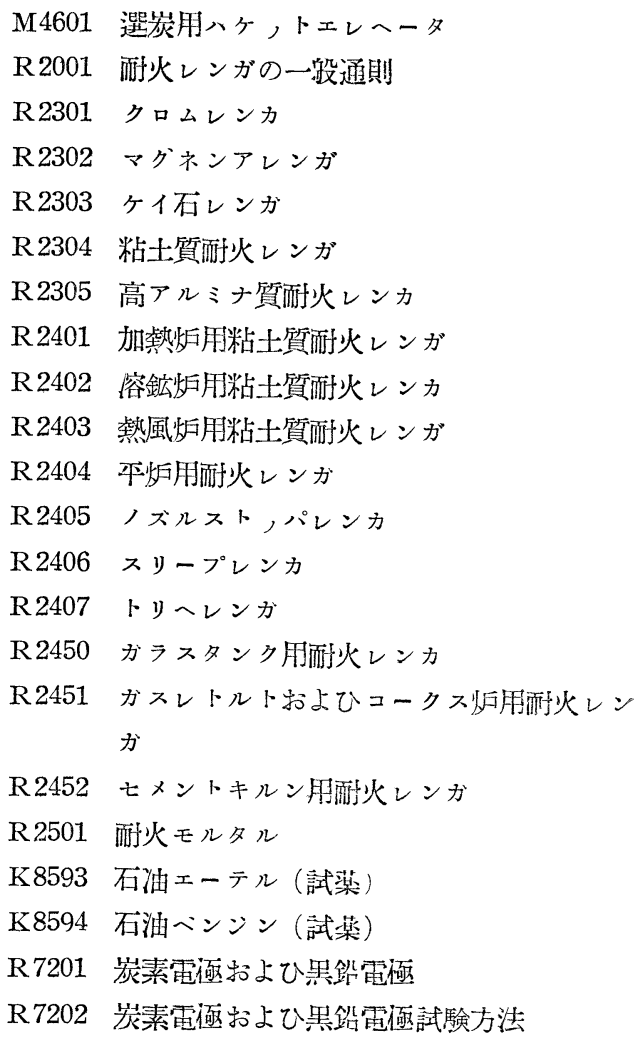

\section{縩料に関する新刊書}

昨年度に本邦において刊行あるいは紹介されれ㐬然料 関係刊行物の主なるものを列挙すれは次きのことくて ある。

山田復之助 鉱業経営と選鉱設 720 冈 朝倉書店

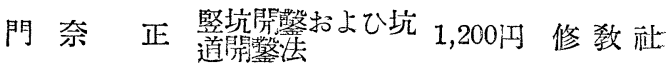
坡谷幸六鉱業工学

江淵藤彥運搬機的

中 野 奏 鉣山保安学

経斎安定本部 アメリカの炭磄事 訳啒

情

580 円 修敎社 320 円 修敎社 680内童業図書

具島陸雄探炭計画 (上) 350内 修呚社 田中, 喜多殽機工業化学下条850円 丸盖出版 日本瓦斯協会 ガス工業 (下卷) 1,200内 丸善出版 大山㓮吉宇部炭の性状・カ 850冈 コロナ社 舟 坂 渡 燃料试験法 管 原 管 雄 熱管理計算法 300内 压民科学 430冈 産業図書 勝石炭・石油・奖 290 日商工会馆 290 出版部。 
山內俊吉耐火物の研究450内技報堂 中央勢管理協 熱管理便覽 950内 丸善出版

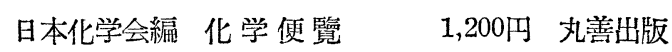

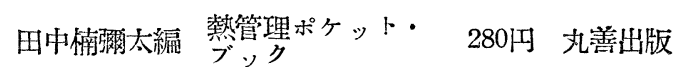
化学機械協会 最近の化学工学 380円 丸善出版

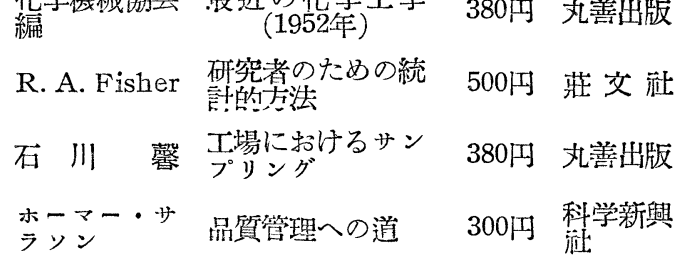
G. H. $Q$ 編 日本の鉣物資源 1,500 洼事通信

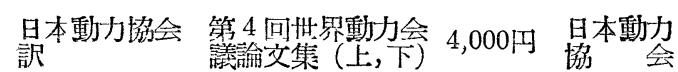
佐久間 昇訳 レッぺ反応 380 円 丸善出版

American Chemical Sosciety, Progress in Petrolem Techiology.

A. S. T. M. Special Comilation of Standards

Gaseous Fuels, Manual on Measurement and Sampling of Petroleum Engine Test Methods for Rating Fuels.

A. S. T. M. Special Technical Publications

Physical Constants of Hydrocarbons Boiling Below $350^{\circ} \mathrm{F}$.

A. S. T. M. Technical Symposiuns

Lubricants S. T. P. 88

Synthetic Lubricants. S. T. P. 77

T'urbine Oils S. T. P. 105 .

Bondi, A., The Physical Chemistry of Lubyicating Oil.

Bondi, A., Lubricating Oils.

Boone, L. P., The Petrolewn Dictionary.

Boone, L. P., Petroleum Industry.

Brauns, F. E., The Chemistry of Lignin.

Broida, V., Heat Inertia in Problems of Automatic Control of Temperature.

Burke, O. W. \& Others., Light Hydrocarbon Analysis.

Campbe11, J. R., Methods of Analysis of Fuels and Oils.

Cohen, H. \& Other Gas Twrbine Theory.

D,Alelis Fundamental Principles of Polymerization.

Davies, S. J. Heat Pumps and Thermal Compressors.

Emerich, H. Heating Design and Praetice.

Farkas, A. Physical Chomistry of the Hydrocarbons.
Farrington, G. H. Fundamentals of Antomatic Control.

Faust, F. H. \& Kaufman, G. T. Handbook of Oil Burning.

Friedel, R. A. \& Other Ultraviolet Spectra of Aromatic Compounds.

Foxwe11, G. E. The Efficient Use of Fruel.

Goldstein The Petroletim Chemicals.

Grierson Domestic Water Heating.

Gumz, Wm Gas Prodlucers and Blast Furnaces.

Hassler, W. Active Carbon.

Heiligenstaedt, W. Wärmetechnische Rechnningen für Industrieöfen Stahleisen-Bucher Bd 2.

Henning, F. Temperaturmessing.

Himus, G. W. Fuel T'esting. 2nd ed.

Himus, G. W. Element of F'uel T'echnology.

Interstate Oil Compact Commission. Engineer ing Committee. Oil and Gas Piodrction.

Johnson, A. J. Fuels and Combustion Handbook.

Kainer, Fr. Die Kohlenwasser stoff-Synthese nach Fischer-T'ropsch.

Kegel, K. Brileettierung der Braunkohle.

Kruschik, J. Die Gasturbine.

Ledinegg, M. Dampferzergung, Dampfkessel, $\mathrm{Fe}$ uerungen.

Lewis, B. \& von Elbe, G. Combustion, Flames and Explosions of Gases.

Mayor, Y. Combustibles Solides.

Mayor, Y. Combinstibles Liauides et Gaveus Naturel. Meyer, E. White Mineral Oil and Petroleum.

Reppe, W. Chemie und T'echnile der Acetylen-DruckRealtionen.

Royds, R. The Measurement and Control of T'emperature in Industry.

Sawyer, R. T. The Modern Gas Turbine.

Schwidt Fuel Oil Manual.

Smith, G. G. Gas Twrbines and Jet Propulsion.

Smith, M. L. \& Other F'uels and Combustion.

Spiers, H. M. Technical Data on Fieel.

Storch, H. H. \& Others The Fische-Tropsch and Related Syntheses.

Thring, M. W. The Science of Fllames and Furnaces. Winkler, H. J. V. Der Steinkohlenteer und Seine Aufarbeitung.

Zuidmae, H. H. Performance of Lubricating Oils. 